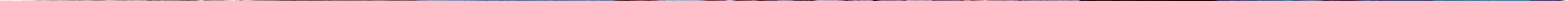




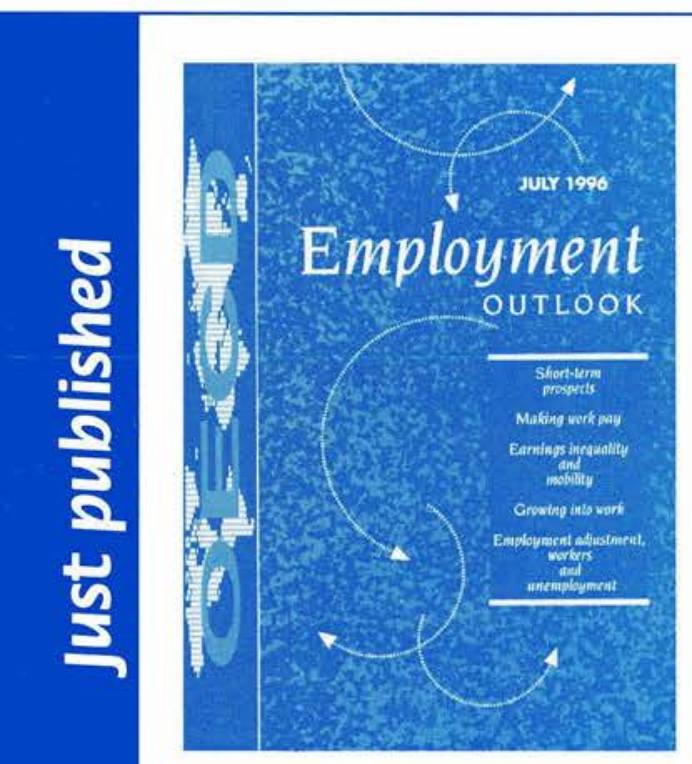

\section{Employment Dutlook}

This fourteenth edition of the Employment Outlook comes at a time when output growth in OECD economies has been weaker than expected. Although there is considerable variation across countries, employment in the OECD area as a whole grew by only $1 \%$ in 1995. Unemployment remains very high in most countries and in some it has recently been rising. Today, unemployment touches over $33 \frac{1}{2} 2$ million people throughout the OECD area.

This book outlines the prospects for the coming year and presents detailed analyses of important labour-market and social issues, including the interaction of tax and benefit systems with employment and unemployment, trends in earnings inequality, low pay and mobility, young people's transition from education to the labour market, and the extent of job- and labour-turnover and their impact on labour markets.

A Statistical Annex provides basic data on OECD labour markets.

(81 9608 1) ISBN 92-64-14900-7, July 1996, 212pp.

See pp. $49-52$ of this OECD Observer.

Price: FF305 US\$60 DM89 £39

\section{The OECD Jobs Strategy \\ Enhancing the Efiectiveness of Active Labour Market Policies}

Active labour-market policies are designed to assist the unemployed in successfully searching and applying for jobs. Spending public money for this purpose is generally considered to be more useful than providing only 'passive' income-support to the unemployed. But several studies suggest that many active labour-market programmes do not achieve their objectives.

How can active measures be made more efficient so as best to combat unemployment? Based on the recent history of active and passive labour-market policies in 12 OECD countries, this publication provides concrete proposals for improving public employment services and for co-ordinating unemployment-benefit measures and active labour-market policies.

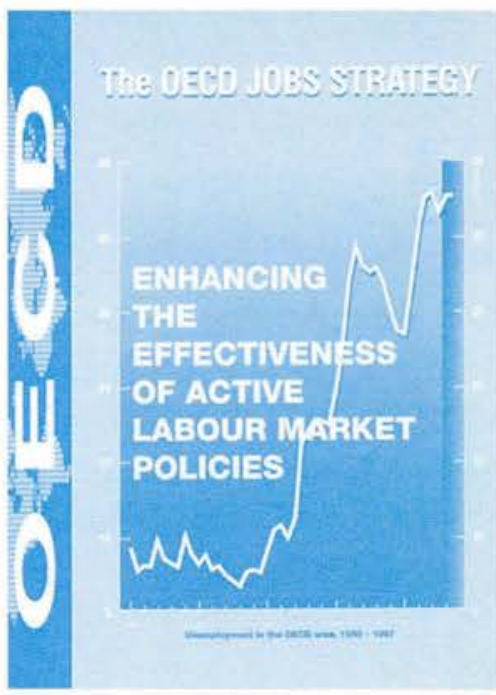

(81 9607 1) ISBN 92-64-14908-2, July 1996, 52pp. Price: FF65 US\$13 DM19 £8

\section{Territorial Indicators of Employment Focusing on Rural Development}

Territorial differences matter in international economic analyses. Territorial indicators on development conditions and trends are thus becoming indispensible. This report concentrates on regional labour-market and employment indicators. Its analytical focus is on rural development in the OECD area. It becomes obvious that, although the rurality (or urbanity) of a region is correlated with some employment features, it is not at all synonymous with a lack of prosperity or dynamism. There is a wide range of development patterns on each side of the rural-urban spectrum. A significant number of even the remote rural regions belong to the most dynamic parts of the OECD area - at least in terms of jobcreation.

(049608 1) ISBN 92-64-15276-8, September 1996, 170pp. Price: FF150 US\$30 DM44 Y3.200 


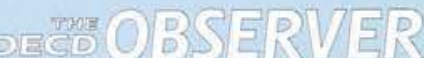

Published every two months in English and French by the ORGANISATION FOR ECONOMIC CO-OPERATION AND DEVELOPMENT

Editorial Address:

OECD Publications Service

Château de la Muette

2 rue André-Pascal

F 75775 PARIS CEDEX 16

Tel. (331) 45248200

Fax (331) 45241815

Internet Addresses:

Email:obs.mag@oecd.org

Web: http:/ wwww.oecd.org

\section{OECD 1996}

Applications for permission to reproduce

or translate all or parts of articles from

The OECD Observer.

should be addressed to

Head of Publications Service.

2 rue Andre-paseal.

75775 PARIS CEDEX 16, FRANCE

Reprinted and translated articles should

carry the credit line Reprinted from the

OECD Observer plus date of issue. Signed articles reprinted must bear the author's

name. Two voucher copies should be sent to the Fditor:

Signed articles express the opinions of the authors and do not necessarily represent the opinion of the OECD.

All correspondance should be addressed to the Editor:

The Organisation cannor be responsible for retuming unsolicited manuscripts.

Single copies:

FF30 - US\$6 - DM9 - $\{4$

Annual Subscription Rates:

FF145 - US\$30 - DM46 - \$20

Tel. (33 1) 49 104269

Fax (33 1) 49104276

Editor

Ulla Ranhall-Revner

Associate Editor

Martin Anderson

Assistants

Francoise Douaglin

Carol Thornton

Design

Codicom Bonté Divine!

Layout

Frédérique Bidaux

Photo Research

Silvia Thompson
Globalisation is cbanging intestment patterns, industria organisation and competitite conditions. These trends coincide with a grouing consensus that goternments ongh to concentrate on improting micro-economic efficiency

\section{Editorial}

Economy Equity and Efficiency: Towards a New Paradigm

Donald J. Johnston

$$
\text { Analysis }
$$

Investment

An Agreement on Investment

William $\mathrm{H}$. Witherell

Trade Labour Standards and Trade

Raymond Torres

Safe Products and Global Trade

Christopher Wagner

Industry Flexible Firms, Skills and Employment

Graham Vickery and Gregory Wurzburg

Do Tax-Incentives Promote Innovation?

Jean Guinet and Hiroko Kamata

Social Affairs Co-ordinating Services for Children at Risk

Peter Evans

Agriculture

The Transformation of Baltic Agriculture

Andrzej Kwiecinski and Vaclav Vojtech

Education The Internationalisation of Higher Education

Yu Kameoka

Educational and Career Guidance: What Works

Caroline St John-Brooks

Economy From Competition to Growth

Dirk Pilat

$$
\text { Spotlight }
$$

Economy Germany: The Welfare System

Eckhard Wurzel

\section{Observer Exclusive}

\begin{tabular}{lll}
\hline Economy & Indicators
\end{tabular}

For the Record

Employment The OECD Employment Outlook:

Countering the Risks of Labour-Market Exclusion

\section{Bookstore}

Just Published New OECD Publications



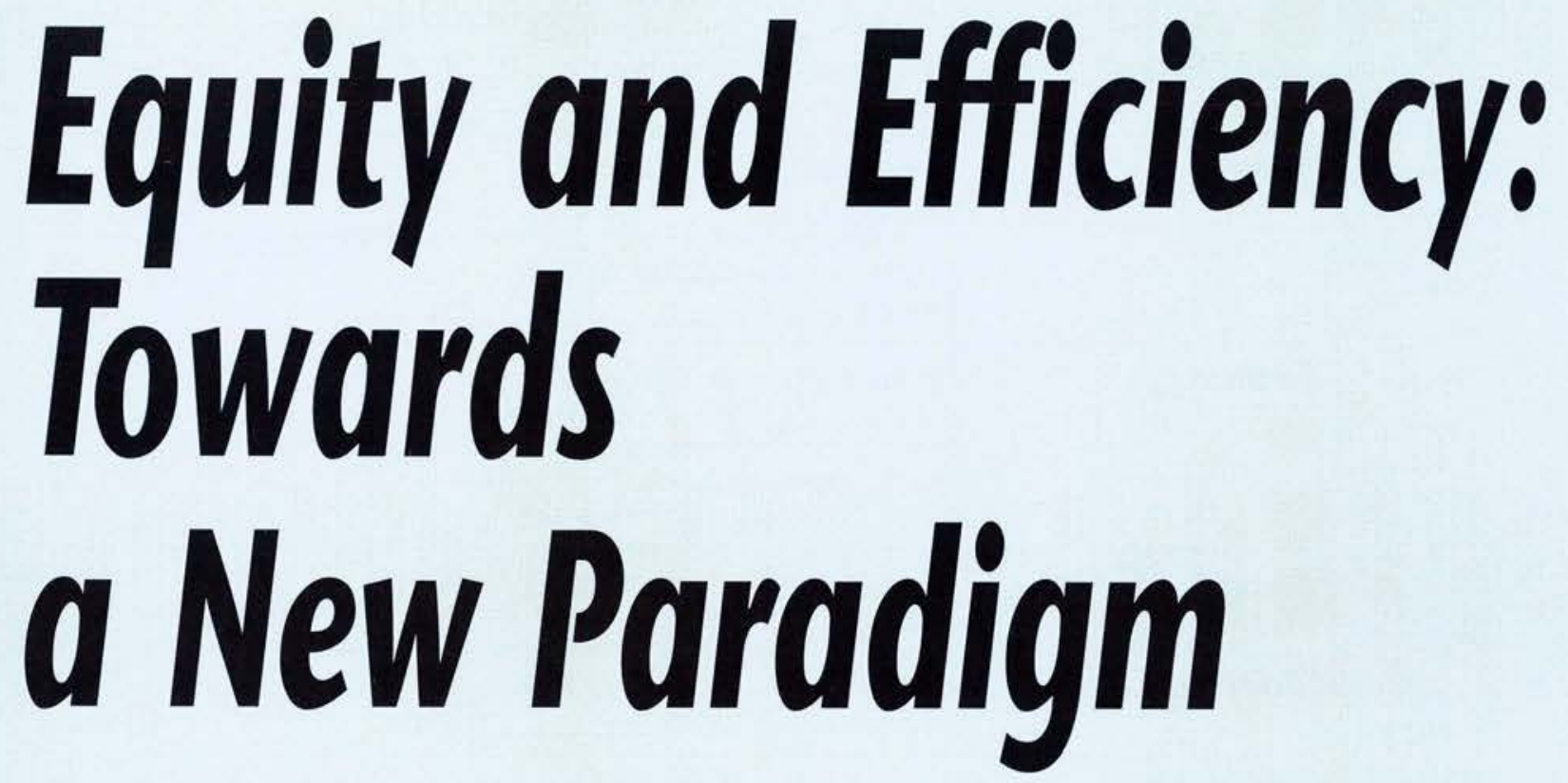

Donald J. Johnston, Secretary-General of the OECD

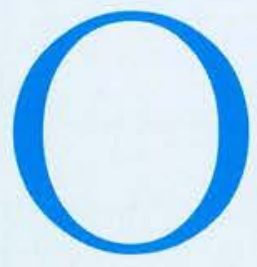

ver the last quarter-century or so the governments of the OECD countries have begun to look to an issue that occupied them less in the previous decades - how to improve microeconomic efficiency. That involves a range of topics: the organisation of the firm, international investment, competitive conditions, the functioning of markets and consumer satisfaction. All of these considerations raise a host of questions. What sorts of policies will increase efficiency? What are the benefits from improved micro-economic performance? How are they distributed?

These questions arise from major changes in the conception and role of government. In particular, there has been a shift back from the notion of the ever-expanding 'provident state' born in the after- math of the Second World War. At that time, governments of all persuasions were prepared to support the cradle-to-grave approach to welfare. A broad political consensus in all OECD countries aimed at providing generous education, health and retirement benefits to an ever larger number of citizens. There was a simultaneous consensus that macro-economic policy could manage aggregate demand and thus maintain full employment.

This consensus has been undermined by the extensive churning in the world economy since the oil crises of the 1970s. The business sector has globalised its operations, not least because the cost of communications, co-ordination and transport has plummeted. National economies have become more interdependent. The former confidence in the ability of government to manage economies by subtle fine- 
tuning of fiscal and monetary policy has evaporated and the role of the state has been brought into question.

The message of macro-economic policy is now about getting budget deficits back under control, which means reducing government spending if tax rates are not to go beyond what voters will permit, and using interest-rate policy to keep domestic economic activity from over-heating and fuelling inflation.

In spite of the ever-expanding pressure on social programmes in all OECD economies, the only direction for most government expenditures is down. The new consensus is typified by 'managerial' government policies which promise more value for money and more efficiency, while reducing waste and duplication, particularly in education, bealth and welfare.

Governments are increasingly looking to the business sector to provide many more services than in the past. Privatisation of a wide range of state-owned enterprises and services has been based on the notion that the market is more efficient in delivering results. Even sectors previously held to be 'natural monopolies' - infrastructure industries (transport and communications), personal services (education and bealth) and utilities (water; gas, electricity) - are being privatised, though often covered by some kind of regulation to prevent abuse by any resulting private-sector monopolies.

These notions have also extended to the running of government itself. The widespread practice of contracting-out within government departments shifts service-delivery from state agencies out to private-sector specialists. Such approaches are being used more and more in activities which are likely to remain in the government domain (defence, policing, national administration, economic policy and the like).

There is also increasing interest in improving the general climate for business. This is most evident in policies for industry and technology, where direct intervention (the provident state again, as far as business interests are concerned) has been replaced by broad, pro-competition policies designed to enable a larger number of firms to compete more vigorously in a larger number of markets. Here the unwritten concept is that a healthy business sector will benefit everyone.

But a broader dilemma looms. If the shift in policy has been towards increasing the efficiency of firms by liberalising competition and improving incentives for business to produce and invest, at home and abroad, there remains the problem of how to maintain equity, social cohesion and a reasonably fair distribution of income. As governments move away from being the 'provident state', other institutional mechanisms become necessary to provide the benefits that voters are used to, but appear politically unwilling or unable to pay for.

The pressing questions on the balance between micro-economic efficiency and broader social equity and welfare will endure. They are continuously addressed in the work of the OECD.

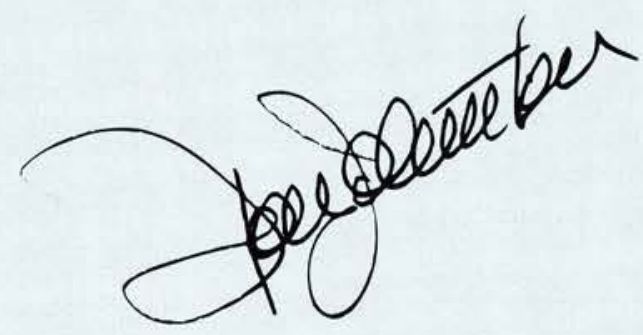




\section{An Agreement on Investment}

William H. Witherell

Almost a year-and-a-half has elapsed since the OECD ministers decided to launch negotiations among the member countries with the aim of reaching a Multilateral Agreement on Investment (MAI) by May 1997. The high-level 'MAI Negotiating Group', composed of senior investment-policy officials, has been meeting intensively since September 1995. A progress report to the Ministerial Council in May 1996 indicated that the negotiations are on course, most substantive issues have now been examined and a framework for the MAI is evolving. Much, of course, remains to be done. But what is the MAI, and how is it expected to fit into the overall framework for international trade and investment?

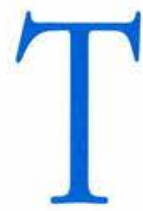

he time is ripe for developing multilateral rules of the game for international investment. The World Trade Organisation (WTO) manages a series of multilateral agreements for trade, but there is no similar framework for international investment. Instead, at present, companies making cross-border investments are confronted with a vast array of different legal frameworks as they consider where to invest. Although investment regimes have become much more open and welcoming in the recent past, there is no assurance that they will remain so in the years to come. Even in the OECD area, foreign investors still encounter barriers, discriminatory treatment and legal and regulatory uncertainties, Such remaining restrictions are a

William H. Witherell is Director of Financial, Fiscal and Enterprise Affairs at the OECD. potential source of international friction, not least because they are barriers to market access. Hence the interest in the Multilateral Agreement on Investment (MAI), now being negotiated at the OECD.

The goal of these negotiations is precisely to create a strong and comprehensive multilateral legal framework for foreign direct investment (FDI) among the participating countries. The MAI will reduce barriers to FDI and increase legal security for international investors. It will seek to 'level the playing field' by providing for national treatment - that is, by ensuring that foreign investors would receive the same treatment and advantages as domestic companies. To give teeth to the MAI, the intention is that it will be legally binding and contain effective provisions for settling disputes. It will, moreover, be a free-standing treaty open to all the OECD countries and the European Union (EU), and to accession by
non-OECD countries - which are being consulted as the negotiations progress (box, p. 8).

These objectives were re-affirmed in May 1996 by the OECD ministers, who further stated that the MAI should aim at achieving a higher level of liberalisation and to engage in an intensified dialogue with non-Member countries, in particular, those interested in acceding to the MAI'.

\section{Why Investment is Important}

FDI plays a central role in the process of globalisation, making it important for OECD and non-OECD countries alike. It can help upgrade productivity and competitiveness, bring transfers of technical and managerial expertise and facilitate integration into the rapidly changing international economy. Most OECD countries and a number of advanced non-OECD countries now export investment. Many are major hosts as well; and FDI inflows have likewise become more widely distributed in the OECD area.

The growth of FDI has accelerated. Preliminary estimates suggest that in 1995 inflows of FDI into the OECD countries advanced by a remarkable $50 \%$ while outflows grew by $40 \%$ ? Of course, overseas investment, particularly by the largest firms, is not a new phenomenon, but never before have so many firms from so many industries invested in so many countries. Firms increasingly view investment abroad as a business necessity, often with the aim of contesting markets more effectively. Often these investments have the effect of leading to increased trade flows as well, demonstrating that investment and trade flows interact in a complementary manner. And although investments directed towards or originating in non-OECD countries are increasing, the vast bulk of FDI originates within OECD countries and is destined for other markets within the OECD area - some $85 \%$ of all outflows and $65 \%$ of inflows in recent years. The MAl can thus be expected to cover a substantial share of the world's international investment.

The Uruguay Round did address some traderelated investment issues in the successfully concluded agreements on Trade-Related Investment 


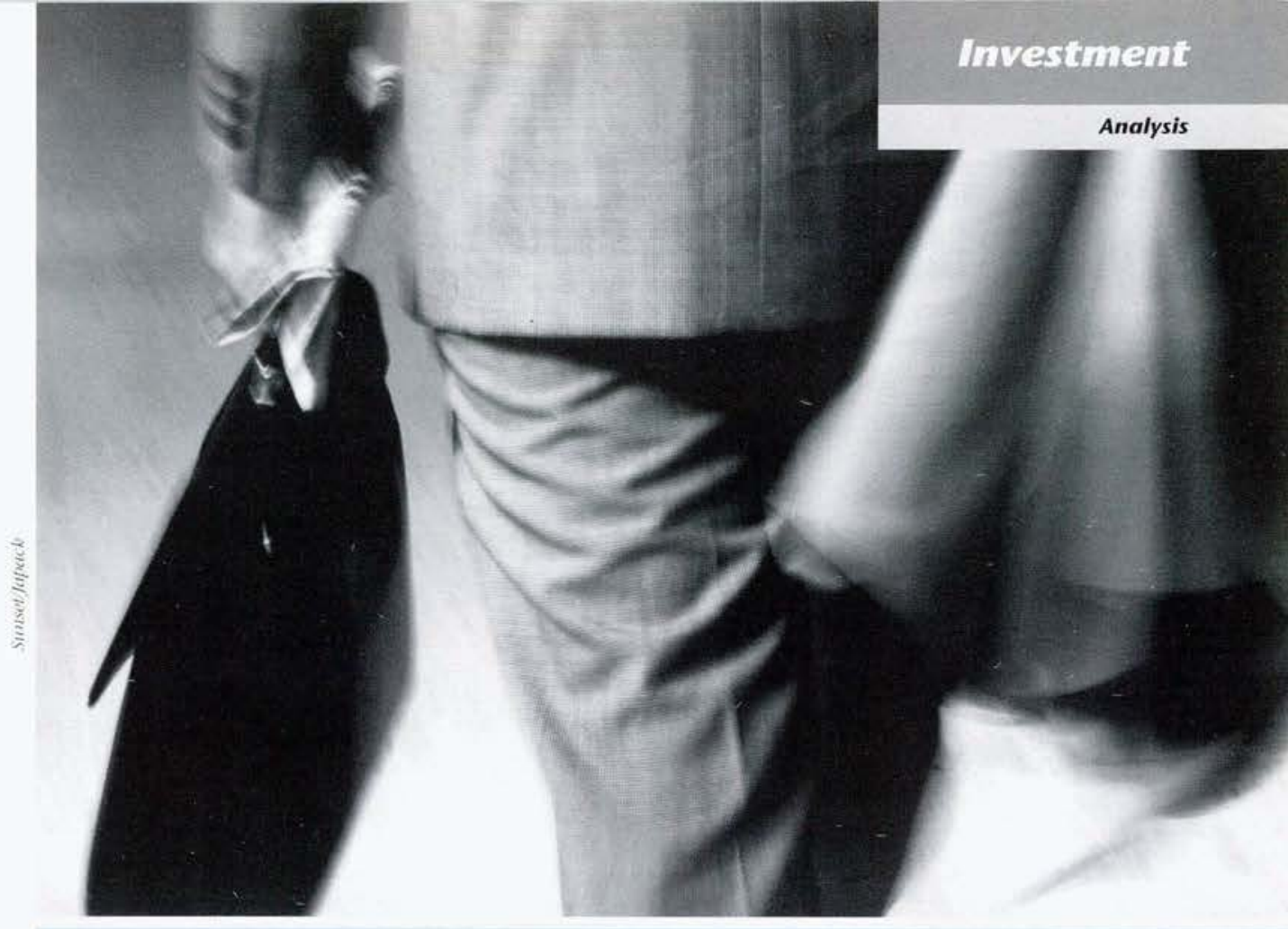
ments - the Declaration and Decisions on International Investment and Multinational Enterprises and the Codes of Liberalisation of Capital Movements and of Current Invisible Transactions. The healthy environment for investment which currently obtains owes much to these instruments and their implementation. They continue to be a force for liberalisation but, even taken together, do not constitute the comprehensive and fully binding multilateral agreement on investment that the OECD countries now believe is necessary.

So the principal motivation behind the MAI negotiations is to consolidate and improve these OECD disciplines by developing a comprehensive agreement, drawing also upon the strongest features of otherexisting investment agreements bilateral, regional, sectoral. Indeed, an important consideration behind the choice of the OECD as the forum for negotiations was the good prospect for concluding a high-standard, state-ofthe-art' agreement relatively rapidly among the member countries, building upon their past co-operation.

\section{Opening to non-OECD Countries}

Although the negotiations are taking place among the OECD countries and the European Union, it is important to emphasise that the MAI will be a free-standing treaty; that is, although the MAI is being negotiated in the OECD, it will not be an OECD instrument. Instead, it will be open to accession by interested non-OECD countries. Its implementation will not be the responsibility solely of the OECD countries but, jointly and equally, that of all the countries that eventually become a party to it.

Mobile investment means the transfer of technical and managerial expertise - a process which the MAI should facilitate.

Indeed, the OECD countries are committed to close consultation with interested non-member countries during the course of the negotiations. These discussions are being undertaken through a wide range of seminars, briefing sessions, and other informal contacts to provide information on the negotiations as they proceed and to hear and take into account the views of non-OECD countries.

But why would some non-OECD countries want to commit themselves to these international disciplines? The OECD's mandate is to develop an agreement that represents high standards in every respect, which may deter some countries but which should be attractive to those already committed to similarly high standards of treatment for foreign investors. Signing up to the MAI will indicate loudly and clearly to investors that the country concerned subscribes to the highest standards in market access, legal protection and equitable treatment, For countries that are also a source of outward investment, the MAI will offer the additional attraction of assuring market access and legal protection for investment into other countries party to the Agreement.

Non-OECD countries considering whether to accede will not be faced with a take it or leave it' situation. They will have had the opportunity to consult with the OECD countries during the negotiations. Moreover, any country seriously wishing to adhere to the MAI would be able to negotiate the conditions upon which it would become a party. That would not require re-opening negotiations on the text of the MAI itself but, rather, identifying any reservations the country would have to lodge to the various MAI provisions. Any reservations lodged by any party to the MAI would likely be subject to periodic review.

There are likely to be core conditions that all parties must meet - the provisions for protecting investments and settling disputes, for example, and a commitment to the basic underlying principles. But there might. by mutual agreement, be transition periods for some other provisions. For a country that would like to accede to the agreement but requires technical assistance to develop its investment regime, a programme for providing such advice could be developed, perhaps along the lines the OECD already is following with some of the formerly centrally planned economies.

Although it is hoped that eventually a good number of non-OECD countries will decide to accede to the MAI, participation is still likely to fall considerably short of the full membership of the WTO - currently 121 countries. At their meeting in May this year the OECD ministers affirmed their interest in beginning an examination of trade

1. Communique Meeting of the Council at Ministertal lezel Paris, 21-22 May 1996: Ministerial Communique The OECD Observer No. 200. June fuly 1996; and Donald I Jobinston. The Imperatice of Free Trade. The OECD Observer No. 201. Ausust/September 1996

2 Recent Thends in Foreign Dired Intestment, Financial Market Trends Dol. 6t, OECD Publications, Paris. Itune 1996

3 Introduction to the OECD Codes of Liberalisation of Capital Motements and Current Invisible Operations, OECD Publications. Paris, 1995: Code of Lib. eralisation of Capital Movements. OECDPuhlications. Paris 1995: OECD Declaration and Decisions on International Investment and Multinational Enter. prises. OECD Publications. Paris, 1992 


\section{An Agreement on Investment}

\section{FOCUS}

\section{The Evolving Framework of the Agreement}

After the first six negotiating sessions, the basic outlines of the Multilateral Agreement on Investment (MAI) are now evident.

\section{Definitions and Scope}

The definitions adopted for intestment and investors are vital in determining the scope of the MAI. The aim is to provide broad coverage through a comprebensive definition of investment and investors. Such a definition will cover tangible and intangible assets and apply to both before and after a foreign company has established itself in the bost country. Two conflicting desires bave to be reconciled: first, the definition should be broad enough to ensure that all relevant forms of imvestment undertaken by foreign investors enjoy the protection of the MAI; by contrast, it should not be so broad as to cover financial transactions which bave no connection to an investment. Further discussions are required to determine precisely where the line sbould be drawn.

\section{Investment Protection}

The Negotiating Group gave first priority to drafting a text incorporating bigh standards of investment protection, to be sure that investments receive fair and equitable treatment in the bost country as well as full and constant protection and security. This work proceeded rapidly because of the bigh degree of consensus among the OECD countries. The text now developed includes provisions on the general standard of treatment, compensation in the event of expro-

and investment in the WTO and working towards a consensus, perhaps including the possibility of negotiations. The word 'consensus' is particularly important, since the question of whether or not the WTO will eventually seek to develop its own disciplines in the investment area is a matter for the WTO membership as a whole to decide. If such negotiations were to be undertaken at some future date, it is reasonable to expect that the MAI would serve as a reference, as would priation. protection from strife, and the free transfer of funds. There remains only a few issues that require further discussion - whether: for example. serious balance of payments difficulties could be a ground for a temporary derogation from the obligation to ensure the free transfer of funds required or generated by an investment.

\section{The Treatment of Investors and Investment}

The MAI will incorporate disciplines cotering both the entry of investments and the treatment of foreign enterprises after they are established in bost countries. The principle of non-discrimination will be clearly the comer-stone of the MAI. In particular, it will be the national-treatment provisions of the MAI that assure foreign intestors non-discriminatory access to a sector and equitable treatment after they are established; this is the level plaving-field: There will also be provisions assuring most favoured nation (MFN) treatment and transparency. Further provisions will be developed to contain government measures which do not conform to the MAI obligations, to begin to eliminate them. and to list and subject to revieu country-specific reservations where such measures are maintained. All of these provisions will be essential to achieving the liberalisation objective of the MAI. It will probably be necessary to include certain general exceptions to the MAI's hasic obligations, as, for example, with measures taken for reasons of national security.

\section{Additional Disciplines}

In addition to these disciplines, which bave precedents in existing intemational agreements, the MAI negotiations are also breaking new ground and cotering a much wider range of investment than ever before, especially in questions of market access outside the services sector: Under discussion are, for example, kev personnel', provisions that would address the wish of international firms to be able freely to transfer or bire personnel to perform vital functions. Another example uould be possible provisions covering the participation of foreign investors in privatisation programmes. There are other examples in questions arising from performance requirements, monopolies and state enterprises, investment incentives and corporate practices.

\section{Dispute Settlement}

Most investment disputes that might arise under the MAI sbould be settled without recourse to formal procedures: accordingly, consultation arrangements to encourage amicable solutions are being developed. Nevertbeless, the credibility of the MAI will require that binding arbitration of disputes between states or between an imvestor and a participating government be available to ensure effective recourse in the event of breach of the agreement. The mechanism should be simple, clear, effective and efficient. A number of complex issues, including the appropriate scope of such procedures, still require discussion, but the outline of the mechanism for settling disputes is in an adianced state of development. other recent investment agreements such as the North American Free Trade Area, the Energy Charter, bilateral investment treaties and regional agreements among developing countries, But clearly, any IVTO agreement would have to be designed for the full WTO membership and in the framework of WTO disciplines and institutional arrangements. The WTO Secretariat is participating as an observer in the MAI negotiations to help avoid possible conflicts with the existing
WTO instruments. For similar reasons, observers from the IMF and the World Bank are also assisting in certain aspects of the negotiations

A fair amount of work remains before the details of the MAI become clear and a number of outstanding issues have yet to be resolved. In some cases, how to realise the aims of the negotiations still has to be determined - how best. 
for example, to achieve a reduction in existing restrictive measures, to apply the commitments of the MAI to all parties and at all layers of government, and to deal with measures taken in the context of regional organisations fostering economic integration.

Work is also beginning on the issues arising from the integration of the different elements developed so far. One difficult question is how to avoid potential frictions between MAI obligations and tax considerations. There are discussions on issues of extra-territoriality, such as conflicting requirements that investors or investments may face when operating in more

\begin{tabular}{|c|c|c|c|c|c|c|}
\hline & & Inflows: & & & Outflows & \\
\hline & 1993 & 1994 & $1995^{\circ}$ & 1993 & 1994 & $1995^{\circ}$ \\
\hline Australia & 3,381 & 3,789 & .. & 1,087 & 5,908 & .. \\
\hline Austria & 982 & 1,314 & 530 & 1,467 & 1,201 & 1,050 \\
\hline Belgium-Luxembourg & 10,458 & 8,899 & .. & 3,843 & 2,492 & .. \\
\hline Canada! & 4,980 & 6,031 & 11,182 & 5,805 & 4,778 & 4,782 \\
\hline Czech Republic & 568 & 862 & 2,558 & 90 & 116 & .. \\
\hline Denmark & 1,684 & 4,890 & 4,179 & 1,379 & 4,040 & 3,018 \\
\hline Finland & 865 & 1,578 & 917 & 1,407 & 4,298 & 1,517 \\
\hline France ${ }^{1}$ & 12,142 & 10,955 & 12,156 & 12,167 & 10,895 & 9,582 \\
\hline Germany & 240 & $-3,003$ & 9,012 & 19,557 & 14,587 & 34,890 \\
\hline Greece & 977 & 981 & .. & .. & .. & . \\
\hline Hungary & 2,339 & 1,320 & 4,570 & 11 & 49 & 1,480 \\
\hline Iceland' & -5 & .. & .. & 16 & .. & . \\
\hline Ireland & 88 & 90 & .. & .. & .. & .. \\
\hline Italy & 3,751 & 2,236 & 4,347 & 7,231 & 5,108 & 3,210 \\
\hline Japan' & 86 & 888 & 37 & 13,714 & 17,938 & 22,262 \\
\hline Mexico & 4,901 & 7,978 & 4,500 & .. & . & \\
\hline Netherlands & 6,507 & 4,371 & 5,889 & 10,993 & 11,502 & 7,929 \\
\hline New Zealand & 2,376 & 2,790 & 2,796 & $-1,455$ & 2,259 & 1,483 \\
\hline Norway & 1,951 & 651 & 1,363 & 882 & 1,862 & 2,446 \\
\hline Portugal & 1,378 & 1,254 & 533 & 107 & 283 & 606 \\
\hline Sweden & 3,690 & 6,328 & 13,672 & 1,394 & 6,612 & 10,367 \\
\hline Switzerland & -83 & 3,229 & .. & 8,765 & 11,026 & \\
\hline Turkey & 1,016 & 830 & 935 & 175 & 78 & 165 \\
\hline United Kingdom & 14,536 & 11,066 & 29,910 & 25,697 & 29,721 & 37,839 \\
\hline United States & 41,108 & 49,448 & 74,701 & 72,601 & 49,370 & 96,897 \\
\hline Total OECD & 126,662 & 138,799 & 190,723 & 189,532 & 188,022 & 243,055 \\
\hline \multicolumn{4}{|c|}{$\begin{array}{l}\text { a. Provisional figures. } \\
\text { 1. Reinvested earnings are excluded from national statistics. }\end{array}$} & & & \\
\hline \multicolumn{4}{|l|}{ Source: OECD } & & & \\
\hline
\end{tabular}

than one state. A number of important issues arising from the institutional framework for implementing the MAI must also be addressed, including the relationship with the WTO agreements and with existing $\mathrm{OECD}$ instruments. And consultations with non-OECD countries will be intensified, in particular with those interested in acceding to the MAI.

It is clear, therefore. that in the coming months the negotiators will have to make some difficult choices. Some issues might only be resolved in the final phase of the negotia- tions. The OECD countries have expressed their determination to maintain the present momentum of the negotiations so as to achieve an agreement by the Ministerial meeting in early summer 1997. A successful outcome would mark an important mile-stone in international co-operation.

\section{OECD BIBLIOGRAPHY}

Towards Multilateral Investment Rules, 1996 Introduction to the OECD Codes of Liberalisation of Capital Movements and Current Invisible Operations, 1995

Code of Liberalisation of Capital Movements, 1995 International Direct Investment Statistics Yearbook, 1995

Financial Market Trends, Nos. 57-62, 1994-95 International Direct Investment Statistics Yearbook 1994

National Treatment for Foreign-Controlled Enterprises, 1993

International Direct Investment Statistics Yearbook, 1993

OECD Declaration and Decisions on International Investment and Multinational Enterprises, 1992. 


\section{Labour \\ Standards \\ and}

Raymond Torres

The issue of trade and labour standards is a topic of international debate. It has partly to do with trade-related concerns: does the failure of some countries to comply with given labour standards allow wages and production costs to be reduced and, by the same token, international competitiveness to be improved? If that were true, talk of unfair practices would be justifiable and compensatory trade sanctions could be envisaged. But labour standards embody another element buman rights. Some commentators argue that, in a globalised economy, the international community cannot tolerate the flouting of standards which are seen as workers' basic rights, nor can the countries responsible be allowed to share equally in the trade concessions resulting from the process of trade liberalisation - quite apart from any possible effects on the competitiveness of firms.

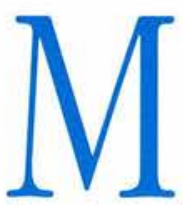

uch controversy surrounds the issue of trade and labour standards. Some countries would like to introduce a social clause. applicable by the World Trade Organisation (WTO), with a view to sanctioning countries which do not observe specific labour standards. Others simply want to see the WTO initiate discussions on this topic. Others yet do not want the WTO to tackle the issue at all, for two reasons. First, they refute the existence of any causal link between labour standards and trade, thus excluding any possibility of unfair competition. They see the argument as an excuse to weaken the competitiveness of low-wage countries and hold that these good intentions mask protectionist ambitions. More generally, they refuse to burden trade policy with the task

Raymond Torres works in the Employment Analysis and Perspectives Division of the OECD Directorate for Education, Employment, Labour and Social Affairs. of rectifying social problems, which is the concern of the International Labour Organisation (ILO) or other such bodies,

The debate about the links between labour standards and trade has been confused because of the lack of any precise definition of those standards. In some cases, people refer to labour standards in the broad sense of the range of laws and regulations that govern working conditions. Others cite a more restricted list, the content of which varies from one observer to another. An OECD study ${ }^{1}$ has identified a small number of standards - called 'core labour standards' - which it is thought could help clarify the debate:

- the elimination of exploitative child labour

- the abolition of forced labour

- non-discrimination in employment

- freedom of association and collective bargaining.

These standards were chosen because they form an integral part of human rights. They are contained in a number of United Nations texts, such as the Universal Declaration of Human Rights, and their importance was reiterated in the Declaration from the 1995 Copenhagen World Social Summit. Thus defined, they should apply, like other human rights (the right to life, freedom of expression, and so on), in all countries, whatever their degree of economic development. There is strong support for core labour standards not only in the majority of the wealthy OECD countries, but also in many developing countries. Other labour standards, by contrast, such as the minimum wage or social protection, are not looked upon as human rights and are endogenous' in the sense that they depend on the stage of economic development obtained. It is therefore undesirable that other labour standards should be harmonised. For example a sharp increase in the minimum wage imposed on the developing countries would damage their economic prospects, employment and working conditions.

Another characteristic of the core standards is that they are a necessary condition for the supply of and demand for labour to be able to be expressed freely - for example, freedom of wage-bargaining is meaningless where there is forced labour.

\section{Is there a Link between Standards and Trade?}

Any analysis of this controversial question has to be based on precise information on the nature of breaches of core labour standards. But this sort of information used to be both diffuse and incomplete. For example, there was no comprehensive study examining freedom of association across the world, nor an inventory of cases of exploitative child labour. The OECD has now collected together the existing information and analysed the status of freedom of association and the right of collective bargaining in more than seventy countries. These include all the OECD countries and those non-member countries most active in international trade. It emerges that legis-

1. Trade, Employment and Labour Standards: A
Study of Core Workers' Rigbts and International Study of Core Workers' Rigbts and I
Trade. OECD Publications. Paris, 1996. 


\section{Trade}

lation and practice in most OECD countries are consistent with the principle of freedom of association and the right of collective bargaining. Restrictions on that principle, by contrast, were observed in the majority of the nonmember countries considered in the study. Those restrictions can in some cases be relatively minor, as in Argentina, Chile and India for example, but they can sometimes be so extensive that freedom of association is practically non-existent, as in China, Indonesia and Iran.

The OECD study considers the possible impact of these differences on international trade and foreign investment, concluding that it is impossible to prove the existence of an empirical link between these standards and global trade performance (or foreign investment); the argument that non-observance of core labour standards gives rise to unfair trading practices cannot be proven empirically. And theory suggests that, in general, trade enhances general prosperity, whether or not all the trading partners abide by the core standards. The classical trade models show that patterns of specialisation probably depend not on standards which are observed to varying degrees, but on relative factor-endowments, technology and economies of scale.

Empirical work, once again, suggests that there is no global correlation between growth of real wages and the degree of respect for freedom of association. During the 1980s, for example, real wages rose faster in those countries which had the least rather than the most respect for core standards. Conversely, there is nothing to show that countries with weak standards have export results that are generally better than those with high standards.

Contrary to what is thought by those who subscribe to the theory of unfair competition, failure to observe core labour standards can hamper the economic efficiency of a country and the growth of its exports. This is because the exploitation of child labour, discrimination in employment, slavery and exploitation of labour in general are liable to perpetuate arrangements that are economically inefficient. The exploitation of child labour, for example, hinders the development of human capital and thus re-

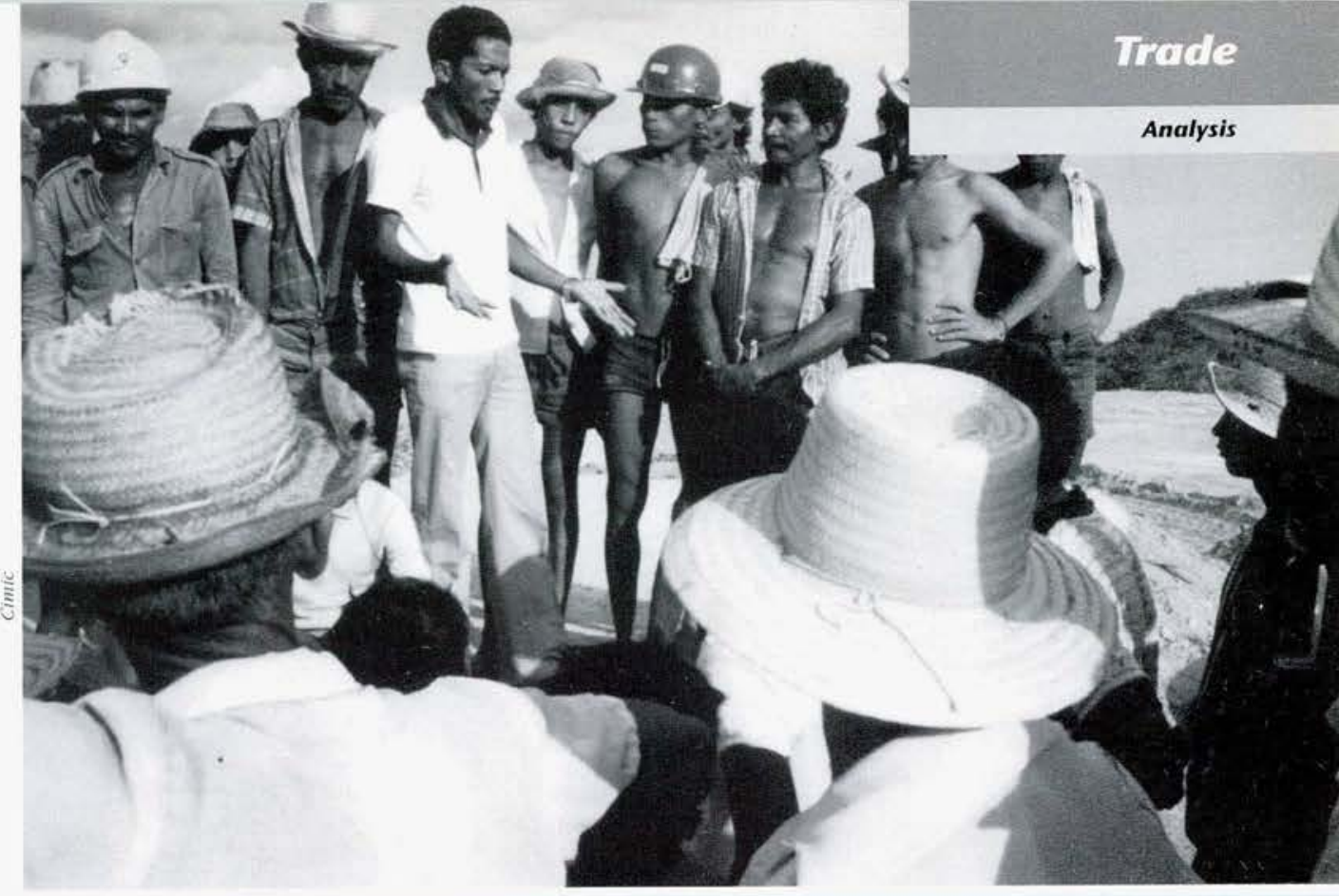

The principle of freedom of association is a core labour standard.

tards improvements in productivity; discrimination in employment results in situations in which some workers are not employed in the positions where they would be most productive; the lack of freedom of association undoubtedly makes it more difficult to introduce modern methods of human-resource management and generates an unstable social climate which does not encourage productive investment. It follows, therefore, that countries with low standards can strengthen them without fear of an unwanted impact on their economic development.

\section{Promoting Standards}

The most appropriate mechanisms for promoting core labour standards are those which tackle the causes of low standards. In this connection, it is useful to note that there are three main reasons that core standards are not observed.

First, there are a number of non-democratic countries, such as China, Iran, Myanmar and Syria, whose governments do not feel concerned by core labour standards. This is mainly a political problem, and in such cases the international community can exert pressure by means of the existing United Nations mechanisms and, if necessary, embargoes or other economic sanctions.

Second, there are other, mainly less-developed countries (India, for example) which have democratic political systems and adequate legislation, but which do not always have the means to enforce it on unscrupulous emplovers.
Third, there is in some countries a deliberate policy to apply lower standards in certain export sectors or in export-processing zones in order to attract foreign investment, the main countries concerned being Bangladesh, Jamaica, Malaysia, Pakistan, Panama, Sri Lanka and Turkey. But it is difficult to say for certain that this policy has produced any results, and it can even be claimed, as suggested, that in the long term the effect is the opposite of that sought.

In most cases, ILO procedures can play a useful role. The ILO has a whole range of Conventions covering core labour standards: Conventions 87 and 98 on freedom of association and the right of collective bargaining. Conventions 29 and 105 on the prohibition of forced labour and Convention 111 on non-discrimination in employment. These Conventions have been ratified by the majority of $O E C D$ countries and by a large number of countries that are not members of the OECD. It would also seem that most of the countries which have not ratified these Conventions endorse their underlving philosophv, their failure to do so being attributable to the fact that they consider them either too detailed or out-of-date. The possibility of the Conventions being revised cannot therefore be ruled out, since it would enable more countries to ratify them. Where child labour is concerned. the ILO has a number of Conventions on minimum age and its studies are helping to make the issue better understood. But, for the time being, the ILO does not have a convention relating specifically to the exploitation of child labour. The ILO can exert pressure on countries which do not apply the conventions that they have ratified. It also has a special committee 


\section{Labour Standards and Trade}

which examines breaches of rights of freedom of association and this procedure, which applies to all ILO member countries, appears relatively effective.

In order to improve the implementation of core standards in the developing countries, financial assistance could be made subject to compliance with them and aid to education could be promoted, which would help reduce the prevalence of child labour.

A number of steps have been taken in recent years to ensure that consumers are better informed about where products come from, so that those made by children or under exploitative conditions may be penalised. This sort of method of promoting standards may be effective for relatively homogeneous products the source of which can be easily identified, but vigilance is required: guile and untruthfulness are a real danger.

The preparation of a code of investment ethics is a way of making multinational enterprises, and more especially foreign investors, aware of their responsibilities in social policy, and of encouraging them to comply more closely with core labour standards in the countries in which they invest. The OECD Guidelines for Multinational
Enterprises are an important example here.

There is already a social clause in the Generalised System of Preferences (GSP) of both the European Union and the United States. These systems offer incentives in the sense that countries implementing core standards enjoy more favourable trade treatment. Analysis of the United States GSP suggests that the system has played a part in improving core labour standards in some countries.

What of the argument that core standards should be introduced into the WTO? From a purely economic point of view, it is a move that would be justified only if it could be shown that 'low' standards do reduce production costs and, second, if standards were 'lower' in export sectors than in others - implying that 'social dumping' was intended. But the OECD study does not point to any empirical link between standards and production costs. It is generally agreed, moreover, that core standards are more closely adhered to in sectors exposed to international

Imports could carry a standard to indicate their respect of core labour standards - but it would require policing.

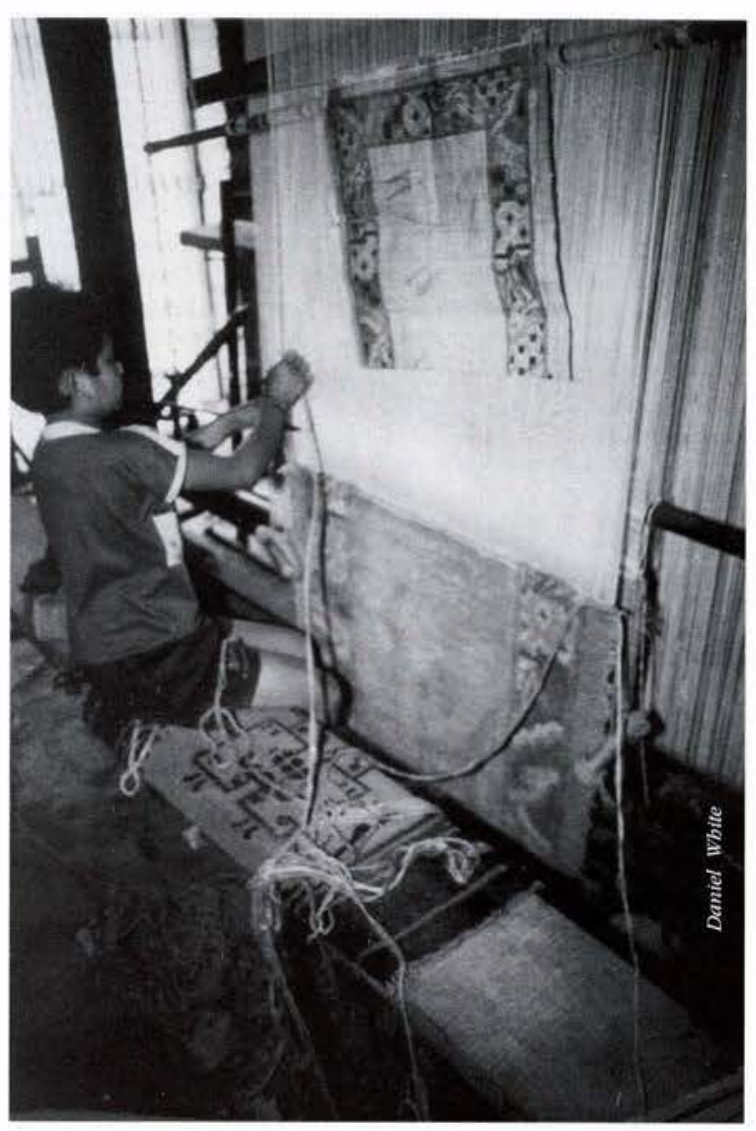

The exploitation of child labour is also economically inefficient. competition than in sheltered ones. In any event, this is a complex debate and one which will certainly continue.

\section{=}

Above all, core labour standards are human rights, and any breaches thereof have to be judged by that yardstick. This being the case, it is surprising that so few studies have been devoted to the implementation and impact of core standards. As a rule, such debate as there is centres on the question of trade sanctions and the potential role of the WTO in promoting standards. In reality, this debate shows that economic analysis is increasingly being called upon to provide answers to questions which, although outside its traditional sphere, are nevertheless of crucial importance.

\section{OECD BIBLIOGRAPHY}

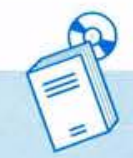

Trade, Employment and Labour Standards. A Study of Core Workers' Rights and International Trade, 1996 OECD Employment Outlook, 1996 OECD Employment Outlook, 1994 The OECD Jobs Study. Evidence and Explanations, 1994. 


\section{Safe Products \\ and Clobal Trade}

Christopher Wagner

The expansion of international markets in consumer goods has been accompanied by two concerns. How can consumers be sure that the products they purchase meet exacting safety standards? And how can the regulators who monitor the market ensure that standards do not function as barriers to trade? The evidence is that duplicative testing requirements often provide no further guarantee of safety; instead, they merely increase costs and delay the introduction of products to the market. So there seems to be some scope for increased use of internationally accepted performance-based standards, mutual recognition of the procedures other countries use to ensure conformity with their standards, and more transparency in safety requirements to ensure that standards are not used for anti-competitive purposes. ${ }^{1}$

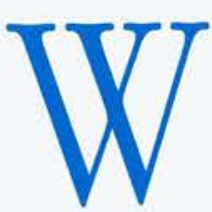

ith the advent of the global marketplace and the regionalisation of economies into trading blocks, issues arising from the standardisation of products and their conformity with a range of testing, certification and accreditation procedures have grown in importance. In the past such questions were addressed by policy-makers from two divergent points of view. First, consumer organisations and market regulators concentrated on product safety and consumer protection. Second. standardisation was considered by international trade authorities in the general context of its effect

Christopher Wagner works in the Competition and Consumer Policy Division of the OECD Directorate for Financial. Fiscal and Enterprise Affairs. on trade: it can form a potential barrier to admission of 'non-conforming' goods into a country.

These issues have been further complicated by the proliferation of marks as distributors. industry, insurance and regulators demand 'seals of approval' for tested products (box, p. 16). Marks have in many cases become commercial products themselves, and standardisation and conformity assessment is now a substantial international business.

International standards, including those promulgated by the International Organisation for Standardisation (ISO), are still not uniformly accepted across major markets. Worries that differing standards may not satisfy national or regional safety requirements have meant that their functional equivalence is seldom mutually accepted by national authorities and product dis- tributors. As a result, industries have to manufacture products to a multitude of different standards and technical specifications. The way requirements are drafted can exacerbate this problem. Those that are too prescriptive can stifle technical development and innovation and hamper trade to the ultimate disadvantage of the consumer.

But the resulting repetition of product-testing often provides no stronger guarantee of safety, and voluntary certification schemes, which in practice can sometimes be required by the demands of the marketplace, may also present problems. This can occur, for example, if the organisations granting certification refuse to accept the results of testing organisations abroad, or prevent the use of quality marks to which such bodies hold the intellectual property rights.

\section{Identifying Common Concerns}

When these safety issues are regarded in the wider context of trade, it is easy to see why consumers and exporters' interests converge. Confidence in the safety of products available on the market is an essential element in the 'package' that consumers buy. But it is also directly in the consumer's interest to ensure the degree of confidence does not come at so high a price that it sacrifices the benefits of open markets: wider choice and competitive pressure on prices. Indeed, exporters of consumer products seeking access to foreign markets obviously have a strong interest in promoting confidence in the safety of their products.

Addressing consumers concerns about safety means taking into account the extent and dynamics of the global marketplace. Its most striking characteristic is the sheer quantity and

1. Consumer Product Safety Standards and Con-
formity Assessment: Issues in the Global Marketplace OECD Publications, Paris, forthooming 1990. 


\section{Safe Products and Clobal Trade}

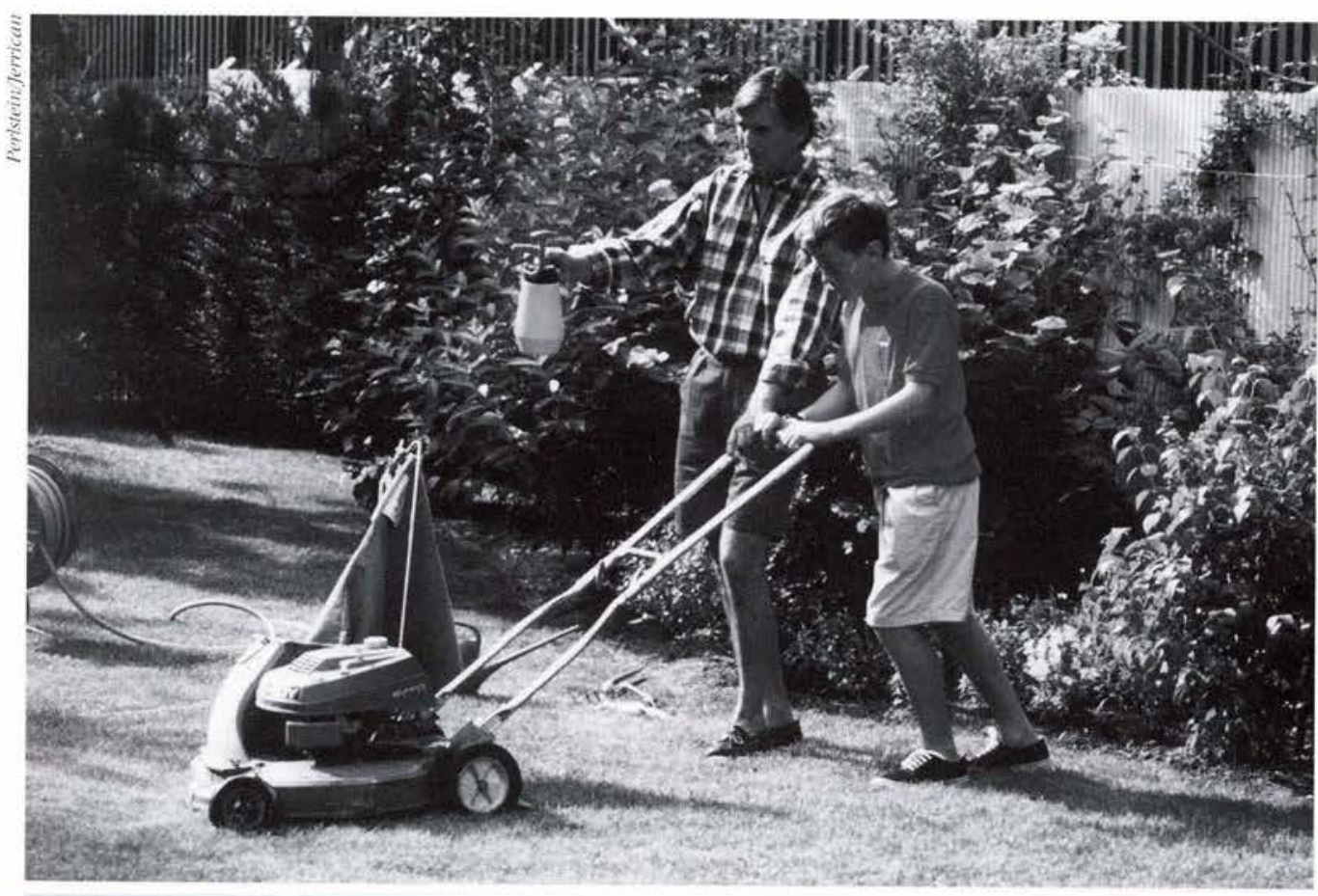

For some products safety is obviously of paramount importance. of what is required of them. Any standardisation measures proposed should neither preclude alternative or innovative ways of achieving equal or better quality nor impose unnecessary additional costs which will ultimately be borne by consumers. Both consumers and manufacturers then benefit: consumers can look forward to wider choice, reduced costs and an atmosphere which encourages technical innovation and diversity while guaranteeing the safety they expect; and manufacturers can market products across the globe without unnecessary repetition of testing and certification procedures.

To reach this end, three main issues must be addressed. The first is the general use of safety-standards. Market forces, including distributors and trade associations, are driving the acceptance of international standards together with regulators and regional trade groups such as the EU, APEC and NAFTA. But further expansion is necessary, and where possible national variety of products available, and the pace at which new ones enter the market. In many instances manufacturing processes have been thoroughly internationalised, and modern retail and marketing practices and internal distribution often involve shipping merchandise across borders to meet demand. Changes in technology and commercial practices, including new methods of quality-control and the management of product safety, call into question many of the assumptions that underlie the traditional responses to this issue.

One of the primary objectives of standardisation - whether mandatory requirements imposed by government or market-driven voluntary ones - is to ensure that consumers in a given market receive the degree of quality and safety that they expect, and that at the same time manufacturers are able to sell into that market with a clear understanding

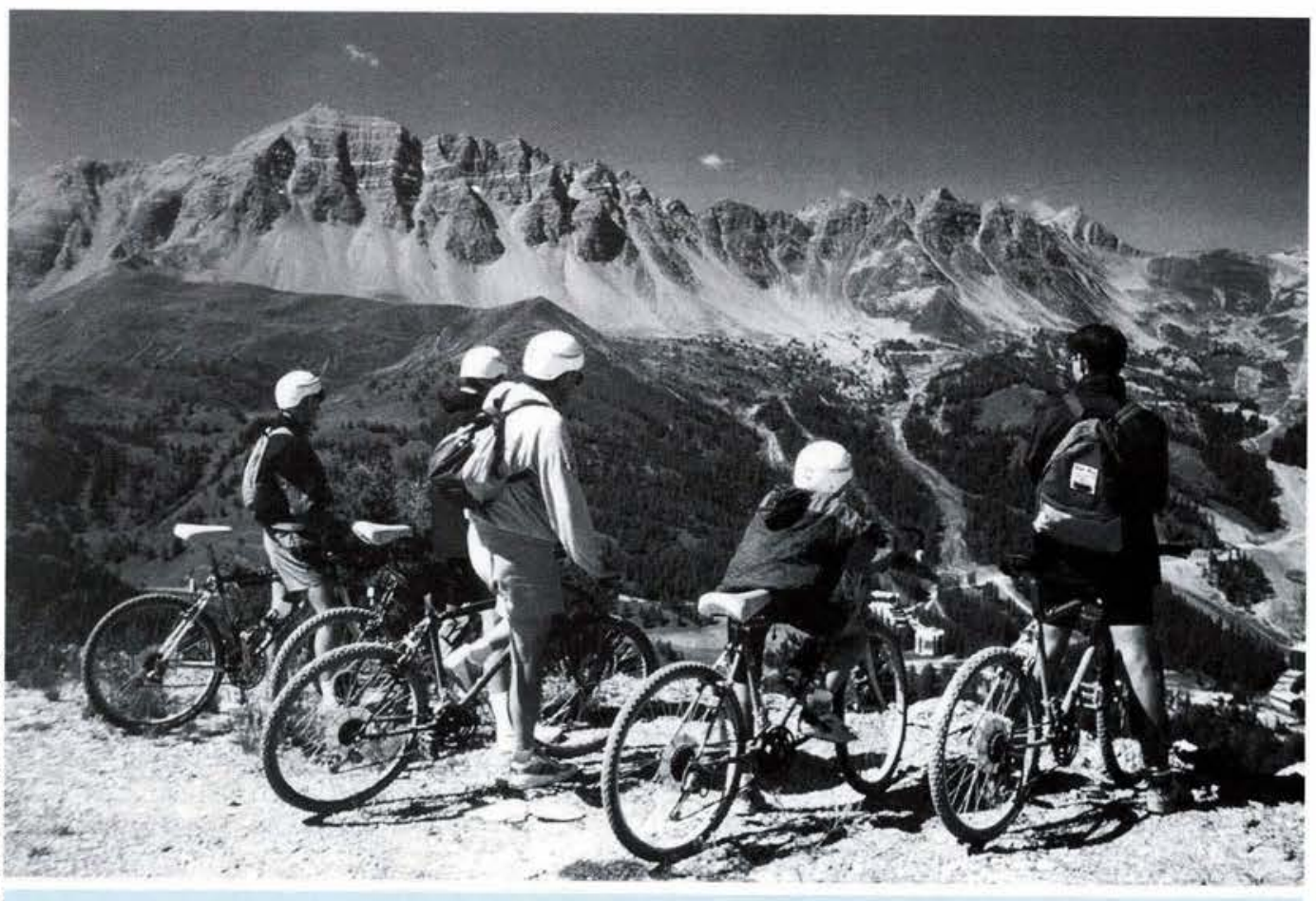

Bicycle helmets: another product where the balance between price and safety has to be right. 


\section{BACKGROUND}

\section{The OECD Survey on Standardisation and Conformity Assessment}

In 1995 the OECD Committee on Consumer Policy conducted an extensive survey of standards and conformity assessment for four categories of consumer products: toys, bome appliances ttaking microwave ovens as an example), outdoor powered equipment (lawnmowers) and personal protective equipment (bicycle belmets). Questionnaires were completed by 95 manufacturers of these products in 14 countries. Other questionnaires were completed by trade associations, safety officials, and bodies issuing standards and assessing conformity with certification procedures Safety standardisation procedures and the requirements of conformity assessment are often product-specific, which makes generalisations difficult. The following conclusions can nonetbeless be drawn from the survey data:

- safety-standards and conformity assessment procedures are beld to be among some of the most pressing trade issues today and are growing in importance

- manufacturers and trade associations bave a strong interest in baving these issues addressed and believe it is necessary to eliminate differences in product safety-standards and promote mutual recognition of testing and certification results, preferably by moving to a single international safety-standard, one international testing and certification procedure, and one intemational safety-mark

- consumers bave a strong interest in participating in the global marketplace and knowing with confidence that the products sold there are safe, although not at the cost of rising prices and diminishing choice

- safety agencies are beginning to consider the effects of standards and other requirements on trade, with some seeing the advantages of market-driven controls and surveillance

- small-and medium-sized manufacturers may be at a competitive disadiantage in satisfying standard and conformity-assessment criteria

- there is widespread confusion in the definition and characterisation of certain basic terminology and concepts, including the meaning of specific marks for consumers and industry.

\section{FOCUS}

\section{The Teddy Bear's Tale}

The toy industry, like most others, is facing a uorld demand for safe, uell-made products at competitive prices. How do standardisation and conformity assessment requirements affect producers of a relatively straightforward and traditional product like the teddy bear?'A small white teddy bear made in the People's Republic of China can help ansuer this question.

All of the components of the bear: with the exception of polycore thread, came from countries other than China. The eves were moulded in Japan and were fixed ultrasonically by a machine made in Soutb Korea. The dress was imported from France. The stuffing material, made of polyester fibre, comes from either Germany or the United States, and the pile fabric was produced in Korea. All of the components were assembled in China. The bear uas created in the design rooms of a mid-sized US manufacturer. whose engineers produced the manufacturing and safety specifications for the manufacturer's customers in Brazil. Canada, the European Lnion. Japan. Mexico and the United States.

For shipments to the United States, a number of standards regulations must be observed. Because some of the bears are sold on a direct basis FOB Hong Kong to four different US general merchandise retailers, four different certificates from four different Hong Kong laboratories must be obtained, eacb certifying that the toy complies with US federal regulations as well as ASTM F-963, the voluntary toy safetystandard in the United States.

To take advantage of freight rates, the product is shipped to Canada, Brazil and Mexico at

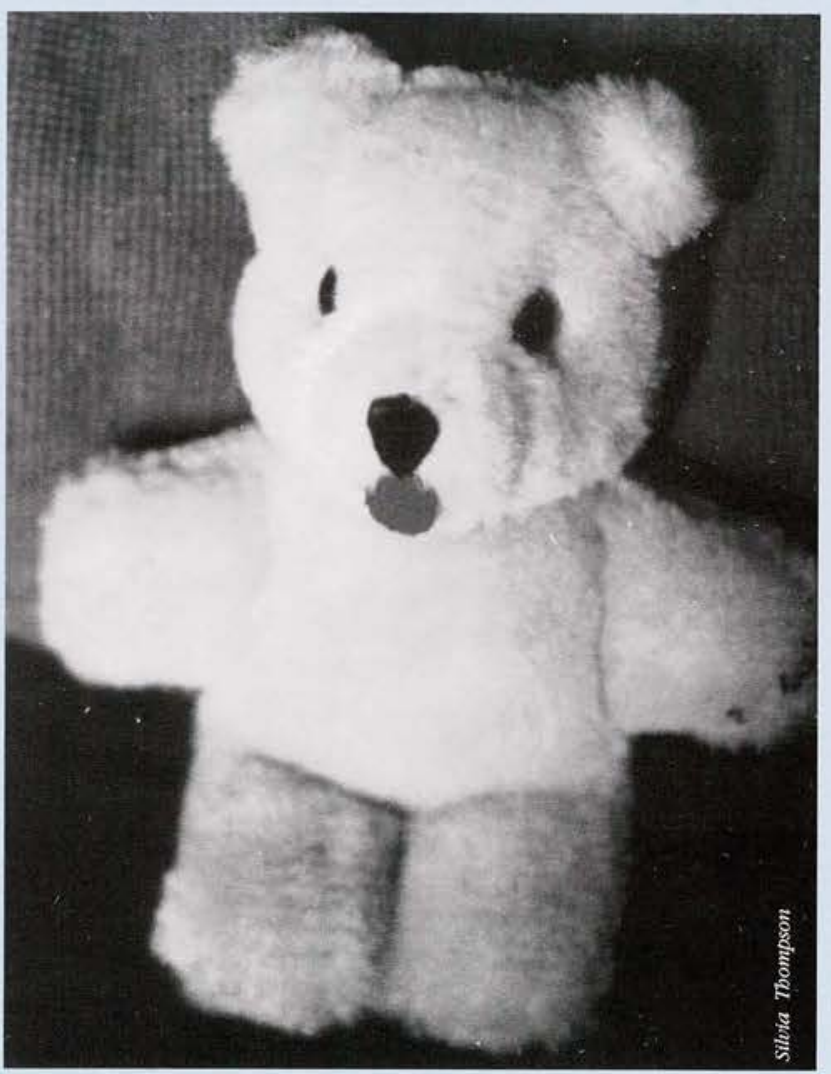

lags and labels to indicate compliance with Japanese regulations on toy safety, and must meet the testing requirements on the formaldebyde content of products destined for infants. For shipments to the European L nion, the tedd. bear must bave hand-tags and labels with the appropriate 'CE' mark on it, indicating compliance with EN71, the European standard for toy safety. The company making this particular toy bas designated its London office as the official site for the 'technical file wbich establishes the fact that the company uses quality-assurance methods and has the systems necessary to assure the same time. The labels and

band-tags on the toy will therefore appear in English, Spanish and French, and products beaded for Brazil will require certification from a recognised US or Brazilian laboratory that the requisite standard - partially American and partially European in origin - bas been complied with. For shipments beaded touard Japan. the Japanese ST mark must be placed on the compliance with European standards, and all EU customs inquiries about this product must be referred back to the United Kingdom. In case of disputes, customs officials may detain the shipment pending translation of the file. This can result in delays and increased costs for a product which has already been extensively tested. 


\section{Safe Products and Clobal Trade}

\section{FOCUS}

\section{What Does a Mark Mean?}

A 'mark' is a symbol on a product wbich describes certain qualities: its properties when tested, approval by testing laboratories, conformance to regulations or to the demands of importers or distributors, technical characteristics (voltage, wattage, thread size), whether it meets or exceeds safety or quality standards, implicit or explicit. The 'CE' mark of the European Commission, for example, found on a broad variety of consumer goods, is not primarily intended to inform consumers about the characteristics of a particular product, as in the case of a quality mark (which are often supplied by independent laboratories which undertake testing about the qualities or performance of a product). Instead, the CE mark is aimed at informing inspectors and customs officers that the product is claimed to bave been produced in conformity with the relevant directives of the European Commission on product safety, a requirement which must be satisfied before the product is placed on the market. But the CE mark is only one among many; the $O E C D$ survey suggests that the proliferation of marks and uncertainty about their real meaning may be confusing mamufacturers and consumers alike.

and regional standards should be harmonised with existing standards promulgated by the ISO and the International Electrotechnical Commission. Mandatory and regulatory requirements may best be satisfied by broadly expressed 'performance requirements', which specify acceptable parameters within which a product must function under normal conditions of use, rather than prescribe particular characteristics of design. This approach will help to ensure that standards do not stifle innovation. Standards with equal effect, identified through their conformance to 'performance requirements', should then be recognised by industry, distributors, and national and regional governments alike, and not be subject to discrimination through refusal to allow goods to enter a given market or to distribute them there.

The second main issue is the mutual recognition of conformity-assessment procedures. The existence of harmonised standards and technical regulations will not on its own necessarily guarantee free movement of goods onto different foreign markets. As with safety-standards, differing requirements for the testing and certification of products, either for mandatory or market-driven reasons, can impede trade and mean that manufacturers incur unnecessary extra

2. Jeanne Richards. Testing Pesticides: The OECD Observer. No. 198, February/Marcb 1996. costs, which are ultimately passed on to the consumer. Assessment to check that goods conform to agreed minima is essential. When third-party assessment is required, for certain hazardous materials that require an 'independent opinion,' mutual recognition of testing and certification can much reduce the pointless repetition of certification procedures. ${ }^{2}$ Agreements between governments, between conformity-assessment bodies and between accreditation bodies are an important step towards meeting consumer and market demands. The use of mandatory thirdparty certification in particular increases costs to the producer. One response may be to allow manufacturers themselves to declare the conformity of their products to existing standards, supported by systems of market surveillance (through consumers' associations, for example), although testing by third parties may still be imposed when necessary (with dangerous or hazardous products) to ensure the required degree of safety.

More transparency, too, is desirable in specifying the requirements products must satisfy before they can be introduced into the market. The processes by which standards are drafted must also be transparent, and require the active participation of industry, consumers, regulators, insurers (who have to determine an acceptable degree of risk) and other interested bodies. This consideration is particularly relevant for voluntary standards and conformity-assessment procedures that have been developed by the market itself. Of course, such procedures should not be used for anti-competitive purposes, and must not discriminate against foreign producers. Manufacturers, distributors, wholesalers and retailers should understand the procedures involved in standardisation and conformity assessment so that all parties can capitalise on measures adopted to ease regulatory burdens.

With harmonised standards and certification procedures, consumers can be confident that products sold throughout the global marketplace meet the same high safety-standards everywhere. Manufacturers can avoid costly and unnecessary testing, and their innovative products will gain access to markets more speedily. Regulators can deploy increasingly scarce resources elsewhere, confident that products have been adequately tested and meet exacting requirements. All parties can move closer to the ideal: a broad selection of safe products at competitive prices, with a single international standard for safety, a single international testing and certification procedure and a single international range of safety-marks. 


\section{Flexible Firms, Skills}

\section{and Employment}

Graham Vickery and Gregory Wurzburg

Recent years have seen a number of developments in the labour market, not least increasing variation in wages and the growing use of non-standard employment contracts (part-time and casual work). How much are these trends linked to competitive pressures that are encouraging enterprises to become more flexible and responsive so as to improve productivity and quality and increase innovativeness? What kinds of changes are enterprises adopting? How widespread are new, flatter organisational structures based on high skill and high trust? What are the impacts on workers? Are changes observed in individual enterprises consistent with developments in the labour market? And what are the implications for government policy?

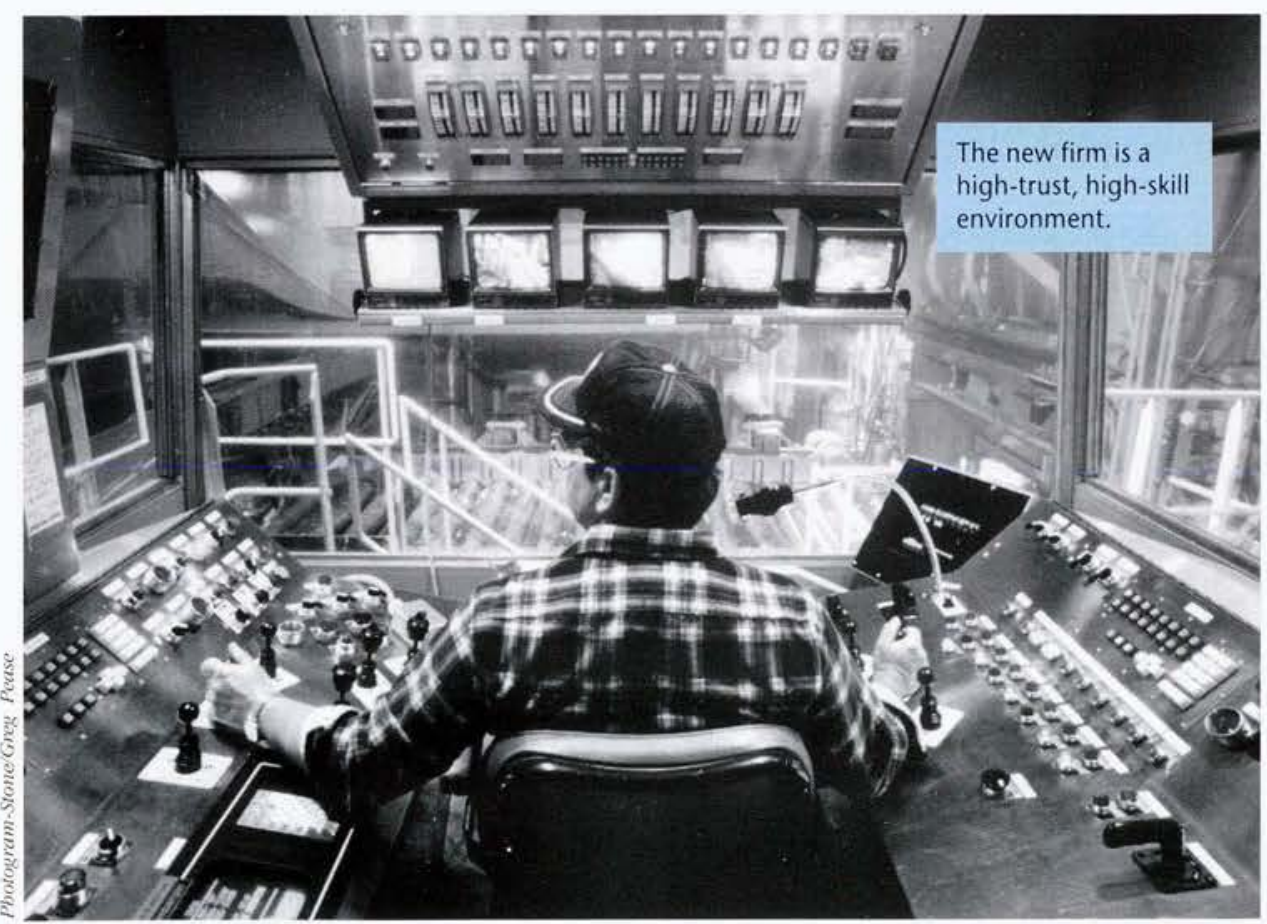

T ndustrial competitiveness is governed by more than the external business environment, the cost of labour, the availability of qualified workers, customer preferences and the cost of capital. Competitiveness depends crucially on how enterprises organise themselves, how they use and develop the human resources available to them, how they match technology and workers, and their relationship to their suppliers and customers and to other firms. In a volatile business climate in which investment, production, and sales opportunities abound - and the pressure to exploit those opportunities is intensifying - the capacity of enterprises to stay competitive depends on their ability to adjust internal capacities quickly.

Organisational strategies, either alone or accompanying the introduction and use of information technologies, are leading to new forms of work organisation (box, p. 18), based on higher and more diversified skills, more horizontal communication among employees and more widely distributed responsibilities within and among business units. It is often identified as a hightrust (because of the distributed responsibilities and more equal horizontal communications), high-skill organisation. It has probably been adopted by about a quarter of larger enterprises, including plants run by companies as varied as Coca-Cola, Renault, Motorola, and some leading banks, particularly in more advanced countries and in all sectors facing heightened competition. Competition drives these changes because firms have to increase their innovative abilities - and the only way to cope with this pressure is to use the skills and imagination of employees creatively

Graham Vickery specialises in questions of technological strategy and technology policy in the Industry Division of the OECD Directorate for Science, Technology and Industry. Gregory Wurzburg deals with issues of education, employment and industry training in the Education and Training Division of the OECD Directorate for Education. Employment, Labour and Social Affairs. 


\section{Flexible Firms, Skills and Employment}

\section{FOCUS}

\section{The New Organisation of Work}

\section{Strategy}

- Specialisation of enterprises or business units, focus on 'core' activities. More borizontal inter-firm links for sub-contracting (purchase of parts, components, or services that are part of final producl), and outsourcing (purchasing supporting business services transport, cleaning and ancillary services, for example)

- Work and structure are re-organised to gain efficiencies.

\section{Organisation}

- Horizontal communication more important, vertical and bierarchical less so

- Information gatbered more widely and channelled less bierarchically.

- Authority to act less dependent on bierarchical models of authority

- Small self-managing or autonomous work groups are common and take more responsibility

- New organisation is essential to use neu technology effectively.

\section{Human Resources}

- Priority on education, training, skills, and experience, as well as on ability to communicate and work in relatively unstructured situations

- Better use of better-trained and more responsive employees

- Multi-skilling and job-rotation increase. blurring differences between activities.

\section{Wages and Conditions}

- Pay for individual skills and competences. productivity-sbaring and profit-sbaring

- Incentives for improvements in efficiency. quality and product-improvement.

at all strata to increase quality, provide new solutions to problems and increase productivity.

In manufacturing, it is assembly industries, and particularly automobile manufacture, that have been the first to adopt these changes, with the accent on quality and flexibility, reducing the capital required and stocks held, and shifting from vertical integration, where firms supply most of their own inputs, to horizontal supply arrangements, where they use external suppliers of goods and services. These are increasingly high-value-added goods and services, including R\&D. design and engineering services to develop new components from suppliers with long-term links with central purchasing companies.

In services, the new organisation appears to be less common, although financial services and other tradable and business services are likely to adopt it, since they are facing deregulation and rapid changes in the conditions of competition because of the rapid diffusion of new technologies and market entry of new competitors. In spite of widespread interest in the new organisation, in some industries and activities there is little scope for adoption of some features of the new organisation such as autonomous selfmanaged team-working. And in the past, industries and consumer services isolated from international competition had little incentive to change because there was little or no international trade and investment. And government services, too, such as health care, were usually locally provided by national agencies, with little competition.

What measurable impacts do these changes bring to the firms that adopt them? Training and education, when combined with changes in organisation, technology, and human-resource management practices (pay for performance or flexible scheduling, for example) are associated with direct gains in productivity, shorter production cycles, and improved product quality. There are likewise close links between industrial organisation (to permit the effective use of technology), skills and training on the one hand, and productivity and competitiveness on the other. The lines of causality are not simple and have to be traced through a combination of organisational structures and work practices. Involving employees directly in the management and organisation of their tasks and in improving the performance of the firm, rewarding skills and increasing workers' efforts in other ways (such as paying for useful suggestions and sharing productivity gains and profits) can be combined with train-

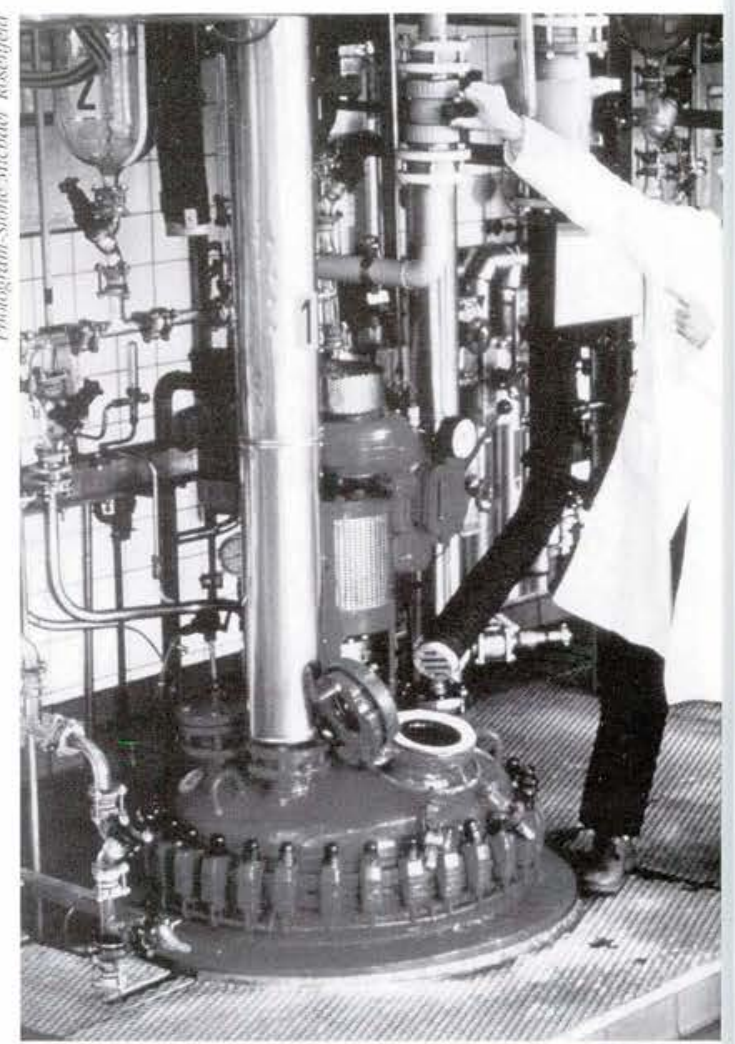

A well-trained workforce can mean improved productivity, shorter production cycles and improved quality - though the lines of causality are far from obvious.

ing and the development of multiple skills that cover a variety of tasks. It is this 'bundle' of strategies - efficient workplace organisation, wider distribution of responsibilities, individualisation of rewards and a highly skilled workforce - that improves performance.

Organisational changes of this sort are likely to be sustainable because they improve productivity and quality, and help generate profits. But the impacts on aggregate employment of organisational and technological change will depend on how improved performance is translated (through its effects on price and income) into aggregate employment, 'as well as on the extent to which these changes are adopted. And although there are major competitive reasons and very large scope for the adoption of the new work practices and organisational structures, a 


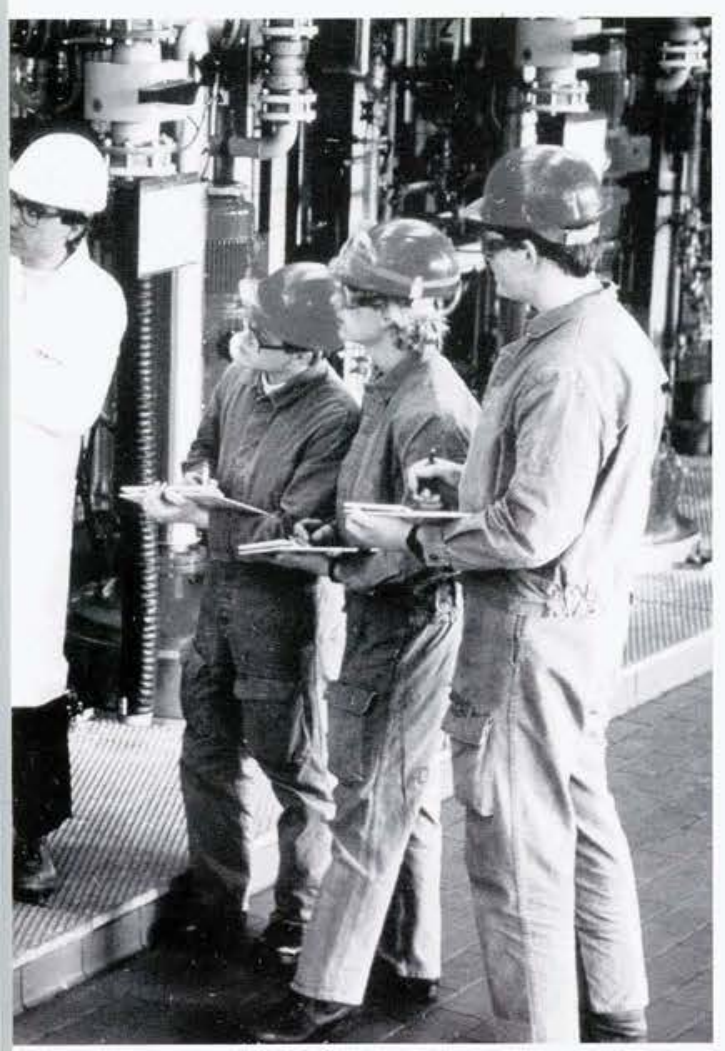

large number of barriers remain. many of them internal - and often derived from management.

\section{Three Kinds of Adaptability}

Across broad groups of countries, three approaches to adaptability and flexibility can be discerned. Each has different strengths and weaknesses, and each involves different trade-offs in the process of further enhancing adaptability and flexibility. One, a market-driven approach', is typically found in firms in North America, Australia. New Zealand and the Lnited Kingdom. Within the relatively liberal structure of factor and or product markets, firms have followed a variety of strategies to achieve adaptability and manage risk while maximising returns to shareholders and satisfying other short-term financial criteria such as quarterly profit performance. Flexibility depends to a fairly high degree on the ability of enterprises to add and shed fixed assets through take-over and divestment strategies. Workforce adaptability is achieved through welldeveloped external labour markets, so that firms can dismiss workers whose qualifications are no longer apposite and hire those with the desired skills.

This approach has more of the elements of numerical and external flexibility. But there are institutional, historical and regulatory differences among countries. Australia, for example. has on the one hand, liberalised product markets, and on the other, relatively high unionisation and until recently a centralised wage-setting system.

A second approach, more 'relations-based' or consensual, is found among German industrial firms, and in varying degrees in the Nordic countries and other countries in continental Europe, such as Belgium. France and the Netherlands. It is based heavily on negotiation to reach consensus among a wide range of stakeholders: including employees, suppliers, customers, and often the wider community, rather than narrowly conceived share-holder ownership. It is derived in part from the more restricted nature of capital markets and the concentration and cross-holdings of capital ownership in banks and corporations.

The approach engendered allows a more deliberate, often longer-term approach to strategy and resource allocation. This tradition of decision-making by consensus, partly along the lines of the 'German model' of participation in decisions, is being extended through works councils encouraged by the European Lnion. Heavy investment in education and training systems has produced a deep base of skills in the labour pool and high degrees of individual competence. making their workers generally more readily adaptable to changing circumstances. The more consensus-based approach to decisions about firm strategy and development of worker skills has been complemented by consultation between firms in the same sector. Together. these ingredients have helped create a virtuous circle of skill formation, labour re-allocation, productivity growth and employment security - but it may

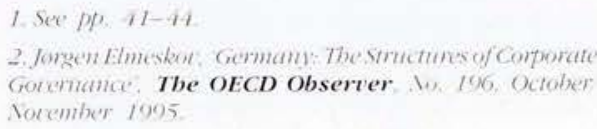

\section{FOCUS}

\section{The Blurring Lines between Functional and Numerical Flexibility}

\section{Functional Flexibility}

Usually involves bigh skills and a collaborative approach to work, and uses bigh-quality labour. Its features are:

- broadening job design and job boundaries

- mobility across tasks

- extending the range and depth of individual skills

- extensive training and retraining. Autonomous, self-managed. multi-functional team-work is an indicator of this kind of flexibility.

\section{Numerical Flexibility}

Usually involves changing the quantity of labour imput. Quantitative changes include:

- numbers of employees

- bours of work

- use of part-time employees

- use of temporary employees whose contracts can be terminated, using liberal provisions on biring and dismissals.

A spatial dimension has also emerged as enterprises rely more on oulsourcing, strategic alliances, and interactive relations with suppliers and customers.

\section{Internal Flexibility}

Within the enterprise or the existing contractstructure of the enterprise.

\section{External Flexibility}

Involves interaction in markets outside the firm. It usually involves changing the nature and type of contracts.

There bas been mucb overlap between internal and functional flexibility, and external and numerical flexibility. Enterprises pursuing more adaptable organisation and production alter the mix of functional and numerical flexibility to adjust their use of labour. They can also shift the area of adjustment, moving it outside if they have relied on internal mechanisms, and vice versa. 


\section{Flexible Firms, Skills and Employment}

be costly if productivity and quality in production do not develop rapidly enough. This approach has more of the elements of functional flexibility and internal development.

A third approach, also consensual in style, but centred on the firm itself, is found in Japan. As in most European countries, restricted capital markets and the concentrated ownership of capital among large business conglomerates have kept strategic decisions focused on developing technology and achieving a given share of the market rather than on short-term financial performance. The adaptability of labour has been achieved through an education policy that provides a broad base of general abilities, and highly developed practices for making full use of a company's human resources. The lesser emphasis, in comparison with most European countries, on development of occupational skills is offset by firm-based vocational training and intra-firm mobility between occupations and jobs. Here, too, the result has been a virtuous circle of skill formation, labour re-allocation. productivity growth and employment security, particularly in large firms. This approach also has more of the elements of functional flexibility and internal development.

But global competition has meant that these different approaches are showing signs of changing. In particular, firms seem to be using a wider variety of adjustment strategies than in the past. Firms in English-speaking countries that relied heavily on external flexibility are paying more attention to developing internal human resources and organisational capacities, Part of the strategic focus on core competencies of firms is based on better development and use of internal human and technological resources. Those that achieved flexibility through internal. consensus-based processes of governance and development of firm-specific skills increasingly turn outwards. In France, for example, changes that formerly took the form of internal adjustments are now calling on external markets as the proportion of part-time workers reaches that found in the United Kingdom and the United States, the percentage of temporary workers increases, and tenure drops. In Japan, there are signs that established strategies that used to rely on firm-specific, multi-skill formation are being replaced with recall to external sources to recruit technical expertise.

Many enterprises are also altering their structure and business strategies in the face of increased market liberalisation, technological change and the social transformations that are sweeping the globe. These developments simultaneously give enterprises more opportunities to enter new markets and develop new products and intensify the competitive pressures on them to adapt. Internal changes in structure and strategy provide the means for adaptation, allowing them to stay in business, and, ultimately, provide sustainable employment. The enterprises that do not change risk loss of market-share and failure - and, for the economy, loss of jobs.

But adaptation is not costless. As enterprises pursue new structures and strategies, they externalise costs that they absorbed in the past, such as those for retraining of workers whose jobs have been eliminated, the costs of more flexible working hours where they involve part-time and casual work with few or no fringe benefits, or of pensions, Slow growth of employment and high unemployment have magnified these costs.

\section{Workplace Flexibility}

Demands for human resources have moved in line with the broad thrust of organisational and technological change. There has been a shift from unskilled to skilled and from blue- to white-collar occupations. Minimum qualifications have become more demanding, and there are trends towards achieving different mixes of skills through enterprise training. Jobs tend to be more complex, with individuals responsible for a larger number of tasks, and erstwhile managerial responsibilities are shifted to operators. But the share of employment (including management) not devoted to production has risen, to co-ordinate autonomous work-teams within enterprises or relations with external suppliers.

Much of this is attributable to the emphasis on increasing the amount of available knowledge - about everything from customer preferences, through problems with product quality, to new scientific breakthroughs - and getting it to where it can be used to increase customer statisfaction, improve quality of goods and services and introduce innovations. This has increased the importance of communication skills for workers of all abilities, and in all occupations. Developments in industries as diverse as automobiles and banking show these trends, with more emphasis on quality, responsiveness to customer demands, individualisation of products, use of new technologies to connect customers

3. Candice Sterens, The Knowledge-based Economy' The OECD Observer: No. 200, June/fuly 1996

4. Abrar Hasan and Albert Tuifman, Linking Edication and Work: The OECD Observer: No. 199. AprilMay 1996 
to the supply of goods and services and use of new materials and concepts. ${ }^{3}$

Broadly speaking, firms can adopt two different forms of labour flexibility, involving either high-skill functional flexibility or volume-based numerical flexibility (box, p. 19). To optimise the volume and timing of working hours, enterprises rely more on numerical flexibility, based on parttime and variable work schedules. They also offset the loss of functional flexibility that may accompany downsizing and restructuring to focus on core activities, with increased use of temporary employment, stepping up their reliance on agencies to find interim staff and specialised business services to satisfy new or increased demand.

There are also observable trends towards performance-related pay, rewards for useful suggestions and various forms of profit-sharing. These are particularly designed to improve incentives for employees to contribute to improvements in company performance.

These complex restructuring processes are also reflected in aggregate trends. The shift towards downsizing and smaller, more specialised production units is matched by the growth of producer services such as specialised business services for other firms and individuals (technical, professional or other specialist services), as more inputs are purchased externally. There is a general increase in educational attainment on the supply side. On the demand side, there is a shift towards high-skill, white-collar occupations (managers, professional, technical staff), although in absolute terms in many countries blue-collar high-skill occupations such as skilled craft and trades people have been declining more or expanding less than blue-collar low-skill occupations such as plant operators, drivers and so on. Against a background of increased social demand for education and rising educational attainment. growth has favoured the more highly qualified. Sectors and occupations that are growing most are those in which standards of attainment have risen most, in, for example, rapidly growing business and financial services and high-tech manufacturing. There have also been general shifts towards part-time and temporary employment; these shifts, combined with more diverse forms of compensation, are associated with more variations in earnings.

Governments have to consider which policies and institutional arrangements will best balance the requirements of enterprises, which have to become or remain competitive (and create employment), with the desirability of a more highly skilled workforce, higher productivity, better standards of living and more employment. There are three distinct objectives of particular importance.

First, to ensure that the new structures and strategies are adopted more widely by enterprises, governments may enact policies to improve information flow. In effect, they would extend to organisational, management and workplace practices the kind of policies introduced to facilitate technology diffusion.

A second consideration is how to ensure adequate volumes of investment in human resources. Workers in the core activities of an enterprise as well as those in more peripheral forms of employment (part-time or temporary) have to have access to the training necessary to keep qualifications matched to the requirements of highperformance workplaces. The number of people who leave school without qualifications has to be further reduced. That may require training and education to be more closely linked to the workplace and more sensitive to short-term development in the demand for skills. Closer industry-education partnerships are required to replace the arms-length relation that often exists now between the worlds of work and education. And in order to encourage balance in investment in fixed and human capital, the information on and valuation of human capital in financial markets will also have to be improved.

Third, there is an immediate problem in the loss of social cohesion - through increasing inequality of incomes and the segmentation between full-time employees, those with more peripheral forms of employment, and the unemployed - that appears to be associated with changes in enterprise structure and strategy. Dealing with it may require policies to improve mobility between these groups - for example, by pro-rating all benefits and particularly training and skill development, and increasing the portability and recognition of benefits associated with employment (training, cover against illness, pensions), and rating of benefits according to work effort.

Countries vary in the degree to which policies and the actions of employers and unions moved towards any one of these objectives. A conference that the OECD and Canadian authorities will hold jointly at the end of 1996 aims to identify the role of government policies and institutions in achieving these objectives directly, and to consider the framework conditions that will best harness the actions of employers and unions,

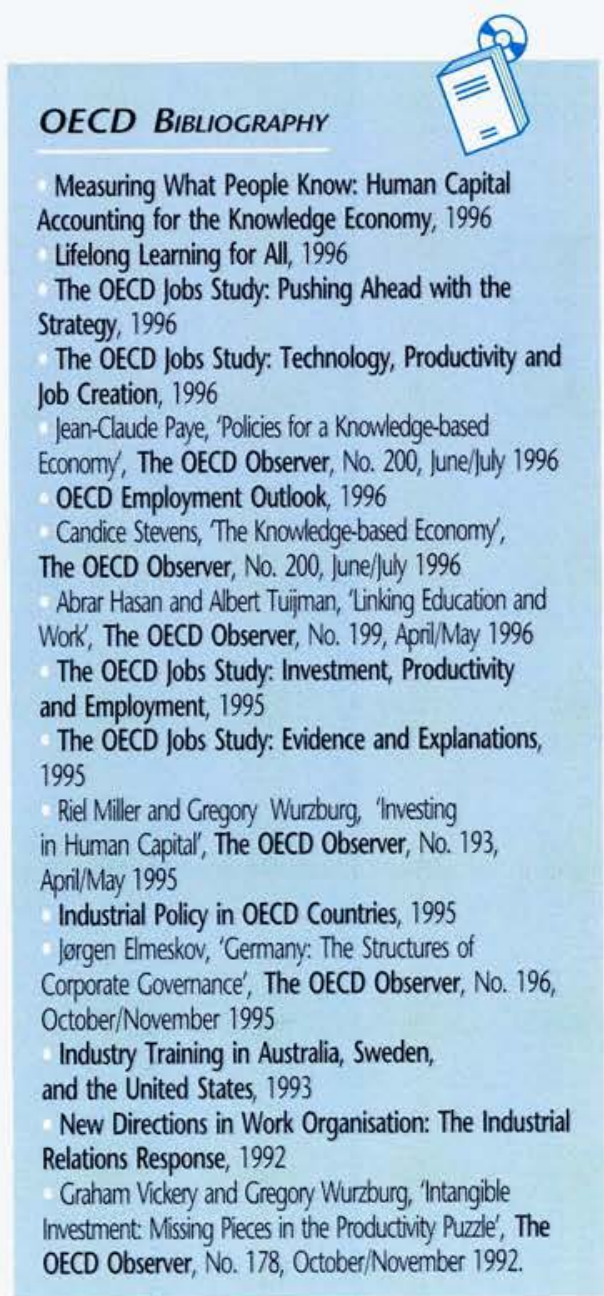




\section{Do Tax-Incentives \\ Promote Innovation?}

Jean Guinet and Hiroko Kamata

Fiscal measures to promote RED and innovation, particularly tax-credits, are now being discussed in many OECD countries, against the background of flagging or negative growth of business RED expenditures. The stakes are bigh: business RED is a vital input to innovation, which is an increasingly important factor in the competitiveness of firms and the main driver of long-term growth in productivity and thus bigher standards of living. ${ }^{1}$

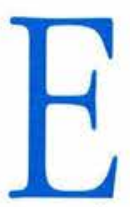

conomic theory, supported by a large amount of evidence from case studies, suggests that firms are unable to capture the full benefits of their investments in R\&D, for two reasons. First, other firms can learn something from the results and appropriate part of the reward. Second, in highly competitive markets for technology-intensive products, the rewards to innovation are very short-lived since they are rapidly transferred to consumers in the form of reduced prices. In the absence of compensating mechanisms, business firms may therefore tend to underinvest in R\&D and innovation.

But there is no magic formula for determining the 'socially desirable' amount of R\&D and, in practice, governments decide on how much they should stimulate R\&D by monitoring and assessing trends in business $R \& D$ and related performances. Economic theory leaves open many options for filling the gap. A first policy option would be to create legal structures that enable firms to keep the returns on their R\&D.

Jean Guinet and Hiroko Kamata work in the OECD Directorate for Science, Technology and Industry.
One means to this end might be to encourage more co-operation between firms in R\&D activities. Another solution, both older and more widely used, is in the use of property rights, such as patents, trademarks, copyrights, but they cannot entirely compensate for the lack of incentive to spend on R\&D since here, too, they are often not strong enough to defend the returns on research.

A second, complementary policy-solution is to increase the private return to R\&D by reducing its cost. Here there are two alternatives: direct government subsidy, and tax-incentives, in the form of favourable tax-treatment of R\&D expenditures. Direct government subsidies are used in all OECD countries and represent the bulk of public financial support to science, basic research, and defence- and health-related R\&D; in many countries it is also the preferred instrument of policies to promote R\&D in particular sectors or

1. Fiscal Measures to Promote R\&D, atcuilable free of change from the Science and Technology Policy Division of the OECD Dinectorate for Sctence. Technology and inchustry.

2. Bronwen Hall, RED Tax Policy During the 1980s: Success or Failure? Tax Policy and the Economy, $1-35(1993)$. technological areas. But when the goal has been to reach a diverse range of firms, both in activity and size, many OECD countries have found that tax-incentives offer unique advantages over subsidies.

First, and above all, they involve less interference in the market and thus allow privatesector decision-makers to retain autonomy in devising their R\&D strategies in response to market signals; this characteristic increases also their political feasibility. Second, tax-incentives require fewer layers of bureaucracy and entail less detailed requirements for receiving assistance than subsidies granted on a project-byproject basis. Third, a policy that involves tax-incentives is for the most part more readily predictable and more stable than one that requires periodic appropriations from government budgets.

\section{Country Approaches}

In all OECD countries the tax-system allows the accelerated depreciation of equipment used for R\&D, often at a preferential rate compared to other types of equipment. And in almost all OECD countries annual current R\&D expenditures can be fully deducted from taxable income, which makes this also a favourable tax-treatment when one considers that such expenditures are an investment that yields revenues over several years.

In addition, many OECD countries have introduced two main types of more specific taxincentives to R\&D (Table, right, and box, p. 24). Extra tax-concessions enable firms to deduct more than $100 \%$ ( $150 \%$ in Australia, for example) of eligible R\&D expenditures against their tax- 


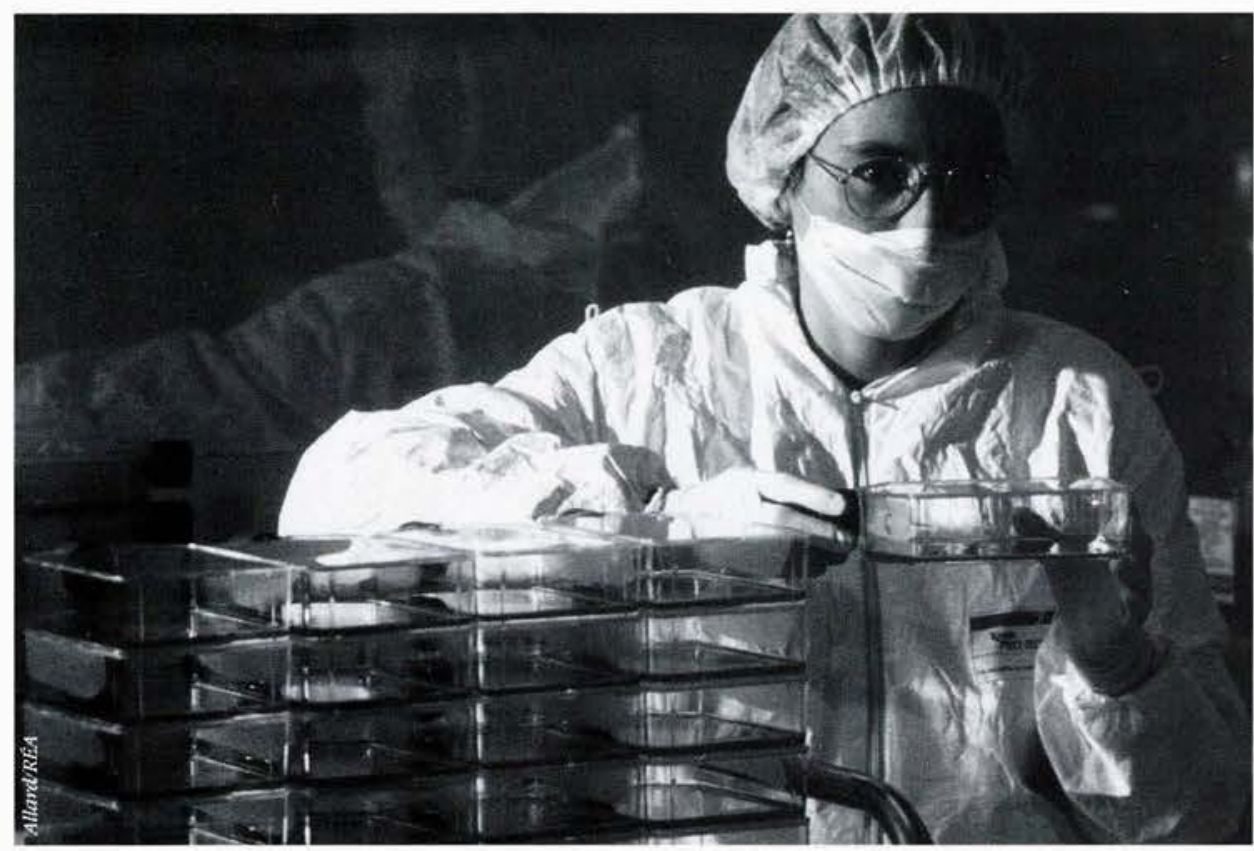

able income. And tax-credits permit firms to deduct a certain percentage of their R\&D expenditures from their tax-liabilities (in Canada, France, Japan, the Netherlands and the United States). Each of these approaches reduces the effective cost of conducting R\&D and thus, at least in theory, increases its supply.

Extra tax-concessions give an incentive proportional to the volume of R\&D performed. That is also true of tax-credits implemented in Canada and the Netherlands. France, Japan and the United States have opted for a different tax-credit mechanism, based on incremental R\&D expenditures, thus providing an incentive proportional to the increase in R\&D outlays in a given year compared to the average real volume of spending during a reference period (in France, for example, the two previous years). Some countries use or have used both approaches - Japan offers volume-based tax-credits to SMEs and some specific R\&D projects, and in France, between 1987 and 1989 , firms were given the choice between a volume-based and an incremental formula.

Tax-incentive mechanisms differ from one country to another in many of their details, including:

- the definition of a minimum volume of eligible R\&D expenditures (for ex- ample, all costs of Research and Experimental Development' in the United States, and R\&Drelated wages in the Netherlands)

- the rate of the tax-credit or-concession

- the ceiling (fixed amount or percentage) imposed on tax benefits

- whether a two-tier system exists, involving both central (federal) and regional (provincial) tax incentives, as in Canada or in Spain

- whether they give differential treatment according to firm-size, region or technology.

Most importantly, they give different solutions to the same problem: how to ensure that firms that have no tax liabilities - firms which are temporarily loss-making because of a cyclical downturn, or newly established companies - are not excluded from the benefits of the tax-incentive scheme. The most widely used solution is to allow tax-credits to be carried forward (Australia, United States) or to be refunded (Canada, France, Spain). Another solution, adopted by the Netherlands, is to apply the tax-rebate not to the tax on profit but to that on wages.

\section{What Effects?}

The percentage reduction in R\&D cost brought about by a given nominal rate of taxcredit or-concession will depend on the rate of corporation tax. Usually it will also vary from firm to firm, for several reasons. One is that many firms may not have sufficient taxable income to offset against the tax-credit, and carry-forward provisions (where they exist) cannot compensate entirely for the resulting loss of incentive. Another source of complication arises with incremental tax-credit mechanisms. For any firm, the real impact of the tax-credit on its total R\&D costs will depend on how the base for calculating the eligible increase in R\&D expenditures is defined and on sector-specific factors influencing the pace of R\&D growth. A study in the United States, for example, by Bronwyn Hall, of the University of California, Berkeley, found that the resulting effect of these factors combined was two-fold: on average, the effective rate of taxcredit was about five times below its nominal rate $(20 \%)$; and the benefits from the incremental tax-credit scheme varied considerably across industries and firms. ${ }^{2}$

A further consideration is how firms respond a taxinduced change in R\&D cost. Some pioneering work on this question was undertaken a decade ago by a team of researchers led by Edwin Mansfield. They spent two years questioning senior R\&D managers about their response to changes in the taxcredit system; surveys were conducted in Canada and Sweden in 1985 and in the United States in 1986. The 


\section{Do Tax-Incentives Promote Innovation?}

\section{FOCUS}

\section{Who Does What?}

The RED tax-incentive schemes of a number of $O E C D$ countries were presented and discussed in a workshop organised last year by the $O E C D$ Working Group on Innovation and Technology Policy. The major characteristics of such national schemes are as follows.

\section{Australia}

A special tax-deduction for RED was introduced in 1985. At present, companies which spend $A \$ 20,000$ or more a year on qualified $R E D$ are allowed to deduct $150 \%$ of that amount from their taxable income. Among the eligibility requirements: RED must involve appreciable novelty or technical risk, results should be exploited in Australia, and there should be a bigh Australian content.

\section{Canada}

Tax-credits of varying sorts bave been used for Research and Experimental Development (REED) since the 1960s. Under the current programme, most companies receive a $20 \%$ credit on total qualified RED. Carry-forward and -backward provisions exist, as does a preferential rate $135 \%$ on the first C $\$ 200,000$ of REED) of refundable credit for small and medium-sized enterprises. Several provinces Quebec, Manitoba, Ontario, Nova Scotia, New Brunswick) bave their own tax-credit schemes.

\section{France}

A tax-credit for RED ('crédit d'impôt recherche') was introduced in 1983. Firms receive a tax-credit equal to 50\% of the increase in qualified RED over average RED expenditure in the previous two years, with an upper limit of FF4O million. Unused credits can be refunded. There are special incentives for new (generally small) companies,

examination found that tax-credits induced only a modest increase in R\&D spending. ${ }^{3}$ But there are several reasons that estimates from subjective evidence may be unreliable, not least that respondants to surveys may not interpret questions in the same way and can have a variable

\section{Japan}

Japan bas the longest experience of tax-credits of all the OECD countries, with a system in place since 1967. Under the current programme, companies receive a lax-credit equal to $20 \%$ of the increase in qualified RED over the highest previous year's RED expenditure, up to a maximum of $10 \%$ of the company's tax-liabilities. There are special incentives for small and medium-sized businesses, for expenditures on special RED activities (including joint research with national laboralories, co-operation with foreign research laboratories, the efficient use of energy and the use of recycled resources) and the acquisition of facilities for basic research.

\section{The Netherlands}

Beginning in 1994, companies can deduct from their tax and social-insurance obligations a fraction of their RED wage-costs. The rebate is $25 \%$ of $R E D$ wage-costs up to 100,000 guilders, and then $12.5 \%$ of RED wage-costs in excess of 100,000 guilders. The rebate cannot exceed 10 million guilders. Self-employed people who spend more than 875 bours per year on RED activities can apply twice a year for an extra deduction of 6.000 guilders

\section{The United States}

A tax-credit for REED was introduced in 1981. Until I July 1995, companies received a tax-credit equal to $20 \%$ of the increase in qualified REED over a defined base amount (average of the 1984-88 period). There are provisions for carrying forward credits not used in the current fiscal year. Start-up companies that do not yet have tax-liabilities are offered a special tax-credit if they spend more than $3 \%$ of their turnover on RED.

and incomplete understanding of the factors driving the evolution of $R \& D$ expenditures in their respective firms.

A different approach is to use econometric techniques to estimate the price elasticity of $R \& D^{\prime}$ - the percentage increase in R\&D induced by a percentage fall in its cost. In the late $1980 \mathrm{~s}$ a first round of studies in the United States ${ }^{4}$ had found relatively low price-elasticity, of the order of 0.4 , indicating little growth in R\&D spending as its cost went down. A new wave of analyses, using improved techniques, have all since found a readier responsiveness of firms to tax-induced change in R\&D cost. Their common estimate of the price elasticity was around unity, suggesting that, for example, a $10 \%$ reduction of the cost of R\&D induces a $10 \%$ growth of R\&D. In addition, Bronwyn Hall has drawn attention to the delay involved in firms reactions to the introduction of a tax-incentive to R\&D; the existence of such a time-lag was confirmed by an assessment of the French incentive scheme.

The important implication for policy-makers is that tax-incentives can indeed elicit significant private-sector responses, especially over the longer term, and that R\&D does not depend purely on technological or demand-driven factors. It rewards not only R\&D spending which would have been undertaken any way but also encourages further efforts. In economic jargon, it thus passes the test of 'additionality'

One could ask whether and to what extent part of the additional R\&D generated by taxincentives was in truth derived from the relabelling by firms of some of their costs as 'R\&D', so to enjoy or increase the benefits of tax incentives. Mansfield's survey of Canada in 1985 pointed to this possible perverse effect and

3. Eduin Mansfield, Public Policy Touards Mndustrial Innotation: in K. Clatk, R. Haves and C. Lorenz reds.). The I neasy Alliance: Managing the Technology-Productivity Dilemma, Harzard Business school Pross Caminidge (Mass, IOS5, Edwin Mansfield. The ReD Tax Credil and Other Technology Policy Issues: American Economic Review, Vol 76 (1986): Eduin Mansfield and Loren Suitzer The Effects of RED Tax Credit and Allowances in Canada: Research Policy, Vol 14 (1985).

4 Jeffrey Bernstein and M Ishaq Nadiry Research and Detelopment and Intra-industry Spillocers: An Empirical Application of Dynamic Duality: Review of Economic Studies, Vol $56(1989)$

5. James R. Ilines, No Place like Home, Working Paper No. 4574, National Burean of Economic Research Wasbington DC. 1993; Martin Neil Baily and Robert Z Laurence, Tax Policies for Innotation and Competitive. ness, Council on Research and Technology: Wasbington DC: 1987 .

6. R\&D, Innovation and Comperitiveness - An Evaluation of the Research and Development Tax Concession, Research Repont 50. Bureau of Industrial Economics Canberre, 109 ; 
suggested that it could be substantial. More recent evaluations are less pessimistic, although much depends on the precision of the definition of eligible expenditures and on the effectiveness of administrative and auditing procedures. In the United States, a 1989 study by the Government Accounting Office, based on evidence from Internal Revenue Service auditors, concluded that relabelling does occur but the amount involved is fairly small.

\section{A Comprehensive Approach}

An evaluation of the effectiveness of taxincentives to R\&D must address other issues than the impact on the total volume of business spending on it. Since the impact on R\&D costs vary across firms, are the firms that benefit the most also those who require them most? The evidence, admittedly limited, suggests the answer is negative. And what is the structural impact of taxincentives on national research and innovation systems? How does it affect the number of R\&D performing firms, the orientation and timehorizon of firms' R\&D acivities, the relationships between private firms and public research organisations? That aspect is probably the one which has been the least investigated in the work undertaken to date. In Australia, a study by the Bureau of Industrial Economics (BIE) concluded that the tax-concession did not encourage substantially more firms to do R\&D but was rather more influential in inducing them to make better use of the existing research infrastructure. ${ }^{6}$ In France, on the contrary, the R\&D tax-credit is thought to have helped increase the amount of R\&D undertaken by SMEs.

The effectiveness of R\&D tax-incentives also has to be assessed from a global rather than strictly national perspective. That raises a series of questions on which current knowledge is still poor. First, how effective are such schemes for increasing the absorptive capacity of national economies, so as to maximise national benefits from the international diffusion of technology? Assessment work is generally silent on this issue, except in Australia where the BIE has found that

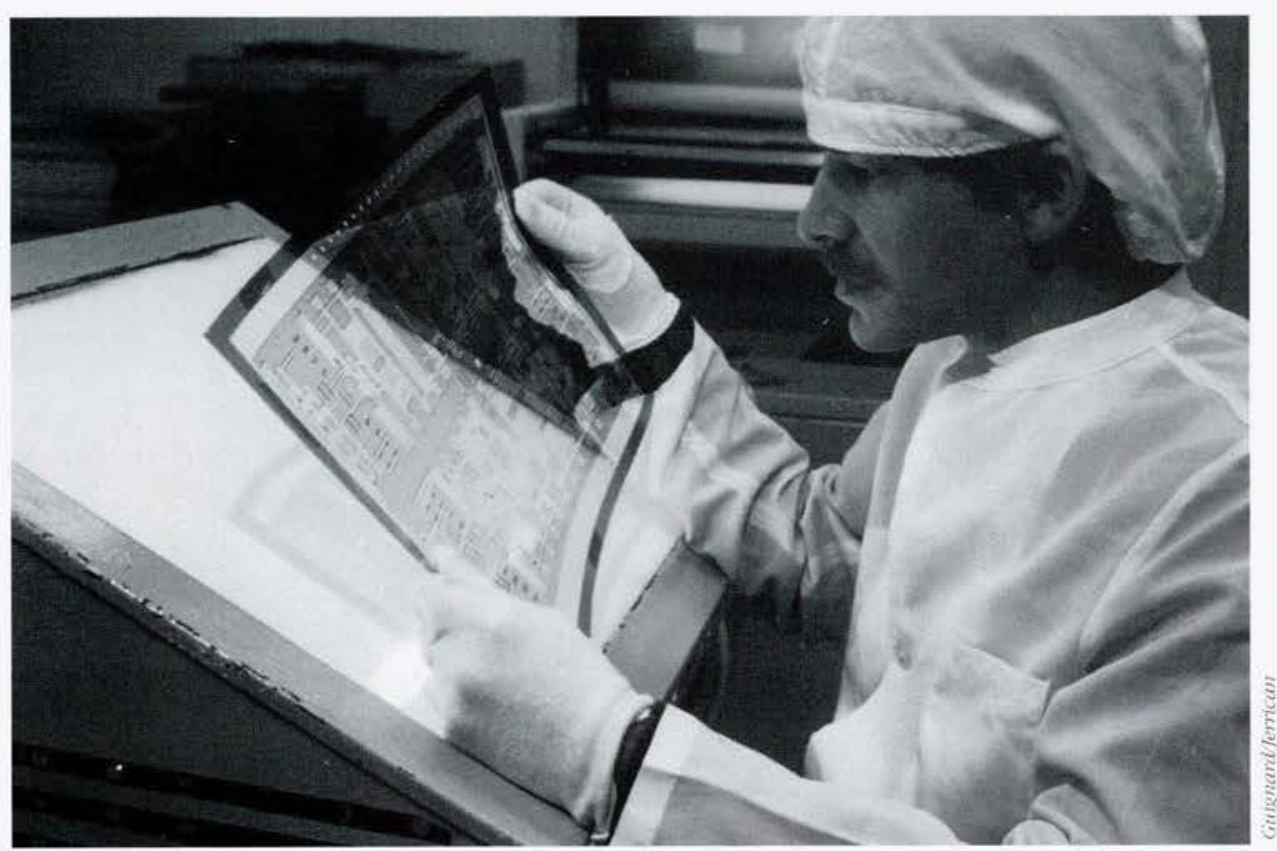

the tax-concession had little influence, compared to size of firm or extent of foreign ownership, on the acquisition of foreign technology and expertise.

Second, is it feasible - or even desirable - to design tax incentives so as to maximise domestic benefits and prevent benefits from spilling over through international innovation networks? In the event, little is known about the effectiveness of imposing requirements of national benefits among the eligibility criteria.

Third, how do R\&D tax-incentives interact with the rest of the tax-system to influence the composition of R\&D investment by multinational firms? This is a complicated issue which has been investigated in the United States, James Hines study found that because of the way that income from foreign sources is taxed, the R\&D tax-credit tends to encourage firms to do R\&D that is targeted for sales in foreign countries; but Hines could not reach a conclusion on how the benefits were distributed.

Last but not least, are firms located in countries which do not offer tax incentives to R\&D (Germany and United Kingdom, for example) at a disadvantage? There is no straightforward answer to this politically hot question. The impact of R\&D tax incentives on firms' competitiveness cannot be isolated from that of the other components of national systems of government support to R\&D and innovation, and of framework conditions, including the tax-system as a whole.

Supporting innovation is an important objective in all countries. Tax-incentives to R\&D are widely used to that end in the OECD area and beyond (in Korea and Singapore, for instance), and often entail sizable public expenditures in terms of revenues forgone (of about $\$ 1$ billion in the United States and FF3.5 billion in France, to take only two examples). Their efficiency is therefore subject to periodic assessment, especially in times of budget stringency or tax reform. The most recent and best-practice studies suggest that they are a relatively efficient tool for increasing the average propensity of firms to spend on R\&D. But these analyses do not help understand how tax-incentives interact with the other element of policies of government support in determining the extent to which, and how, tax-induced additional expenditures on R\&D are translated into innovation and ultimately improved national economic performance and welfare. Such an understanding requires a more systematic approach to policy assessment, as also do international comparisons of the strategies and instruments used in innovation policy. .

\section{OECD BIBLIOGRAPHY}

Science, Technology and Industry Outlook forthcoming 1996

National Systems for Financing Innovation, 1995. 
to parents on child-rearing or conflict-resolution. Educational services must adapt to the learning requirements of the child not only as an individual; they must also recognise the family context.

These problems can manifest themselves in a dramatic manner. A report from Saskatchewan, Canada, for example, notes that "children and young people are coming to school hungry. emotionally and physically abused and neglected. destructive and violent in their behaviour, with physical and learning disabilities, with language and cultural needs, with health or medical needs and suffering from the stress of family breakdown'?

The traditional models of support services have tended to treat the mother, the child or the family from the perspective of the particular profession involved and to deal with problems in isolation from one another. Hospitals may set appointments to meet their own schedules, not taking account of what best suits the family. Schools may be unaware of family crises and thus be insensitive to their impact on a child's school performance, responding perhaps by setting unrealistic homework requirements. Indeed, the way in which services have to account for their funding may of itself stimulate the creation of additional services dedicated to tackling problems out of context. This 'stove-piping' or programmatic approach may well lead to the provision of irrelevant, overlapping or duplicated services; worse, excessive form-filling or professional rivalry can even inhibit the provision of support that is actively required.

Over the past decade it has become increasingly clear that this kind of programmatic structure is ill-adapted to satisfying the demands of the individuals and families it is intended to serve. Furthermore, the services required are often difficult to find or are unavailable. They can lack

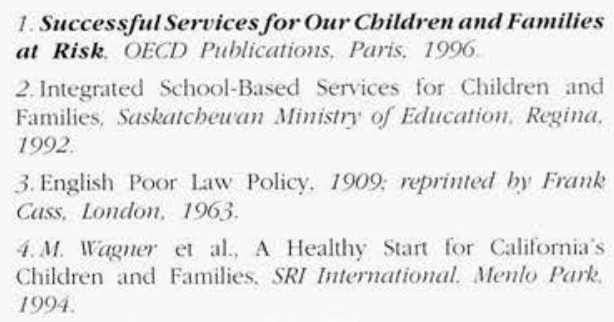

continuity, respond to crises instead of being preventitive and steadily supportive, and they are generally unaccountable to the people they are intended to help. Many countries, encouraged by escalating costs and a trend towards decentralisation, are therefore moving towards a rationalisation of the way services work and in particular are examining their co-ordination in the context of community development.

The idea of co-ordinating social services to meet the requirements of the disadvantaged is not new; indeed, it has been a feature of social policy in countries such as Finland, Germany and the United States for many years. The central idea of prevention, brought about through the co-ordination of the actions of a wide range of community-based agencies in both the public and private sectors was foreshadowed in the United Kingdom, for instance, by the socialist commentators Beatrice and Sidney Webb in the first years of this century. They argued for a principle of prevention' through which the community, by way of a variety of agencies, would address the main causes of destitution 'at the incipient stages, when they are just beginning to affect one or other members of a family, long before a family as a whole has sunk into destitution: Volunteer workers, the Webbs argued, would have a key role together with government: the modern relation between the public authority and the voluntary worker is one of systematically organised partnership under expert direction'?

\section{Co-ordination in Practice}

Services are co-ordinated differently in different countries, and they work differently for children of different ages. But at least it involves the establishment of agreed rules of operation and joint goals and activities, which have implications for vertical and horizontal links in organisational structures and for the personnel involved - and which may also threaten the autonomy of a service.

In many countries, legal and policy frameworks are being set to improve co-ordination across the various strata of the system to improve the efficiency and effectiveness of services by changing the ways in which they work. prevent duplication and to reduce costs (box, p. 28). They may mandate change in strategy (for instance, by the creation of co-ordinating planning bodies), operationally (through the development of local inter-agency committees), or in the field (by the formation of inter-disciplinary case-management teams).

Overcoming legislative barriers, real though unintended, to the integration of services can also be necessary. One such barrier, frequently cited, is derived from rules on confidentiality which prevent professionals in different services from sharing information about clients. In Finland, this problem has been overcome by changing the law to require professionals to share information more widely, though always recognising the importance of respecting the privacy of the individual.

Since co-ordination is an approach that has to respond to customer requirements that can often show enormous local variation - rather than providing a set of pre-determined services - it can take many forms. In California in 1991, for instance, the state legislature enacted the Healthy Start Programme which attempts to bring together public- and private-sector social-welfare, health and educational support-services in schools.

The outcome of this initiative was a number of different responses geared to local conditions. An interim evaluation in $1994^{4}$ identified four separate models: school-based family resource centres; satellite family-service centres; familyservice co-ordination teams; youth-service programmes. These arrangements had their own strengths and weaknesses.

For instance, the school-based family resource centres had an identified space at a school to which families could come for a variety of services. They provided a broad array of services and led to substantial improvements in their customers' mental health. Satellite services involved centres not located in schools, served the fewest people and offered the fewest services - but they did increase access to dental care and showed improvements in mental health. Family-service co-ordination teams, by contrast, 


\section{Co-ordinating Services for Children at Risk}

\section{FOCUS}

\section{Co-ordination v. Isolated Programmes}

A Co-ordinated Service
- is cuslomer-driven
- is family-oriented
- is driven by the search
for a satisfactory outcome
- seeks balance between prevention
and intervention
- is decentralised
- uses multi-agency funding including
private sources
- provides co-ordinated services
- is evaluated by outcomes
- is community-based
- services are delivered tbrough teams
of professionals, parents
and non-professionals
- seeks institutional change

Source: adapted from Judy Chynoueth. Foundation Consortium for School-linked Services, Sacramento, California, 1994

were not based around a physical location. They featured teams of professionals who assessed the goals and demands of students or families and developed strategies to meet them. School personnel were often heavily involved in this approach. This model was associated with the strongest emphasis on academic services and produced genuine advances in students' educational performance. Youth service programmes addressed the health, education and social wants of adolescents and were either arranged around a clinic based in or linked to a school or made a broad array of services available to clients. These programmes were associated with the strongest emphasis on health screenings and medical services and with marked increases in the users' employment status.

\section{Advantages and Disadvantages}

The advantages of co-ordination can be identified at all tiers of the system by administrators, professionals and clients alike. For administrators, for example, benefits are perceived in staff morale, in costs and effectiveness. Programme administrators in 13 countries examined Belgium, Canada, Finland, France, Germany, Italy, the Netherlands, Portugal, Slovenia, Sweden, Turkey, the United Kingdom and the United States - agreed that co-ordinating services reduces costs and improves results. For middle managers and professionals (medical staff, teachers and social workers, for instance), there are both personal and professional benefits. Professionals, for example, found their work more satisfying, more interesting and less stressful, and they could reach more clients and achieve better results. Teachers benefit from improvements in students' readiness to learn, and their participation in activities which are not strictly educational (the discussion of students' social problems, for example). And they are able to develop better-rounded relationships with the students,

Contacts between professionals likewise improve, since an increased understanding of the roles and responsibilities of others can develop. In Portugal, professionals are working with children who spend most of the day living on the street. Community-based, integrated pro- grammes in Lisbon, for instance, bring together teachers, social and health workers, the police and employers in an effort to take education to these children and re-unite them with their families and, for the older students, help find them jobs.

The involvement of the local communities can strengthen the delivery of services as well as stimulate trans-generational education. Parents, for example, can benefit from integrated projects by taking advantage of resources such as school facilities, improving their own knowledge and self-esteem through contact with professionals, even obtaining employment as members of staff. In Kansas City, Missouri, for instance, parent classes in child development offered by the Family Focus Centre have led to improvements in the way the parents interact with their children.

The professionals also note that casemanagement involving multi-disciplinary teams improves services, since they are then more comprehensive and respond better to children's requirements; they are, moreover, preventitive rather than crisis-driven. In addition, casemanagers who are 'generalists' stigmatise their clients less than specialists.

'One-stop shops' for social services are also now viewed as being more accessible and convenient for clients because they provide a single entry-point for receiving information, making applications and providing services. Services can also be allocated more quickly and efficiently. In Australia, Youth Access Centres bring together a range of services in local employment offices and use case-management to help disadvantaged young people to find jobs.

Evaluations of specific attempts to co-ordinate services have tended to focus on how successfully they cater for their clients and on the process by which the service is developed. Clients are reported to benefit in terms of school attendance, achievement, employment and health. In Germany and the Netherlands, for example, there have been substantial efforts to co-ordinate services to help problematic young people in the transition to work, with evaluations demonstrating the success of the approach. The evaluations underline the importance of both agreeing that change is necessary and actually 


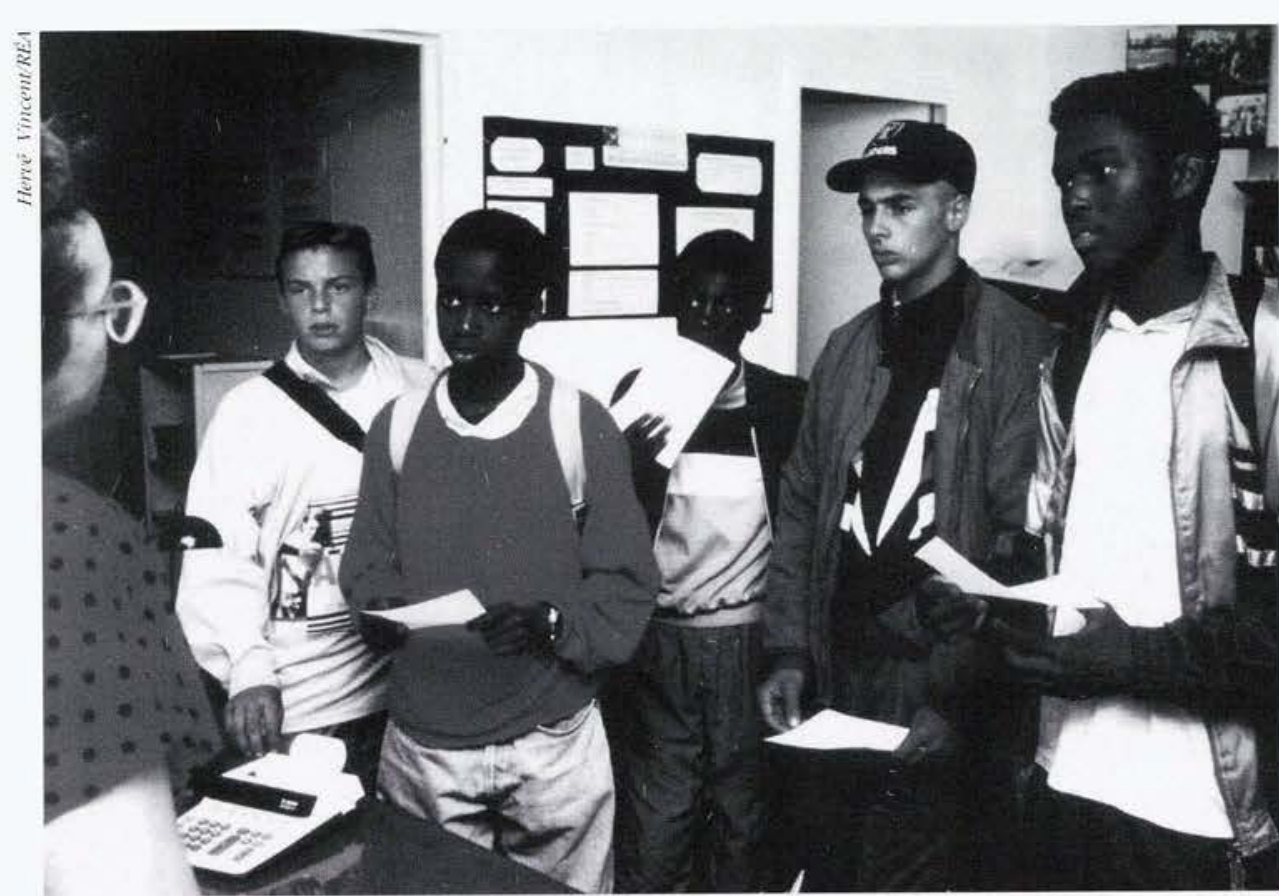

The programmatic approach that required 'clients' to present themselves in agencies is giving way to community-based delivery of services.

implementing it in the structure of the organisation of the services, of widespread participation, of leadership and of time in developing new forms of support mechanisms.

But change also brings concerns. Administrators are worried mainly that lack of time might mean an incomplete re-alignment of services, leading to duplication, an increased workload and bureaucracy. They also express worries that their staff may demand better jobs and pay. These misgivings are reinforced by the professionals who also fear loss of professional identity and independence, a reduction in their ability to specialise, even potential job losses. They also fear that communication may be difficult, that workloads may increase and that the resources required to achieve effective co-ordination may not be forthcoming. These concerns seem fully justified: in many cases countries have sought to stimulate change with the simple expedient of giving grants to provide consultants.

These trends are forcing schools to look outwards for support in dealing with pupils at risk. In the past the co-ordination of health and social services has been relatively common. The involvement of education, by contrast, is a relatively new endeavour brought about by the growing complexity of the challenges faced by schools, changing views on child development and the breakdown of traditional family life.

Government policies encouraging decentralisation certainly appear to set favourable conditions. Indeed, decentralisation appears to be a sine qua non of effective co-ordination, since it allows for more flexibility in service delivery and the involvement of the public, private and voluntary sectors of local communities.

Too often now schools are finding it difficult to cope on their own with the social problems from which more and more young people are suffering. Co-operation between schools and other services is thus becoming ever more important for educational success of a large group of students and for improved efficiency and standards in the system as a whole. Too often there is a mis-match between the services pro- vided and those required by the children and families they are intended to serve. Integrating and co-ordinating these services could make a substantial contribution to alleviating the pressures they currently feel.

The decentralisation of decision-making from central government should allow communities to become more involved in the organisation of the services that directly affect them. It may also open up opportunites for additional support from business and interested individuals. Yet the radical overhaul of the delivery mechanisms involved will mean adaptation by governments, not least of their relationships with local communities and the professions; it is also important that they deal with the 'turf disputes' that will occur. Centralgovernment departments which are funding services and bear responsibility for them will wish to control the policies bearing on them. And that will clash with the desire of local communities to control the innovations.

Policies which are tied to the professions and their unionised interests may lose contact with the requirements of the customers of an integrated service. And there could be battles over turf also between professionals whose roles and responsibilities are changing. Multi-disciplinary training for the administrators and professionals working in these new arrangements is clearly essential - but currently it is largely lacking. Moreover, the development of a different form of service-delivery will call for financial support over the short, medium and long term - possibly in conflict with the constraints imposed by budget pressure. $=$

\section{OECD BIBLIOGRAPHY}

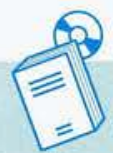

Successful Services for Our Children and Families at Risk, 1996

Our Children at Risk, 1995

Peter Evans, Tacking Educational Disadvantage', The OECD Observer, No. 186, February/March 1994. 


\section{The Transformation of Baltic Agriculture}

Andrzej Kwiecinski and Vaclav Vojtech

The agricultural sector in the three Baltic republics - Estonia, Latvia and Lithuania - is emerging from an awkward period of reform well placed to face the realities of world markets. But there are enduring difficulties still to be overcome in privatisation, in eliminating inefficiencies in the production and processing of foodstuffs, and in reducing pressures for price-support policies that lead to economic distortions. ${ }^{1}$

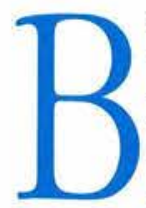
etween the end of the Second World War and the advent of independence in 1990-91, the agricultural sectors in Estonia, Latvia and Lithuania were progressively integrated into the centralised economy of the Soviet Union. Soviet agricultural policy was focused on maximising production so as to guarantee a supply of cheap food to the major urban centres of the USSR - a very expensive policy, both in its budgetary cost and the extent to which it resulted in the misallocation of resources. It also imposed a framework of regional specialisation, within which the three countries were required to supply other regions, in particular Leningrad (St Petersburg) and Moscow, with livestock products.

After regaining independence, the Baltic countries started to rebuild the basic legal structures and institutions for the operation of a democratic political system and a market economy. All three adopted the 'shock therapy' approach to macroeconomic reform, liberalising domestic prices and foreign trade, strongly devaluing local curren-

Andrzej Kwiecinski and Vaclav Voitech work in the Economies in Transition Division of the OECD Directorate for Food, Agriculture and Fisheries. cies and imposing tight fiscal and monetary policies. Privatisation and the restitution of property rights were central elements of micro-economic reform. Accompanying these systemic changes was a sharp decline in GDP at the beginning of the transition, but by 1994-95 the downward trend in the economic output had bottomed out

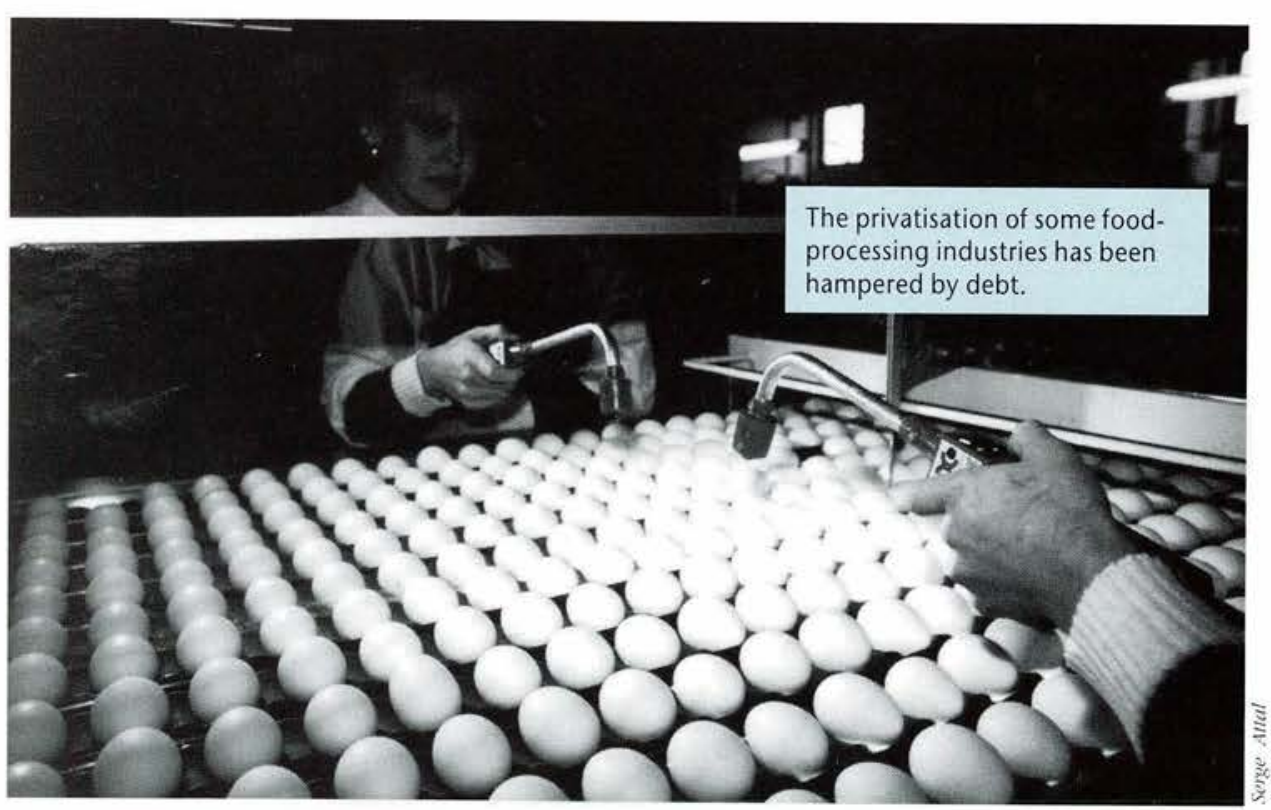

across the region. Indeed, in 1995, GDP increased in Estonia and Lithuania, while it was stagnant in Latvia.

Agriculture plays an important role in the three economies (Table 1), accounting for about $8-9 \%$ of GDP and between 7 and $24 \%$ of total employment. Between 1989 and 1995 agricultural output, which was more or less halved, fell more sharply than non-agricultural output. In spite of this fall in output, employment in agriculture increased in Latvia and Lithuania, indicating that the agricultural sector acted as a buffer against unemployment during the transition. This resulted in a substantial fall in the productivity of agricultural labour in Latvia and Lithuania, while in Estonia, where agricultural employment fell, it remained relatively high.

For nearly five decades, the agro-food sector in the Baltic countries was largely state-owned and almost all agricultural land was operated as 
either collective or state farms. As in the rest of the economy, the main elements of the restructuring process were privatisation and restitution of former ownership rights as a means of increasing efficiency.

The new farming structures are still evolving and vary across the three countries, reflecting their differing approaches to land reform. The Estonian government did not favour any particular type of farm structure, whereas Lithuanian and Latvian authorities showed a clearer preference for medium-sized family farms. Large-scale farms are predominant in Estonia and operate on about $60 \%$ of agricultural land (Table 2 ), with household plots and family farms occupying the remainder. The 360 former collective and state farms have been transformed into about 1,000 farming enterprises producing mainly grains and milk. Although they are still largescale, their smaller size has made them more manageable than their predecessors. Moreover, there are a further 13,500 family farms with an average size of 23 hectares, of which about seven hectares is forest.

In Latvia, restitution and privatisation have encouraged the emergence of family-type farms. In order to promote this type of farming, similar to the pre-war structure, any approved application for land, whether for restitution to previous owners or for a new individual farm, had a higher priority than continuing use of the land by a collective or state farm. As a result, individual farms and household plots are now the comerstone of Latvian agriculture, operating on over $80 \%$ of agricultural land with an average size of 20 hectares per family farm. In addition to some 120 reformed state or collective farms, new corporate farms were established by individuals using privatised land and non-land assets. At the beginning of 1995 , some 464 new corporate farms were in operation. Both old and new corporate farms were operating on $17 \%$ of the agricultural land available.

In Lithuania there are now three broad groups: small, medium and large-scale farms. In 1995,

1. Review of Agricultural Policies: Estonia, Review of Agricultural Policies: Latvia and Review of Agricultural Policies: Litbuania. OECD Publications. Paris, forthcoming 1996 almost a third of all agricultural land was farmed by 2,340 large agricultural companies, with an average operating size of 451 hectares. In addition, there were 135,000 individual farms which accounted for $34 \%$ of all agricultural land. The average farm size of individual farms, at 8.4 hectares, is small. Household plots (plots less than 3 hectares) accounted for the remainder and, despite their small size, produce about half of all crops and about a third of livestock products in Lithuania.

Difficulties have arisen in establishing proper legal titles in all three countries, with many conflicts occurring between new owners and those who had worked the land during the Soviet period. The rather complicated procedures for land registration and the lack of qualified staff to carry out the necessary surveying and mapping operations have contributed to the slow pace of privatisation and restitution of land.

In Estonia, for example, only $20 \%$ of agricultural land is not subject to major disputes between previous owners and current operators of land and buildings. A further $30 \%$ is subject to contradictory claims that will not be easy to resolve. and the remaining $50 \%$ is still owned by the state because previous owners have not exercised their claims. As a result, only $9 \%$ of agricultural land was registered in the 'Title Book' (the land registry) by the end of 1995 and could therefore be considered as fully privatised. In Lithuania, full ownership titles, accounting for $40 \%$ of the agricultural land area, have been restored to about 74,000 farmers; in Latvia the corresponding percentage was $20-30 \%$ at the end of 1995 .

The degree of privatisation in the industries supplying inputs (the 'upstream' sector) and in processing and trading industries (the 'downstream' sector) varies widely across the three countries. Privatisation was virtually complete in Esto- nia and Latvia by the end of 1995 , whereas in Lithuania only about two-thirds of the upstream and downstream sectors were in private hands. The meat- and poultry-processing plants have proved to be very difficult to privatise because of the heavy burden of outstanding debt, outdated processing facilities and shrinking demand, resulting in under-utilisation of capacity.

In all three countries, preferential treatment in privatising the agro-food industries was given to farmers so as to promote vertical integration in the food chain, thus to a certain extent crowding out foreign investment. There is some anecdotal evidence that this approach speeded up privatisation in the downstream sector, especially in Lithuania. But it has had a downside: there have been delays in the restructuring of downstream enterprises and the introduction of gains in efficiency, which can be linked to the lack of capital and of technical, marketing and business skills of local agricultural producers. These delays have contributed to the depressed prices received by farmers.

\begin{tabular}{|c|c|c|c|}
\hline & $\begin{array}{l}\text { Small forms: } \\
\text { under } 3 \text { hectares }\end{array}$ & $\begin{array}{l}\text { Medium farms: } \\
\text { 3-100 hectares }\end{array}$ & $\begin{array}{l}\text { Large farms: } \\
\text { over } 100 \text { hectares }\end{array}$ \\
\hline Estonia & 25 & 15 & 60 \\
\hline Latvia & $23^{7}$ & $58^{\circ}$ & 19 \\
\hline Lithuania & 33 & 32 & 35 \\
\hline
\end{tabular}




\section{The Transformation of Baltic Agriculture}

\section{FOCUS}

\section{Trends in Trade since Independence}

\author{
Michael Ryan
}

During the Soviet era, Estonia, Latvia and Litbuania were substantial exporters of agricultural products, especially dairy and meat. and importers of agricultural inpuls sucb as animal feedstuffs and energy. All trade was regulated by the state monopoly and was largely confined to exchange between regions within the Soviet Union. The collapse of the Soviet Union led to the disappearance of the traditional network and markets for agricultural products from the Baltic countries. With independence in 1990-91 they bad to develop their oun trading regimes with the rest of the world and therefore faced the enormous task of establishing new arrangements. institutions, transport and marketing infrastructures

From 1991 to 1993 the policies governing the agricultural trade of Latvia and Lithuania were based on non-tariff barriers (such as import and export quotas, licenses and periodic bans on exports and imports). More consistent and coherent policies were adopted in 1994 when most administratice restrictions were replaced by tariff-based border protection, and the new trade regimes were brought more in line with world market conditions. Estonia. by contrast, adopted open trade from independence

Although the Baltic states are net agricultural exporters, Latvia became a net importer of meat and dairy products in 1994 because of a temporary dislocation in livestock production. The composition of exports and imports is very similar for all three, with exports consisting mainly of commodity-type products and imports largely made up of processed foods with bigh value-added. For Lithuania in particular, an increasing share of food exports consists of reexports.

In addition to sales of enterprises for cash, all three countries have made wide use of investment and or compensation vouchers in the privatisation of the agro-food sector. ${ }^{2}$ In spite of the preference given to local farmers, foreign investment has nevertheless played an important role in restructuring and privatising agro-food enterprises in Estonia.
The share of agricultural and food products in the exports of the Baltic countries bas fluctuated considerably over the last five years. falling from over a quarter in 1991 to less than a fifth in 1995. A large part of this fall was due to reduced exports to the former Soviet Union. especially during 1991-93. These exports started to increase again in 1994 and 1995. reflecting to some extent the re-establishment of traditional trading links. In the period 1991-95, agricultural and food products represented less than $10 \%$ of lotal imports to both Latvia and Lithuania but almost $16 \%$ for Estonia.

Estonia, Latvia and Lithuania bave signed bilateral trade agreements with many OECD countries, as well as with other central and eastern European countries and former Soviet republics. Moreover, Free Trade Agreements with the European Union came into force in Jantiary 1995, and gave preferential treatment to trade between the Baltic states and the EU countries. In July 1995, all three countries signed Association Agreements with the EU. These agreements provide important market opportunities, especially for agricultural products - but the Baltic republics bave found it extremely difficult to fill many of the product quotas because of difficulties in meeting certification standards.

A free-trade agreement in industrial products was signed between the Baltic states in 1994, although it was June 1996 before they reached an agreement on agricultural products. As a result, all custom duties on trade in agricultural products bas now been abolished provided the goods are produced in one of the Baltic countries. All three of them are currently in the process of negotiating accession to the World Trade Organisation (WTO). For trade with Russia. Latvia and Lithuania have benefited from 'most favoured nation' (MFN) tariff status since January 1995; Russian trade with Estonia is still subject to tariffs that are double the MFN rates.

One of the main developments in the Baltic republics bas been the shift toward western

After independence, the Baltic states abolished most of the regulations and controls that existed during the Soviet era. As a result, the prices of agricultural inputs, in particular energy and fertilisers, rose to those prevailing in world markets, while the prices that farmers obtained for their output increased more slowly. A severe cost-price squeeze followed, biting especially markets, especially for imports of agricultural and food products. In 1994, for example, the EU accounted for $41 \%$ of imports of Estonian agricultural and food products, and almost $15 \%$ of Estonian exports went to the EU. The former Soviet Union, by contrast, absorbed over $70 \%$ of Estonian exports, but provided less than $10 \%$ of imports. For Latvia, the main export market is also the former Sotiet Union, which accounted for over $80 \%$ of total exports and $15 \%$ of imports Trade with the EU is increasing steadily: oter $60 \%$ of imports and almost $14 \%$ of exports in 1995. The EU likewise accounted for oter threefifths of Lithuanian imports and almost onethird of Lithuanian exports in 1995. On the other band, imports into Litbuania of foodstuffs from the former Soviet Union fell to 16\% while exports increased to $55 \%$

A more coherent framework on agricultural trade policies has been implemented and trade patterns are beginning to stabilise in the Baltic countries. Many outstanding problems nonetheless remain to be resolved. The process of accession to the WTO will belp to overcome some of them, especially those derived from tariff bindings (which improve discipline and procedures for the application of tariffs) and customs valuation procedures (which monitor trade on the border). With the return of grouth to the Baltic republics, trade in agricultural and food products is likely to increase in the coming years especially for bigh value-added food products (not least consumer-ready' ones such as $T 7$ dinners). The main challenge will be improving quality and bygiene standards, developing the transport infrastructure and trading links. in addition 10 dealing with the rather cumbersome bureaucratic barriers in many of the importing countries - including some in the EU and OECD.

Michael Ryan works in the Economies in Transition Division of the OECD Directorate for Food. Agriculture and Fisheries.

hard in 1991-93. Output prices have increased more rapidly since then, thereby improving agricultural terms of trade.

The degree of support for agricultural producers in the three countries, as measured by the Producer Subsidy Equivalent (PSE), shows that support can be largely divided into three periods (Figure). The period of Soviet dominance 
between 1986 and 1990 was characterised by high support of market prices and an average net percentage PSE of about $70-80 \%$. The second period between 1991 and 1993 was the time of the major macro-economic reforms and dramatic, sometimes chaotic, adjustments which resulted in a substantial 'implicit' taxation of agriculture, particularly in Lithuania, by keeping farmgate prices lower than those at the border. In the period 1994-95 a more stabilised macro-economic framework and adjustment process helped to reduce this implicit taxation on farmers to about zero in Estonia and Latvia. On the other hand, in Lithuania, price support, storage and export subsidies were introduced in 1995 for major agricultural products and resulted in a rise in the average net percentage PSE to $13 \%$.

During the Soviet period, the average degree of support in the Baltic countries was substantially higher than in OECD countries. But in the 1990 s it declined sharply and by 1994-95 was significantly below the $\mathrm{OECD}$ average of $42 \%$, and below the average in other central and eastern European countries (the Czech Republic, Hungary and Poland). In Estonia and Latvia, the degree of support was even below those OECD

2. All countries applied slightly different approaches for distributing imestment and compensation vouchers. In general, investment touchers were distributed to all citizens depending on numbers of years worked ( in Estonia and Litbuania) or on the number of years of residency (Latvia); compensatory vouchers were given to previous ouners ubose property could not be returned in physical form.

3. The total Producer Subsidy Equitalemt is an indicator of the total value of the monetary transfers to agricultural producers resulting from agricultural policies in a given year. Botb transfers from consumers of agricultural products and transfers from taxpavers are included. The percentage PSE is an indicator of the value of transfers as a percentage of gross farm retentes. countries with the lowest rates of measured support (New Zealand and Australia).

불

In view of the difficulties of restructuring and re-orienting their agriculture and agro-food industries from the previous Soviet system towards an efficient, more market-oriented mode of operation, the Baltic countries have made substantial progress. Their farming sectors now have the potential to develop as internationally competitive sectors. Nonetheless, there remain still some difficulties to be resolved in land reform (not least the very slow process of restitution, which is hampering the whole process of land privatisation and discouraging investment). Moreover, the special preferences given to agricultural producers in privatising agro-food industries tend to slow down the restructuring process. In the new market-oriented environment it will be essential to develop appropriate education and training for managers of large agricultural enterprises and for individual farmers so as to help them overcome their lack of business-management and marketing skills.

The difficulties experienced by the farming sector in the first stage of transition resulted in strong political pressures in all three countries to provide more support to agriculture. As a result, in Latvia, tariffs on food imports were introduced as early as 1992. In Lithuania, price support was increased considerably in 1995. Even in Estonia, where the government was able to resist such pressure for a long time, several regulations have been passed by parliament which may result in a significant increase in market price support. Further elimination of inefficiencies in the food chain through structural and institutional reform and anti-monopoly and anti-trust actions would benefit farmers and help reduce the pressure for economically distortive measures of price support. Policies should therefore be focused on reducing inefficiencies in the foodprocessing industries and on developing rural and local development measures that facilitate adjustment in the agricultural sector.

\section{OECD BIBLIOGRAPHY}

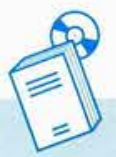

Review of Agricultural Policies: Estonia, forthcoming 1996

Review of Agricultural Policies: Latvia, forthcoming 1996

Review of Agricultural Policies: Lithuania, forthcoming 1996

Agricultural Policies, Markets and Trade in Transition Economies: Monitoring and Evaluation 1996, 1996. 


\section{The Internationalisation}

Yu Kameoka

The international setting for universities and other institutions of higher education is changing rapidly, both economically and socially. In most OECD countries new developments, not least the globalisation of the economy, have led to more international practices and approaches to the teaching of under-graduates. But the responses from universities and other institutions have not been systematic, and the underlying implications for reform have not been assessed coherently. The OECD Centre for Educational Research and Innovation has conducted a study on the impact of international settings on higher-education programmes and structures. ${ }^{1}$

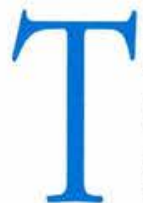

he international dimension of higher education is now given more prominence than in previous decades, for reasons both external and internal. External considerations include changes in the labour market, which call for different kinds of skills and knowledge, not least a deeper understanding of the languages, cultures and business methods found elsewhere in the world. A recent case-study of US-based international enterprises, for example, suggests that employers do see the recent emphasis on multiculturalism and diversity in college curricula as an important preparation for work in an economy without borders. ${ }^{2}$

Governments, too, are increasingly looking on higher education as playing a part in their wider policy objectives, many of which now have a strong international emphasis, from broad foreign-policy interests to more specific concerns of domestic economic development, and all of which can be served by the expertise and resources found in higher education.

Yu Kameoka worked, until recently, on the internationalisation of education in the Centre for Educational Research and Innovation at the OECD Directorate for Education, Employment, Labour and Social Affairs.
One of the most important changes is the increasingly international role of higher education in regional groupings of countries - the European Union, the North American Free Trade Association, Asia Pacific Economic Co-operation (APEC) and so on - rather than broadly 'global' contexts. The evolution of more cohesive regional political and economic arrangements has fuelled schemes aimed at promoting mobility and exchange inside a given region (the 'Erasmus' and 'Comett' programmes of the EU and the 'Nordplus' programme among Nordic countries are obvious examples, and there are similar initiatives in North America and the Asia-Pacific area). Such schemes could also help improve comparability in the contents and methods of study programmes.

From within, there has been a re-assertion of the 'traditional' view of higher education. First, there is the long-standing interest in establishing and maintaining an environment of discovery and advanced learning in which the scope of knowledge is continuously expanded through exchange among scholars and students around the world. Environmental concerns and international conflicts are making institutions of higher education more aware of the importance of finding multilateral solutions. There is also the prag- matic concern to excel in research, to maintain adequately staffed faculties and to obtain efficient enrolment rates in institutions and individual programmes of study. These trends increase the importance of the international dimension of higher education in the contents and methods of study-programmes, the conduct and orientation of research and the structure and administration of institutions.

Whether seen as a response to external forces or as a desirable reinforcement and elaboration of the 'traditional', universal orientation of the university, the key word encompassing new ideas seems to be 'internationalisation'. But it is now seen to extend far beyond specialised international programmes and student exchange, which were the hallmarks of the past twenty years or so. Indeed, it has moved into the mainstream of the curriculum and administrative structure at many universities and is expected to expand well into the next century. What it means in practice is that the concept should be widened to include, in addition to student mobility, also curriculum and staff development and mobility, and specific institutional strategies to adapt to and benefit from internationalisation. The evolution of information technology is also expected to play a role as software transfers complement (or substitute for) student mobility.

\section{What Curricular Changes?}

The internationalisation of the curriculum demonstrates the progress of higher-education institutions. After a first period of individual student mobility ('free movers') and a second phase of mobility and exchange based on institutional agreements, an internationalisation of academic content and processes - where education is sometimes provided by foreign academics - is taking place. That is likely to have a more structural and longer-term impact on the institution itself, whereas the effects of mere mobility and exchange are limited to the individual students. The international dimension is thus no longer a marginal concern affecting the $5-10 \%$ of students who actually move between 


\section{of Higher Education}

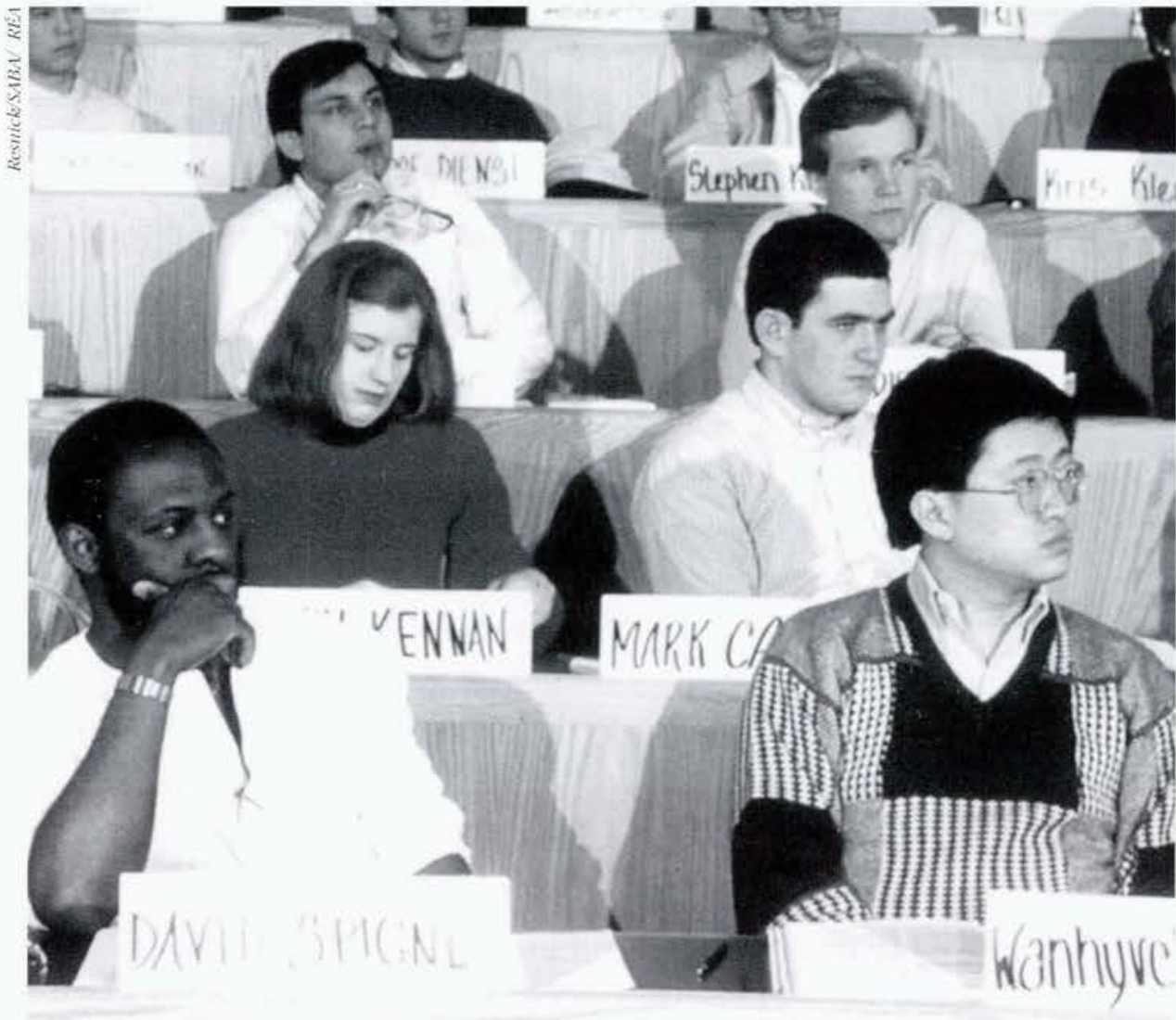

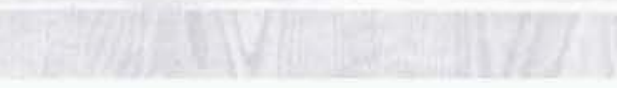

institutions; it has gained its place as a more central concern of mainstream educational planning and management.

To discover how much higher-education institutions have responded to these changes, the OECD Centre for Educational Research and Innovation recently conducted a study on new curriculum initiatives in Australia, Denmark, France, Germany, Japan and the Netherlands. Defining internationalised curricula as those with an international orientation in content, aimed at preparing students for performing (professionally/socially) in an international and multicultural context, and designed for domestic students and/ or foreign students', the study, synthesised by Marijk van der Wende of the Netherlands Organisation for International Co-operation in Higher Education, has identified a diverse and increasing range of activities.
These initiatives are largely based on institutions' strong perceptions of the desirability of internationally trained professionals, who are able to address cross-border and global problems from an international and interdisciplinary perspective and to work with people from Australian university aims to train managers so they can understand and undertake business in the fast-growing economies of the Asia-Pacific rim. Another, in the Netherlands, aims to enable its graduates to tackle legal problems that have a cross-border character (such as environmental law), that are treated under international law systems or involve international clients or colleagues by encouraging flexibility in thinking and problem-solving skills within the context of different legal systems. And a school of international studies in Japan has recognised different national and cultural backgrounds. One that the revolution in communications techno$\operatorname{logy}$ is helping to create an interdependent 'global village', which will require the services of men and women with a broad knowledge of other lands and societies. Paradoxically, though, and in spite of such perceptions, in the majority of cases no outside consultation - as, for example, with experts from business or other industries - took place as these programmes were being developed.

From a more pragmatic point of view, the decision to reform the curriculum has two advantages. It provides international educational opportunities for domestic students who are not mobile. And it also increases the attractiveness of the curriculum for foreign students, whose presence is usually beneficial to domestic students and to the education process as a whole. Indeed, a wider international or comparative element to the curriculum enables foreign students to study in an international group, often with the curriculum made more accessible by being taught in a language other than the national tongue (as in Denmark, Japan and the Netherlands, for example).

There is a strong relation between the internationalised curriculum and the mobility of students and staff. Student mobility seems to follow several different patterns. Many programmes contain a compulsory period to be spent abroad. Sometimes a full cohort of students (often in groups of 30 or 50 ) is exchanged with a similar cohort from a partner institution. Some programmes are open to both domestic and foreign students, who study together in a typical international classroom.

Staff mobility likewise falls into a variety of patterns. For example, some internationalised curricula are taught by visiting international staffs, occasionally in combination with local teachers; others are taught by local staff with a strong

\footnotetext{
1. Internationalisation of Higher Education, $O E C D$ Publications, Paris, fortbcoming 1996.

2. What Employers Expect of College Graduates: International Knowledge and Second Language Skills, Education Research Report, Office of Educational Research and Improtement, US Department of Education. Washington DC, 1994

3. Danielle Colardyn and Mariame Durand-Droubin, Recognising Skills and Qualifications; The OECD
} Observer: No. 193. April May 1995 


\section{The Internationalisation of Higher Education}

\section{FOCUS}

\section{Liberalising Trade in Professional Services}

Progress in internationalisation of bigher education will also be affected by the liberalisation of trade in professional services, a sector of growing importance. The lack of recognition of foreign qualification and competences is one of the most important obstacles in liberalising trade in professional services, since it often requires foreign professionals to retrain locally for lengthy periods. With the aim of facilitating the world trade in services, work is already underway at the OECD to lower such structural barriers to non-domestic providers of such services. The outcome will bave an impact on the bighereducation institutions which play a major role in training professionals. In disciplines such as accounting, arcbitecture, law, and engineering it is already becoming a pressing issue and the question of international standards for the profession and recognition of degrees as they are related to trade in knowledge-based services therefore has to be addressed.

Assuring the quality of internationalised programmes is another issue. At present. teaching is initiated, arranged and organised largely by individual institutions. But it frequently escapes routine evaluation and accreditation procedures applied to domestic academic programmes. Foreign students who apply to enrol in such programmes require more transparency to make better-informed choices. The rapid expansion of the international aspects of higher education points to the desirability of a common set of criteria, where concerns about the quality of programmes, the use of new technologies and the obstacles to trade in professional services are brought together.

international orientation. Sometimes the curriculum is developed jointly by two or more partner institutions from different countries and is taught by staff circulating among the institutions where it is taught. This kind of programme could lead to a double degree (two diplomas awarded simultaneously but separately by the two institutions) or a joint degree (two or more institutions together award a single degree from a joint programme) being offered. These arrangements are found more often in Europe than in the AsiaPacific region, in part because of the intensive co-operation structures supported by the EU programmes.

In many cases the argument for the new initiatives explicitly referred to improvement of the quality of higher education, with benefits in student motivation and learning, through increased understanding of the international aspects of the subjects, foreign-language competence and intercultural communication skills. The effects of internationalised curricula are strongly related to the involvement of foreign students and staff.

\section{Organisational Impact}

The new international setting poses new challenges for the organisation and management of higher education as well. Services have to be adapted to accommodate co-operative arrangements with 'partner' institutions or faculties in other countries: financing, accounting and legal services for teaching and research arrangements; housing services for foreign students as well as visiting academic and research staff; guidance and counselling for foreign students; support services for the preparation and evaluation of transcripts and records.

The adaptations required by the new international setting are best developed as part of an institution-wide approach: specific, targeted support for administrative and faculty responses is a necessary condition for success, and in three main forms. First, a strong innovator/leader is

\footnotetext{
1. See also Hans de Wit (ed.). Strategies for Internationalisation of Higher Education: A Comparative Study of Australia, Canada, Europe and the United States, European Association for International Education in co-operation with the $O E C D$ and the Association of International Education Administrators, Amsterdam. 1995.

5. Edwin Letwen and Alhert Tuijnman, life-tong Leaming: Wbo Pays?: The OECD Observer, No. 199, April May 1996
}

necessary to provide the impetus for change. Second, the institution must supply the necessary resources (preferably reinforced by national budget allocations and policy framework). Third, there must be strong staff involvement and commitment. If any one of these three factors is missing, the changes will not be sustainable or realise the potential benefits for the participants.

Much of the progress in internalisation to date has been supported by policies and programmes of governments and supranational institutions (such as the EU), which have enabled or facilitated particular pilot initiatives. The environment may be less supportive in the future - at least in financial terms. In many cases it is not clear how viable these programmes will be when less funding is available, for those curricula for which no supplementary resources from students can be obtained. ${ }^{5}$ Many internationalised curricula have clearly not been fully institutionalised as one of the essential functions of the establishment.

The main recommendation for policymakers is that further stimulation of internationalisation is still necessary both through national and supranational policies and programmes and regional, national and supra-national support structures. Internationalisation should also involve active participation by stakeholders from government, the private sector, the community, and voluntary organisations in its development..

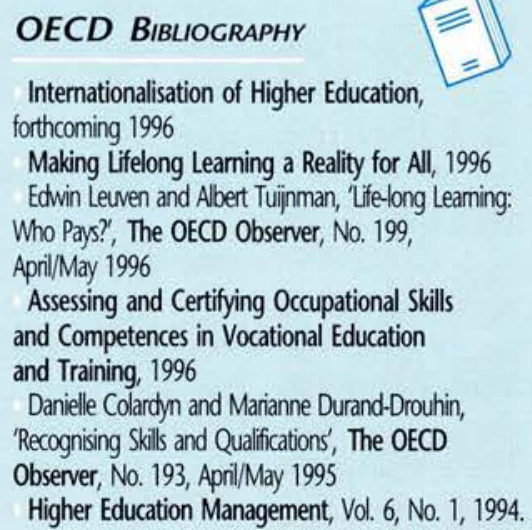




\section{Educational and Career Guidance: What Works}

Caroline St John-Brooks

Good career guidance could have a central role to play in active labour-market policies, which in many OECD countries have to become more effective, ${ }^{1}$ as well as enabling more individuals to lead satisfying and productive lives. But its importance goes largely unrecognised by national policy-makers. The resources currently invested are often not being used as efficiently as they might be, because of a lack of focus on objectives, and systems which are either inflexible and bureaucratic or full of gaps and inconsistencies.

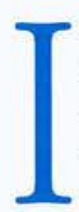
$\mathrm{n}$ the past, most transitions between different tiers of education, or between education and work, happened more or less automatically - as young people moved en masse from one system to another. Career guidance was seen as necessary only for problem cases. But under the pressures of global economic competition, these systems are beginning to become fragmented and more complex - and the relationship between them is much less clear. For many young people, finding an appropriate career path is becoming harder. And adults are increasingly aware that their hard-won skills will have to be regularly added to and updated in a process of life-long learning, sometimes requiring a real effort. ${ }^{2}$

The public seem to have recognised these problems ahead of the politicians: a recent survey carried out in $12 \mathrm{OECD}$ countries for the OECD suggested that more than $80 \%$ of the popu-

Caroline St John-Brooks works in the Centre for Educational Research and Innovation of the OECD Directorate for Education, Employment, Labour and Social Affairs. lation thought that advice and guidance on careers was an 'essential' or 'very important' role of the school. ${ }^{3}$ Curricula are becoming more differentiated to cater for a wider range of abilities and aspirations - and to reflect changes in the labour market. Employers are increasingly looking for flexible and autonomous workers with a sound general education who can train and retrain to meet changing demands.

Until recently, most policy-makers - when they considered it at all - saw educational and career guidance as a way of improving the 'fit' between the skills and ambitions of individuals entering the labour market, and the jobs and occupations available to them. But a revolution is currently taking place in the nature of work, and this model, although it still has a role to play, looks increasingly simple-minded.

In the future, more and more individuals will have to navigate their way through a maze of education and training options, in the process of building unique personal careers for themselves. Periods of conventional employment may alternate with further education or training, free- lance work or self-employment and, perhaps, spells of unemployment. And as life-long learning becomes essential, high-quality educational and career guidance will become equally important. But in many countries the guidance system will have to be rethought so that it can respond rapidly and flexibly. The long-established systems of some countries have become rigid and overly-bureaucratic; in others, large gaps in provision mean that many young people (often those who require it most pressingly) are not getting the service they deserve.

A study carried out recently by the OECD Centre for Educational Research and Innovation examined educational and career guidance in seven OECD countries: Austria, Canada, Finland, Italy, Japan, Mexico and Scotland. 'The aim was to draw out examples of good practice and innovation which might be of use to policy-makers in other countries.

Different countries define such guidance in different ways. The study identified three central elements:

- educational guidance - supervising a young person's academic progress, and such elements as the acquisition of good studying habits, tackling learning difficulties effectively, choosing certain subjects, programmes or pathways, or making decisions as to what type of school to attend

- career guidance - focusing on understanding the world of work, choosing an occupation and 1. Mapping the Future: Young People and Career Guidance, OECD Publications, Paris, forthcoming 1996. 2. Jean-Clande Paye, Strategies for a Leaming Society? The OECD Observer. No. 199, April/May 1996; Edum Letwen and Albert Tuijnman. Life-long Leaming: Who Pays?: The OECD Observer, No. 199, AprillMay 1996. 3. Education at a Glance: OECD Indicators. $O E C D$ Publications, Parts, 1995.

4. OECD reports on the United Kingdom often focus on England and Wales; since the Scottish education system is different, it was decided on this occasion to examine Scolland separately, 


\section{Educational and Career Guidance: What Works}

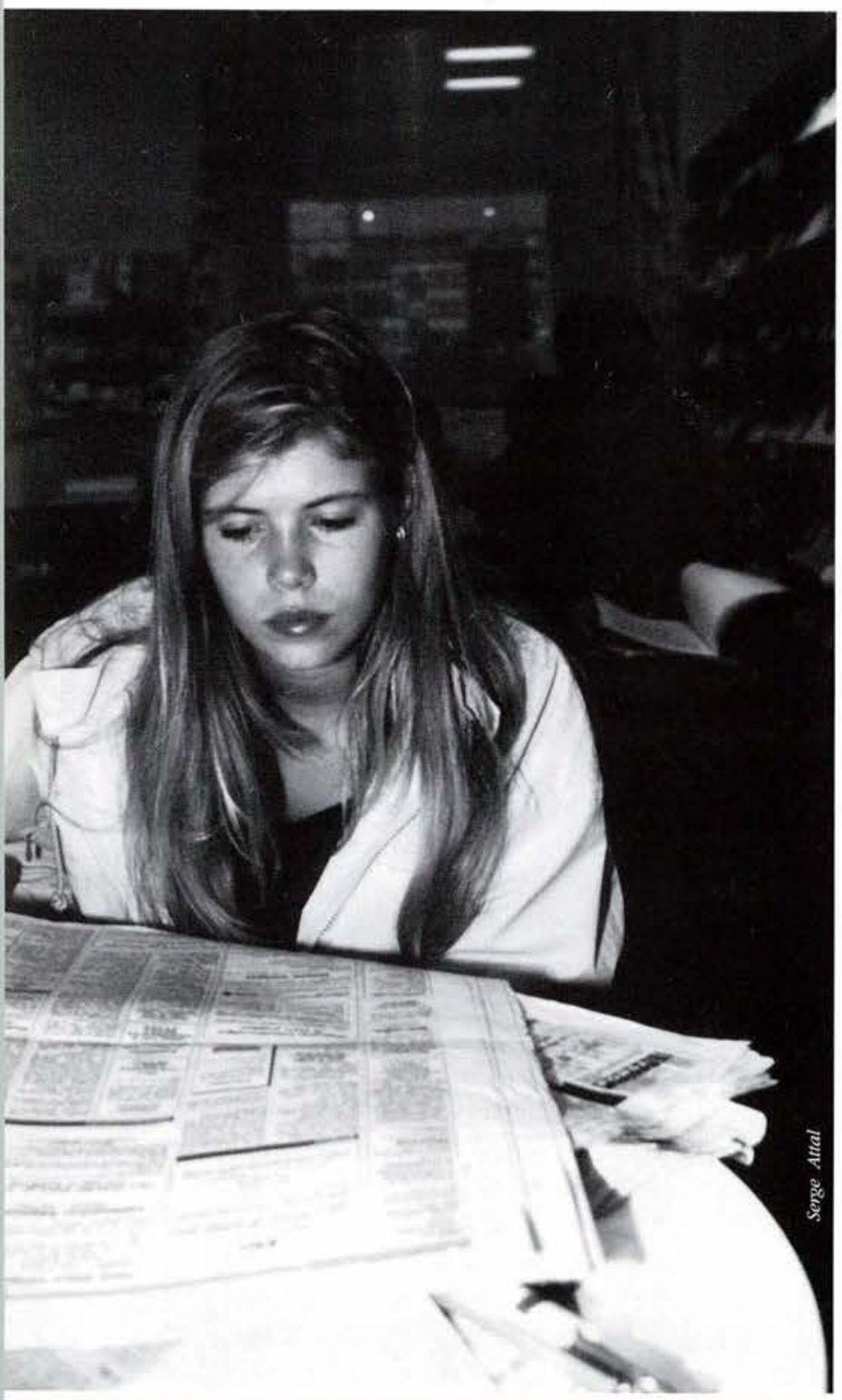

For many young people, finding a path into the labour market is becoming harder.

smoothing the transition from school to employment

- personal and social guidance - encouraging individuals to understand themselves as they change and develop, perhaps involving advice on how to deal with practical or emotional issues such as financial difficulties or family problems.
Schools are not, of course, the only places in which young people receive educational and career guidance. Since in virtually all OECD countries, responsibility is divided - not always neatly - between the Ministry of Education and the Ministry of Labour or Employment, guidance tends to be offered by three different types of institution, each with its characteristic strengths and weaknesses.

- Educational institutions. Their major advantage: teachers and school counsellors know the young people they are advising and educational options available. Their most important weaknesses: teachers may have low expectations and fixed ideas concerning some individuals' abilities or attitudes, they are often unfamiliar with the requirements of the labour market, and they cannot normally advise adults or young people who have already left school.

- Labour-market organisations, which may be government-administered through training or employment centres, or run by employers or trade unions. Main strengths: guidance is available to adults and to young people who have left school, and the advisers are in close contact with the labour market. Main weaknesses: the guidance workers' knowledge of educational and training options is often limited, and too much emphasis on placement in jobs and the interests of employers can mean that not enough attention is paid to the individual's requirements and aptitudes.

- Agencies (whether public, private or voluntary). Advantages: agencies can liaise between educational institutions and employers and can offer guidance to adults and young people who have left the system. Since they are detached from both the schools and colleges (who might be trying to maximise student numbers in their own interests) and employers (who might merely be looking for cheap labour), the clients of public agencies, in particular, may have a better chance of getting unbiased advice. Disadvantage: coverage can be uneven, with gaps and duplication. What's more, the clients of private agencies may not be getting good value for money (they may not realise they are not getting good advice) and the poor may be unable to afford professional help - although they are the ones who could use it best.

This range of different settings gives rise to a range of difficulties - from the sometimes uncertain professional status of the people offering advice to problems of overlap, incoherence and other inefficiencies. But it would probably be a mistake to rationalise the supply of guidance too thoroughly, since it is required by disparate individuals. Indeed, to maximise both coverage and quality, most countries would do well to diversify further the settings in which guidance can be obtained, so as to reach more of the people who are currently excluded from professional advice.

\section{What Countries Do}

Career guidance involves a large number of different activities, including giving information, advice and counselling; assessing individuals interests, attitudes, skills and aptitudes; advice on the choice of career; job-placement; and advocacy (for example, on behalf of those who risk exclusion, or who may experience barriers in their attempts to get access to training or jobs).

The emphasis placed on different activities varies from country to country. The giving of information, for example, is a very basic requirement, where in most countries career- or jobcentres are strong - but schools are sometimes very weak. In Austria, the schools can supplement their own resources by using the Career Information Centres (Berufsinformationszentrum, or BIZ), and in Scotland they call on the Scottish Careers Service. Both services have 
strong information bases - including computerised databases - and a staff accustomed to using new technology. In Mexico City, between May and August when young people have to choose from a wide range of upper secondary schools, they can get information through a telephone hotline set up by the Secretariat of Education, or consult one of 16 mini-offices throughout the city.

Some countries - such as Austria, Finland, Scotland and some of the Canadian provinces have systematically built careers education into the school curriculum; but in others it is more haphazard and may depend on the particular school district, individual school, or even teacher or group of teachers. The degree to which it features in the school curriculum may also depend on the availability of teaching materials.

In Austria, Italy, Japan and Mexico, only the Employment Centres run by the Ministry of Labour are officially entitled to carry out jobplacement (although in Japan, where the choice of organisation is normally more important than choice of occupation, secondary-school teachers do often play a key role in finding the right company for their students). In Canada and Scotland, other guidance agencies, both public and private, can perform this function - and often do.

Some of the most interesting developments are the result of attempts to meet a particular demand. In Japan, for example, students entering one of the few innovative high schools in Tokyo attend a two-day pre-entry session to help them plan their studies, and then go through a ten-day orientation course which includes an element of career guidance.

Often new approaches are developed in order to target young people who cannot be reached by conventional methods. In Italy, the government-sponsored 'Right to Study' initiative ('Diritto allo Studio') enables more disadvantaged students to enter university, and to succeed when

5. A good careers-education programme offers a range of planned experiences (which may include discussions uorksbops on issues sucb as interview techniques or writing resumés, role play, uork experience or work shadouing). These are designed to develop skills concepts and knowledge which will enable young people to make appropriate career choices and successfully enter the uorking world. they get there. Young people in some Canadian schools, colleges and universities have been trained to act as counsellors to their peers. In Scotland, schools in one education authority have set up evening sessions for students who want help with their schoolwork, career advice and, sometimes, confidential counselling. Innovative practices of this type should be much more widely disseminated, and encouraged by policymakers through targeted funding; otherwise, they may remain dependent on the energy and commitment of a few individuals.

Probably the most widespread and successful innovation of the last decade has been the growth of partnerships between schools and local companies, particularly in terms of providing work-experience for secondary school students. The placement usually lasts between three days and three weeks. Sometimes it turns out to be a bridge to a permanent job, but more often placements are used as 'tasters' to give the student some idea of what a particular occupation en- tails, or simply to communicate the experience of going to work.

In many OECD countries this is now a common practice. All secondary-school students in both Scotland and Finland go on work-experience as part of their general education and introduction to adult life. In Canada and Austria. it more often plays a part in the vocational preparation of young people who are not destined for tertiary education. In Italy, on the other hand, it tends to be the high-fliers who are offered work-experience - the result of collaboration between high schools and local industrialists, who can thereby pick the cream of the graduating students.

There are numerous other forms of introduction to the workplace, including:

- work-shadowing, in which students follow workers on a one-to-one basis throughout the day, observing the tasks they carry out, and their roles within the firm

- mentoring, a scheme in which successful

One of the advantages of agencies is that they tend to give unbiased advice.

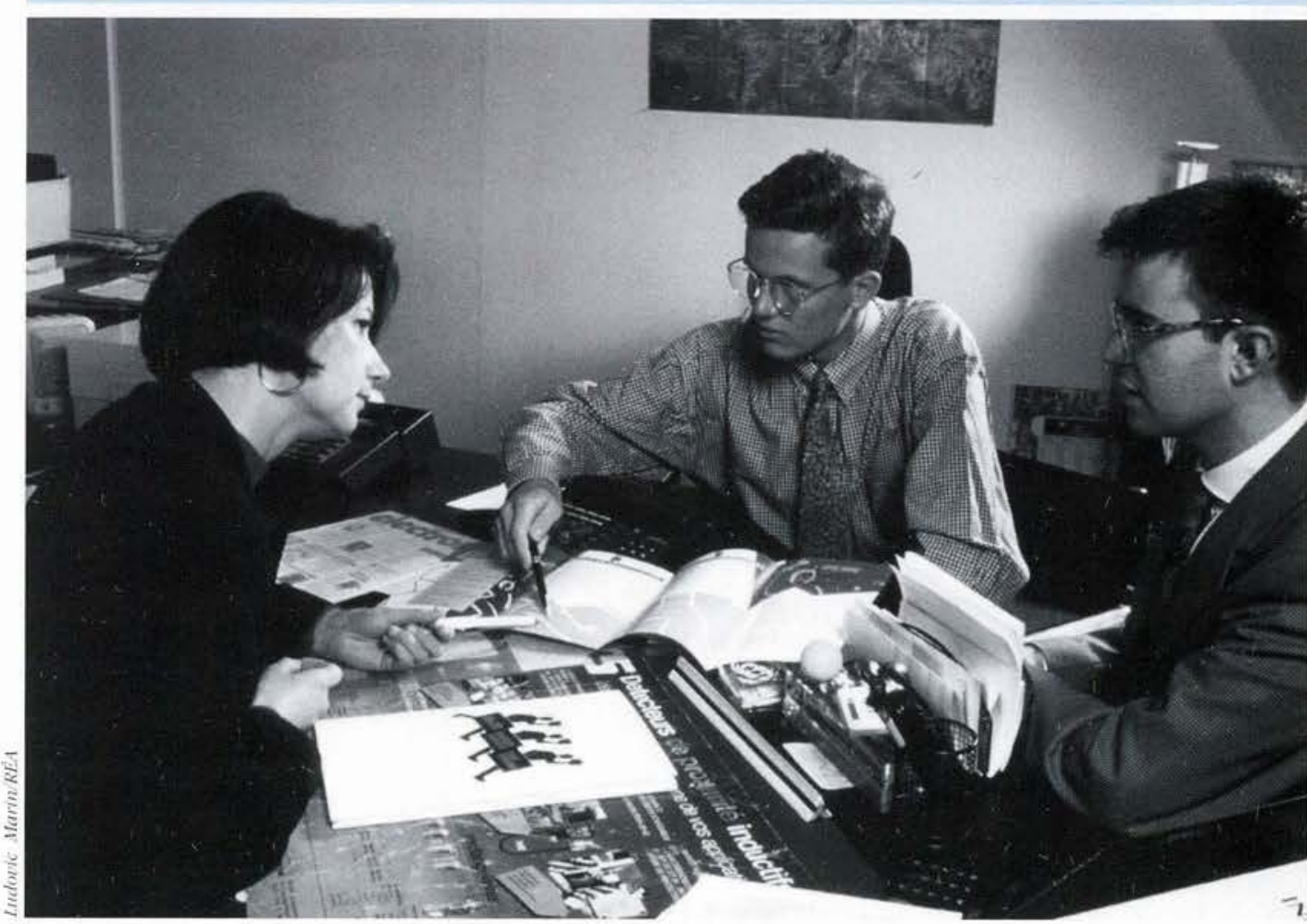




\section{Educational and Career Cuidance: What Works}

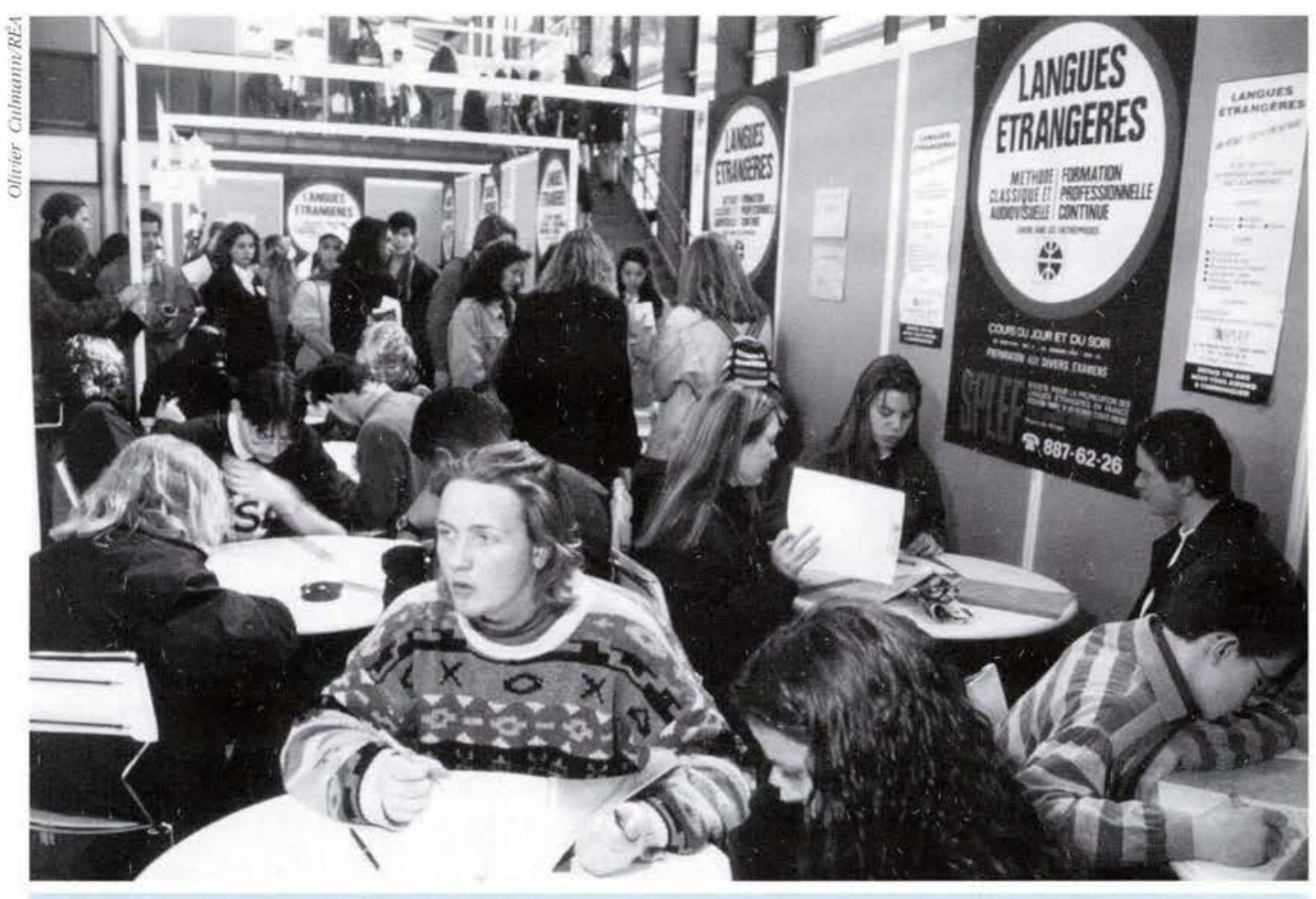

Information is a vital element in making career choices - but obtaining it is not always easy.

ments should set up audits of their own systems, with the aim of recording what is already in place - both within educational institutions and outside - and identifying gaps in provision. In many countries there is a general dearth of good materials on guidance for the use of teachers, counsellors and others. This lack is particularly important when clients are undecided, poorly motivated or are newly arrived in the country.

An effective system should offer educational and career guidance to everyone - from early teens until well into adulthood - as an integral element of their education or training curriculum, rather than restricting it to transition points or to individuals with problems.

Access to information and to guidance is a real problem in many countries, especially for individuals who are no longer in education or training. Innovative methods of delivering information, especially through computer-based technologies, should

members of ethnic minorities offer themselves as role models to young people from the same community; they offer them work experience and work-shadowing, discuss their problems and ambitions, and take an interest in their progress. This technique is also useful in encouraging girls to aim higher or to enter non-traditional occupations.

- simulations, which may involve games, roleplaying and practice of various kinds, usually carried out on school premises but often in realistic surroundings

- work-experience for teachers, a successful innovation in the Austrian province of Styria; the teachers who have taken part in the scheme value not only the information they gain about the working world, but the experience of looking at education from another point of view.

All of these approaches share an important element: breaking-down the barriers between the school and the outside world so that students can make choices on the basis of know- ledge and experience of the workplace - and understand themselves better too. The school of tomorrow will have to have more permeable walls, so that both young people and adults can move freely in and out of it. ${ }^{6}$

If educational and career guidance are to fulfil their potential in easing transitions, improving the workings of the labour market, and helping individuals to get the most out of their lives, they have to adapt to this rapidly changing labour market. Four principal messages emerge from the research.

Although there is much good practice in all the countries in the study, incoherent or incomplete systems tend to be the norm. Large numbers of young people and adults who could benefit from career guidance have to go without, or receive an inadequate service. Govern-

6. Abrar Hasan and Alan Wagner. The School of the Future', The OECD Observer: No. 199. April/May 1996. be developed, and new ways of offering guidance - perhaps in public libraries, shopping centres, or through the use of 'careers hotlines' should be explored.

\section{OECD BIBLIOGRAPHY}

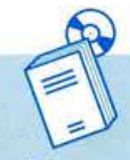

Mapping the Future: Young People and Career Guidance, forthcoming 1996

Making Life-long Learning a Reality for All, 1996 Jean-Claude Paye, 'Strategies for a Leaming Society', The OECD Observer, No. 199, Apri//May 1996 Edwin Leuven and Albert Tuijnman, 'Life-long Leaming: Who Pays?, The OECD Observer, №. 199, April-May 1996

Abrar Hasan and Alan Wagner, The School of the Future', The OECD Observer, No. 199, April/May 1996 Education at a Clance: OECD Indicators, 1995 Schools and Business: A New Partnership, 1992. 


\section{From Competition}

\section{to \\ Growth}

Dirk Pilat

The slowdown of growth in the OECD area over the past decades has led to a re-assessment of regulations and economic institutions. Wide-ranging reforms of financial, labour and goods markets have been implemented in many countries. In product markets, reforms to strengthen competition have aimed at lowering prices, enhancing productivity and stimulating output and employment. But how precisely does competition affect economic performance? And what gains can be expected from fiercer competition?

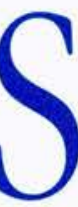

ince the mid-1970s, output and productivity growth have been disappointing throughout the OECD area, and unemployment has risen steadily in many countries. One of the responses of OECD governments over the past fifteen years was the implementation of programmes of structural reform to tackle the rigidities in labour, financial and goods markets that had introduced substantial distortions in the functioning of the economy and contributed to unsatisfactory performance. Although varying in scale and scope, reform has been wide-ranging, with the liberalisation of financial and international product markets leading the way in most countries and reforms of domestic product markets, particularly services, and labour markets trailing behind.

Distortions in product markets - resulting, for instance, from entry regulations, trade barriers or government subsidies - can affect economic performance in several ways. For instance, a low degree of competition may lead to 'monopoly

Dirk Pilat works in the Resource Allocation Division of the OECD Economics Department. pricing, with firms setting their prices above those prevailing under competitive conditions, leading to economic 'rents'. A 'rent', of course, can reward entrepreneurship and thus encourage innovation (in, for example, medicines and computers), but this reward should not last forever - competition should be free to erode it before too long. Otherwise, firms can make 'excess' profits, which they can spend in different ways - by paying workers excessive wages, which can contribute to unemployment, by tolerating overstaffing, which tends to be unsustainable in the long run, or by allowing technical inefficiency to build up.

\section{Competition and Prices}

The most direct effect of insufficient competition is on prices. In the theoretical situation of perfect competition, firms are pure 'price-takers': they have no influence on price-setting because competitive pressure forces them to accept what the market permits. With healthy competition firms set their price according to marginal costs, implying that they expand production until the cost of the last unit sold equals the market price. Imperfections in product markets allow them to charge a mark-up over their marginal costs, pushing up prices and lowering output. In practice, of course, there are always market imperfections which allow prices to deviate from marginal costs. The swiftness with which markets can move to eliminate these imperfections - attracted by the monopoly rents they produce - can indicate the relative efficiency of an industry or, indeed, of an economy as a whole.

It is difficult to assess how much firms charge as a mark-up over their marginal costs, since they are not directly observable. But the extent to which prices fall following a strengthening of competition can give some indication of the size of the rent. For instance, prices in road freight transport have fallen in most OECD countries following a strengthening of competition, and the prices of telecommunication services have likewise fallen faster in countries with competitive markets, indicating that rents were initially present in these industries. ${ }^{2}$ Recent analysis by the $\mathrm{OECD},{ }^{3}$ moreover, based on an assessment of mark-ups in 36 manufacturing industries in 14 member countries, suggests the existence of sizable mark-ups in many of them (Table 1), mostly ranging between 10 and 30\%, although some industries have mark-ups over $40 \%$. In principle, these figures suggest a substantial deviation from competitive conditions.

As well as indicating weak competition or returns to innovation, large mark-ups can also signal high sunk costs that are inherent to the production technology of a particular industry such as iron and steel - since these costs have

1. Dirk Pilat, Competition. Productivity and Effictency OECD Economic Studies. No. 27, OECD Publications, Paris, fortbcoming 1996.

2. Jens Hoj, Tosbiyasu Kato and Dirk Pilat, Deregulation and Privatisation in the Service Sector, OECD Economic Studies No. 25, OECD Publications, Paris, 1995; Sam Paltridge, How Competition Helps the Internet The OECD Observer, No. 201. August/September 1996.

3. Joaquim Oliveira Martins, Stefano Scarpetta and Dirk Pilat, Mark-up Ratios for Manufacturing Industries: Estimates for 14 OECD Countries: OECD Economics Department Working Papers, No. 162, atailable free of change from the Resource Allocation Division of the OECD Economics Department. 


\section{From Competition to Crowth}

\begin{tabular}{|c|c|c|c|c|c|c|c|}
\hline & United States & Japan & Germany & France & Itoly & United Kingdom & Canada \\
\hline Food products & 1.07 & 1.35 & 1.10 & 1.10 & .. & 1.19 & 1.10 \\
\hline Textiles & 1.09 & 1.17 & 1.13 & 1.10 & 1.18 & 1.03 & 1.23 \\
\hline Paper products & 1.12 & 1.23 & 1.23 & 1.11 & 1.15 & 1.04 & 1.37 \\
\hline Industrial chemicals & 1.22 & 1.27 & 1.40 & 1.21 & 1.17 & 1.05 & 1.50 \\
\hline Drugs \& medicines & 1.45 & 1.75 & 1.49 & .. & .. & 1.11 & 1.27 \\
\hline Iron \& steel & 1.10 & 1.43 & 1.18 & 1.11 & 1.14 & $\ldots$ & 1.26 \\
\hline Metal products & 1.10 & 1.12 & 1.20 & 1.17 & 1.42 & 1.03 & 1.14 \\
\hline $\begin{array}{l}\text { Office \& } \\
\text { computing machinery }\end{array}$ & 1.39 & 1.32 & & 1.18 & 1.65 & 1.43 & 1.14 \\
\hline $\begin{array}{l}\text { Radio, TV \& communic } \\
\text { equipment }\end{array}$ & 1.38 & 1.15 & 1.28 & 1.11 & 1.19 & 1.28 & .. \\
\hline Motor vehicles & 1.06 & 1.18 & 1.13 & 1.13 & 1.02 & & 1.14 \\
\hline $\begin{array}{l}\text { not available } \\
\text { 1. The ratio of price and } \\
\text { Source: } O E C D\end{array}$ & ted) marginal & & & & & 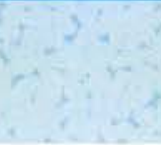 & \\
\hline
\end{tabular}

little influence on pricing decisions. But if high mark-ups derive from a lack of competition, prices are higher than necessary and consumers and other industries pay more than they ought to for the products from a particular sector. That may impose substantial costs on society as a whole.

Analysis by the OECD suggests that some of the variation in mark-ups can indeed be attributed to a lack of competition. Trade barriers and low rates of entry by new competitors, for

\footnotetext{
4. The OECDJobs Study: Evidence and Explanations. OECD Publications, Paris, 1994; and Paul Geroski. Paul Gregg and John wan Reenen. Market Imperfections and Employment, OECD Economic Studies. No. 26. OECD Publications, Paris, forthcoming 1996.

5. The most extensiue study of this type is by $A$. B. Krueger and $L . H$. Summers. Efficiency Wages and the InterIndustny Wage Structure: Econometrica, Vol. 56, 1988 see also The OECD Jobs Study: Evidence and Explanations.

6. The OECD Jobs Study: Evidence and Explanations discusses wage flexibility and the role of wage-premia in more detail.

7. Assessing Structural Reform: Lessons for the Future OECD Publications, Paris, 1994.

8. A. Steven Englander and Andrew Gumey, Productivit] in Perspective, The OECD Observer, No. 188, June lity 1994

9. See pp. 17-21
}

instance, appear to be associated with high markups. Mark-ups also tend to be higher in service industries than in manufacturing, which is consistent with the view that most services are often less exposed to strong competition that manufacturing sectors - partly because services, with some exceptions, are not subject to much international competition; service sectors also tend to be more heavily regulated than manufacturing.

\section{Do Workers Share the Rents?}

If a firm earns excessive rents (that is, high mark-ups) in the goods market, it may decide (or be forced through union pressure) to share them with its workers in the form of higher wages - 'wage-premia'. The evidence that wagepremia exist is fairly strong. Several empirical studies have found that wages differ systematically across sectors, even when account is taken of differences in worker characteristics, such as age, education, occupation and gender.' Manufacturing, transport, utilities and financial services often pay relatively high wage-premia, whereas agriculture and the distribution sector have among the lowest wage-premia.

The existence and persistence of large differentials in wages between industries calls into question the competitive nature of the labour market, as wages would tend to be harmonised under competitive conditions. In addition, wages that differ substantially across sectors for workers in similar occupations may provide an incentive to 'queue' for jobs in high-wage sectors. And, indeed, that does appear to occur in several OECD countries. Most studies also find that wagepremia are relatively stable over time, indicating that they are derived not so much from temporary disequilibria or windfall profits as from rigidities in the labour market.

The share of wage-premia in total labour compensation (that is, wages and other monetary benefits) appears to be particularly high in Canada and the United States and is of less importance in Europe or Japan. The high wagepremia in the United States and Canada can be ascribed to the decentralised nature of wagebargaining in these countries, which gives workers more opportunity to appropriate rents of individual firms. There is some evidence that wage-premia are higher in sectors with a low degree of competition, such as public utilities, suggesting that they are at least partly the result of rent-sharing behaviour. Furthermore, the observable fact that they tend to fall if a sector is deregulated points to a direct link between the relative competitiveness of a product market and the behaviour of wages.

If wage-premia in a particular sector are derived from rent-sharing, labour costs in that sector will usually be higher than healthy competition would have permitted and the demand for labour will be concomitantly lower. That does not necessarily mean that employment as a whole will be lower: if other sectors are sufficiently flexible to offset the loss of employment caused by wage-premia, economy-wide employment may not be affected.

This is particularly likely to be the case in economies with decentralised wage-bargaining and flexible labour-market arrangements, such as the United States. But if wage-premia are accompanied by centralised wage-bargaining or 
the extension of wage-agreements for individual firms to a whole sector, or if other institutional arrangements in the labour market, such as strict employment-protection legislation or inefficient tax-benefit systems, reduce flexibility, they may well contribute to unemployment. As a result, even though wage-premia in the United States are higher than in Europe, their consequences for employment may very well be higher in Europe than in the United States, since in Europe they add to many other sources of inflexibility in the labour market.

\section{Productivity and Efficiency}

In principle, a well-functioning market economy allocates scarce resources more efficiently than any alternative system. But imperfections in goods or factor markets, such as entry regulations, government subsidies or trade barriers, can introduce inefficiency and reduce long-term growth. Weak competition may, for instance, result in resources being tied to activities with low productivity. For instance, many nationalised industries in the United Kingdom during the 1970 s were characterised by overstaffing, leading to extremely poor productivity and high costs. There is a second, potentially even more important, effect. Low competition reduces the pressure on firms to incorporate new technology or innovate, resulting in low growth of productivity and a loss of competitiveness. ${ }^{8}$

Cross-country comparisons of the productivity of labour, both in manufacturing and services, suggest substantial differences between OECD countries (Table 2). Within manufacturing, the United States remains the world leader in labourproductivity although some countries, such as Japan, the Netherlands and Sweden, have surpassed US productivity in individual industries. For instance, Japan is the productivity leader in iron and steel and shipbuilding, the Netherlands in textiles and industrial chemicals, and Sweden in paper products.

Variations in productivity partly reflect differences in the abundance of production factors in different countries and the resulting costs of labour, capital and material inputs. Firms in countries such as Mexico, Portugal and Spain, for instance, face lower labour-costs than firms in higher-income economies and consequently choose relatively labour-intensive production technologies, leading to low productivity. But there is increasing evidence that inefficient practices, including the organisation of functions and tasks within a firm," also play a role in explaining low productivity.

In manufacturing industries international competition, either through trade or foreign direct investment (FDI), is an important element in improving efficiency, and the highest degrees of productivity tend to be achieved by companies competing directly with best-practice firms across the globe. Moreover, the diffusion of technology across countries appears to be slower in indus- tries where competition is weak, as openness to competition allows firms to learn from their international competitors. In service industries, domestic regulations are often an important restriction on competition. For instance, regulations on entry to the airline market in many European countries have reduced competition and contributed to high prices, whereas restrictions on large-scale establishments in Japan and a number of European countries have reduced the free play of competition in the distribution sector.

Open borders and favourable entry conditions for new firms appear to improve productivity growth. Furthermore, the wide variation in productivity across the OECD area, both in manufacturing and services, suggests substantial scope for further improvements. Firms trying to catch

\begin{tabular}{|c|c|c|c|c|c|}
\hline & $\begin{array}{l}\text { Manufacturing } \\
\text { (value added } \\
\text { per hour') }\end{array}$ & $\begin{array}{l}\text { Retail trode } \\
\text { (retail sales } \\
\text { per employee') }\end{array}$ & $\begin{array}{l}\text { Construction } \\
\text { (value added } \\
\text { per employee') }\end{array}$ & $\begin{array}{l}\text { Electricity } \\
\text { (gigawatthour } \\
\text { per employee) }\end{array}$ & $\begin{array}{c}\text { Telecommunications } \\
\text { (revenue } \\
\text { per employee') }\end{array}$ \\
\hline United States & 100.0 & 100.0 & 100.0 & 8.18 & 100.0 \\
\hline Japan & 76.2 & 70.7 & 79.7 & 6.34 & 80.6 \\
\hline Germany & 85.0 & 100.7 & 75.5 & 2.20 & 63.1 \\
\hline France & 90.5 & 94.8 & 83.3 & 3.83 & 68.3 \\
\hline Italy & .. & 72.3 & 84.2 & 1.63 & 89.3 \\
\hline United Kingdom & 70.1 & 77.6 & 62.0 & 2.18 & 68.9 \\
\hline Canada & 77.2 & .. & 148.2 & 5.46 & 73.9 \\
\hline Australia & 52.0 & 60.1 & 103.0 & 2.92 & 70.6 \\
\hline Belgium & & 94.1 & 90.1 & 3.15 & 58.6 \\
\hline Denmark & & 68.6 & 65.8 & 3.31 & 53.4 \\
\hline Finland & 85.0 & 85.9 & 94.4 & 3.06 & 48.0 \\
\hline Netherlands & 108.8 & 54.8 & 69.9 & 3.08 & 88.0 \\
\hline New Zealand & & 85.8 & & 3.39 & 65.2 \\
\hline Spain & 67.6 & 45.7 & 86.8 & 3.28 & 74.2 \\
\hline Sweden & 92.0 & 86.9 & 75.2 & 5.60 & 50.4 \\
\hline $\begin{array}{l}\text {.. not available } \\
\text { 1. } 1994 \text {. } \\
\text { 2. } 1990 \text {. } \\
\text { 3. } 1993 . \\
\text { 4. } 1992 \text {. }\end{array}$ & 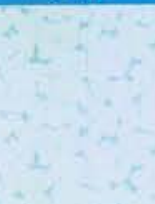 & & & & $25+5$ \\
\hline
\end{tabular}




\section{From Competition to Crowth}

up with best-practice competitors play an considerable role here, once again indicating the importance of technological 'learning'. The fact that productivity leadership within manufacturing is shared among several countries, with individual countries being the leader in different industries, implies that there is a potential for further catch-up in all countries, not only those with low productivity.

\section{Good Policies, Bad Policies}

Product markets in OECD countries show many signs of rigidity. Prices in many sectors are higher than they ought to be, wage-premia are enjoyed in many sectors, and low productivity and inefficiency are widespread. And the evidence often points to specific barriers to competition, indicating the desirability of a change in policy. For instance, a high degree of concentration of firms appears to increase both markups and wage-premia, whereas openness to international trade brings them down and improves productivity growth.

There are a number of ways in which governments can stimulate competition in goods markets. Trade and FDI can promote competition from abroad. ${ }^{10}$ Trade barriers have fallen substantially over the past decades, although further progress remains to be made, particularly in services and FDI.

Governments can also continue regulatory reform. Many sectors of the economy, especially services, are subject to direct and indirect controls on prices, on entry and on the activities permitted. But new market realities have necessitated the sweeping-away of aging regulation. Changing technology, in telecommunications for instance, has encouraged a re-evaluation of regulatory practice, the result generally being falling prices and the increased entry of new firms."

Competition policy is also being overhauled. Much progress has been made here over the past years, with many $\mathrm{OECD}$ countries strength-

10. See pp. 6-9

11. Sam Paltridge, Upuardly Mobile Telephony: Tbe OECD Observer, No. 196, Octoben/November 1995. ening competition legislation and enforcement practices. Partly driven by EU legislation, many European countries have introduced new competition laws in recent years, often driven by the 'prohibition' principle, under which restrictive business practices are explicitly forbidden. This attitude contrasts with a much more lenient stance than in the past, where anti-competitive conduct was often tolerated as long as no harmful effects were visible or no complaints to competition authorities were made.

Only a few countries, including New Zealand, the United Kingdom and the United States, have implemented extensive programmes of structural reform in product markets. Most others have opted for a gradual approach, tackling individual sectors one at a time. Road transport, distribution, telecommunications and airlines have all benefited from stronger competition, with prices falling in most countries, and increased entry of new firms. The economy as a whole has likewise emerged better-off. Estimates of the economy-wide effects range from a possible increase in annual GDP by $0.6-0.8 \%$ for the United States to $1.5 \%$ for the European Union and an even higher (projected) $5.5 \%$ for Australia.

The increased globalisation of economies will require more flexibility and adaptability. Stronger competition in product markets can help by improving the allocation of resources and enhancing economic growth, reducing prices and wage-premia, stimulating productivity and innovation - and would lead to higher incomes and real wages in the long run. In the short run, the consequences of enhanced competition for employment are ambiguous. If a firm or industry is highly inefficient, it could well have to shed jobs as it adapted to the changed conditions. But before too long improved efficiency should stimulate growth and therefore employment. In some sectors, furthermore, such as telecommunications, enhanced competition also appears to have resulted in a higher degree of innovation and an expansion of output and employment. Lower wage-premia could improve the flexibility of the labour market and thus expand employment.
Intensified competition may thus entail transition costs, in the form of higher unemployment in the short run, in particular if accompanied by large-scale rationalisation and improvements in efficiency. These transition costs are likely to be highest in sectors and countries where the potential for efficiency gains is largest, particularly in countries with inflexible labour markets - the comprehensive programmes of structural reforms in the United Kingdom and New Zealand over the past decade show that the adjustment process may indeed be slow and painful if labour markets are inflexible. And there is obviously some complementarity in reforms in both markets. If reforms in product markets lead to higher growth of output, it could enhance the scope for reform of labour markets. 


\section{Germany \\ The Welfare System}

\section{Eckhard Wurzel}

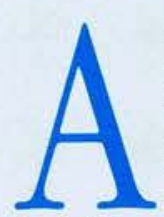

high burden of taxation and an increasing number of recipients wholly or partly dependent on public transfers have brought the welfare system in Germany into question. Social benefits, including some paid by employers, amounted to a third of GDP in 1994. Since reunification, this share has increased by more than $3^{1 / 2}$ percentage points. Nearly all programmes have expanded, unemployment benefits and old-age pensions in particular. In 1993 , public social transfers to the new Länder totalled $2.6 \%$ of GDP, nearly two-thirds of which were spent on labour-market measures such as unemployment benefits, early-retirement payments and work-creation projects. Such transfers have underpinned the rapid growth of wages at rates far above the growth of productivity.

The federal nature of the constitution with its emphasis on 'subsidiarity' has created a complex institutional structure, which also involves employers and employees. Following the principle that the local authorities are responsible for government functions that can best be executed locally, it is they who administer and finance social assistance. The principle of subsidiarity is in turn supported by sharing the revenues of certain taxes between different tiers of government, supplemented by a system of transfers between the territorial authorities that aims at securing a high degree of regional equality. Unemployment benefits are administered by the Federal Labour Office, which is supervised by employers and employees and by representatives of all three layers of government. Similarly, the public health funds and the pension funds are administered by employers and employees. the rationale being that social-security contributions are divided equally between them.
There are two types of unemployment compensation, both of which aim at securing a dignified standard of living for the unemployed and at facilitating the search for a suitable job: unemployment benefit, financed by the unemployment insurance system, and unemployment assistance, financed out of general tax revenues and available at a reduced rate after eligibility for unemployment benefit has been exhausted. In both schemes benefits are related to past earnings. Job-creation and retraining measures have a similar welfare effect. A major criticism of the system is that the unemployed have considerable scope to reject job offers without benefits being withdrawn - a degree of liberty which may discourage re-entry into employment, especially for unskilled industrial workers.

\section{How Generous?}

Measuring the generosity of the welfare system is difficult since the question may be approached from several perspectives. One method used by the OECD focuses on income replacement for the unemployed. Hypothetical calculations of net replacement-rates - which relate net income received when unemployed to a measure of potential net income when in employment - indicate that the German welfare system produces a figure for single-earner households of around $70 \%$, based on the earnings of an 'average production worker'. Similar empirical investigations based on household samples show income replacements of a similar magnitude or higher.

Individuals with insufficient resources to achieve a predefined 'social-subsistence' income or to cope with special circumstances (exceptional health-care requirements, reintegration of handicapped persons) have a legal claim on social assistance, whether they work or not, and for an indefinite period. Social assistance increased from around $1 / 2 \%$ of GDP in 1970 to $1 \frac{1}{2} \%$ in 1994 . Underlying the growth of income assistance has been a five-fold increase in the number of recipients, although during the $1970 \mathrm{~s}$ average benefits also increased strongly. Benefits are means-tested against income and wealth, and the withdrawal of income-assistance as income increases results in high marginal rates of implicit taxation of $90-100 \%$. Such rates risk trapping people in unemployment.

Besides these income-replacement schemes there is a tight net of social transfers that are linked to household circumstances. For sickness, employers are obliged to pay wages for six weeks and after that the health-insurance system pays replacement wages for up to 78 weeks. Sickness benefits paid by the employers constitute a substantial additional cost for labour, in part because they are based on all regular earnings over the preceding three months, including overtime and additional wages, and the incentives to abuse the system are considerable. The public healthinsurance system covers nearly all costs of medical care and services, subject to relatively low co-payments by patients.

Several reforms have aimed at containing costs in the health-care system. Outlays have nevertheless been under strong upward pressure, and further attempts to control costs are being made. In view of the increasing financial burden posed by the elderly, a long-term care insurance was added to the transfer system in 1995. This new pillar is controversial since there is a danger that the system could be abused and will prove expensive in the longer run. ${ }^{2}$ In the past much long-term care for the elderly was financed or provided by the families concerned, but the provision of benefits in the new system reduces personal incentives to save in order to meet expenses for required care and weakens incentives to economise.

The provision of retirement pensions in Germany is dominated by the public system,

\footnotetext{
1. OFCD Economic Surveys: Germany. OECD Publications. Paris, 1996.

2. Patrick Hennessy, Paying for Care for the Elderly'. The OECD Observer. No. 201. August/September 1996.
} 


\section{Cermany \\ The Welfare System}

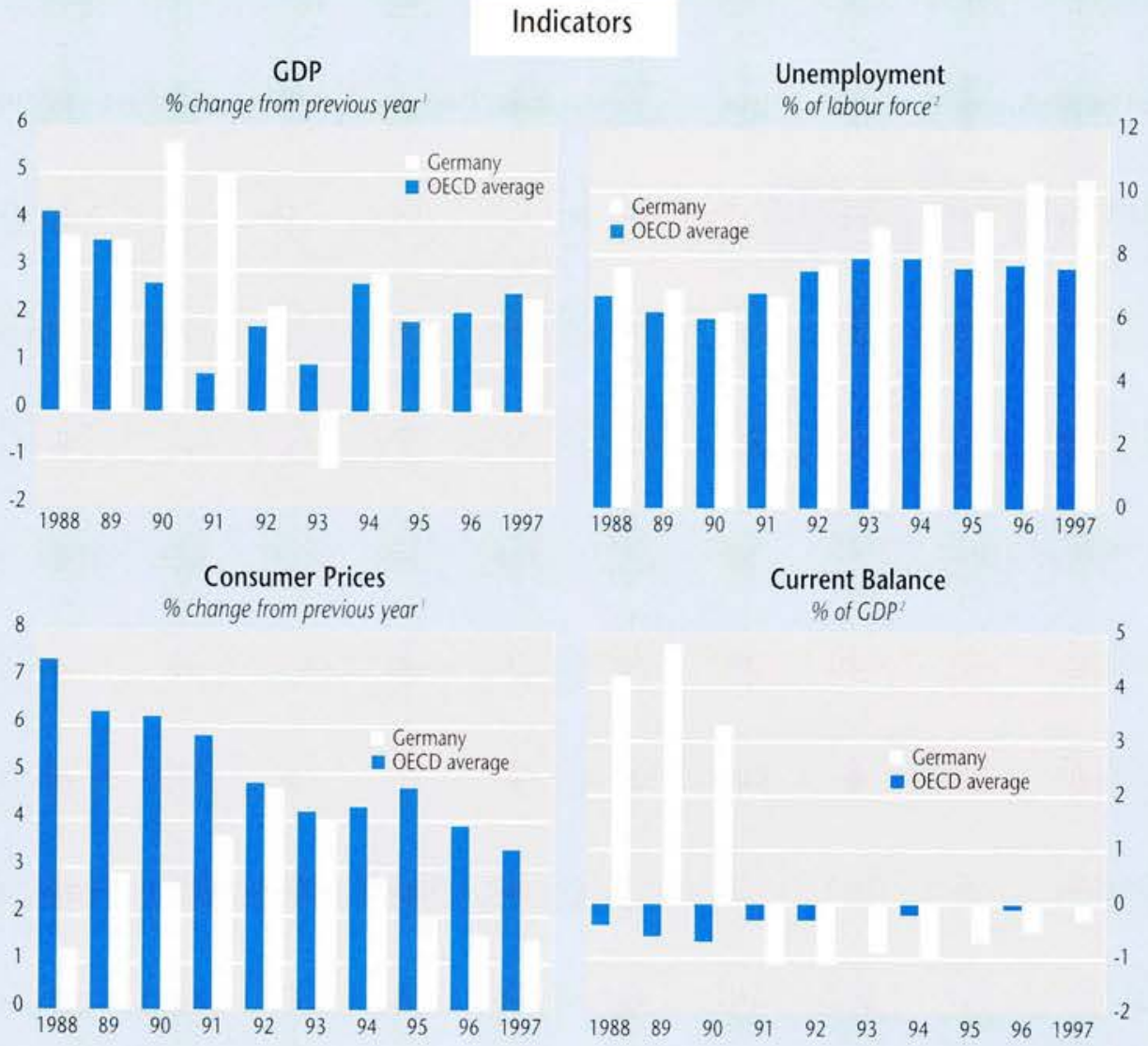

1. Unified Germany from 1992.

2. Unified Germany from 1991

Source: $O E C D$

which provides around $85 \%$ of pensions. In contrast to the other major economies in the OECD where pensions are adjusted in line with movements in prices, in Germany they are indexed to net wages. Since reunification, pensions in the new states have risen by $127 \%$. Increases were most pronounced for women whose average pension is now about $25 \%$ above the figure in the west. Although the standard legal retirement age is currently 65 vears, more than half of the eligible population retires earlier. This tendency has placed a severe burden on the system: early retirement on account of unemployment rose by more than 130\% between 1992 and 1995 in western Germany and by some $600 \%$ between 1993 and 1995 in eastern Germany. Inflow into early retirement is currently being curbed, but it is apparent from Germany's demographic developments that further reforms are required to secure the financial solidity of the pension system. Although the elderly dependency ratio, relating the number of persons aged 65 and older to the number of persons aged between 15 and
64 , is currently about $22 \%$, it is projected to increase to about $55 \%$ in 2035 .

Child maintenance has been given a high priority and, as elsewhere, has led to a marked increase in the complexity of the taxation of personal income. Support for families with children is provided for through child tax allowances as well as a system of cash benefits. Married couples can pool their income, thereby reducing household taxation.

In response to a ruling of the Constitutional Court on the taxation of income, in 1996 the tax-free zone for low incomes has been lifted substantially while initial marginal tax rates have been increased. A striking feature of the German income-tax system is its progressivity: $5 \%$ of taxpayers pay around $37 \%$ of the revenue received from income tax. Tax-rates are also high by international comparison and are reinforced by socialsecurity contribution rates, which increased from $32.4 \%$ of gross wages (paid up to an income ceiling) in 1980 to $40.9 \%$ in 1996 . The tax wedge - the difference between employment costs and wages received, which may discourage employers from taking on staff - is the highest among the major seven economies, and may adversely affect the volume of employment.

\section{What Scope for Reform?}

The German tax/transfer system has generously supported household incomes of the population through a mixture of work-related and other transfers. Support has largely been directed to the younger and older ends of the population distribution and has been financed through high social-insurance contributions from the emploved and an income-tax system which is highly progressive. As such, the system has elements of both vertical redistribution and redistribution over the life-cycle. The welfare system has contributed to the elimination, for all practical purposes, of absolute poverty and a comparatively equitable distribution of income. It has proven flexible enough to adapt to evolving social conditions and to changing demands. Foremost among the latter has been the integration of the new Länder, where wide sections of the population had to be supported during the transition. Moreover the system has undoubtedly contributed good industrial relations, both directly by supporting living standards for those out of work, and indirectly through the decentralised structure which has served to integrate numerous groups into administration and policy-making.

Yet the welfare system has become increasingly removed from the principles which initially underlay the concept of a social market economy: promoting the efficiency and growth potential of the economy has become less and less a guidance to the development of the system. Several potential flaws stand out in this respect.

Net replacement-ratios are often very high, increasing the risk that people will not search actively for jobs and underpinning high wages by raising the reservation wage. The rigid relationship of unemplovment benefits and

Continued on p. 54

3. Willi Leibfritz and Deborah Roseveare, Aging Populations and Government Budgets The OECD Observer. No. 197. December 1995 January 1996. 


\section{Traticators}

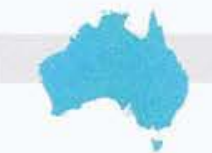

\section{Australia}

period

\begin{tabular}{|c|c|c|c|}
\hline \multicolumn{2}{|c|}{$\sqrt{3} \sin x$} & perioa & year \\
\hline Gross Domestic Produc & Q196 & 1.9 & 4.0 \\
\hline Leading Indicator & Jun. 96 & -0.2 & 0.4 \\
\hline Consumer Price Index & Q296 & 0.7 & 3.1 \\
\hline & & $\begin{array}{l}\text { current } \\
\text { period }\end{array}$ & $\begin{array}{l}\text { same period } \\
\text { last year }\end{array}$ \\
\hline Current Balance & Mar: 96 & -1.17 & -1.91 \\
\hline Unemployment Rate & Apr. 96 & 8.8 & 8.4 \\
\hline Interest Rate & Jun. 96 & 7.60 & 7.55 \\
\hline
\end{tabular}

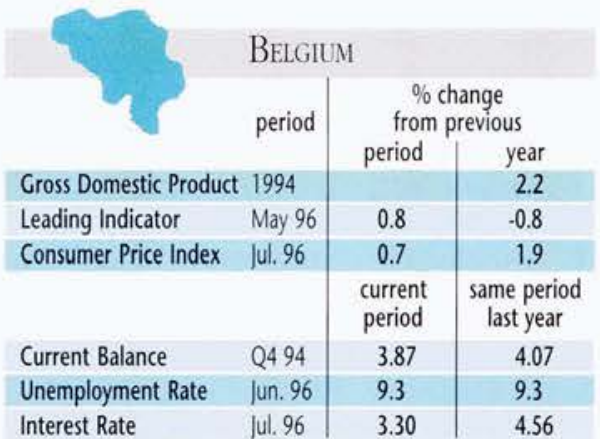

\begin{tabular}{l|l|l|l} 
Interest Rate & Jul. 96 & 3.30 & 4.56
\end{tabular}
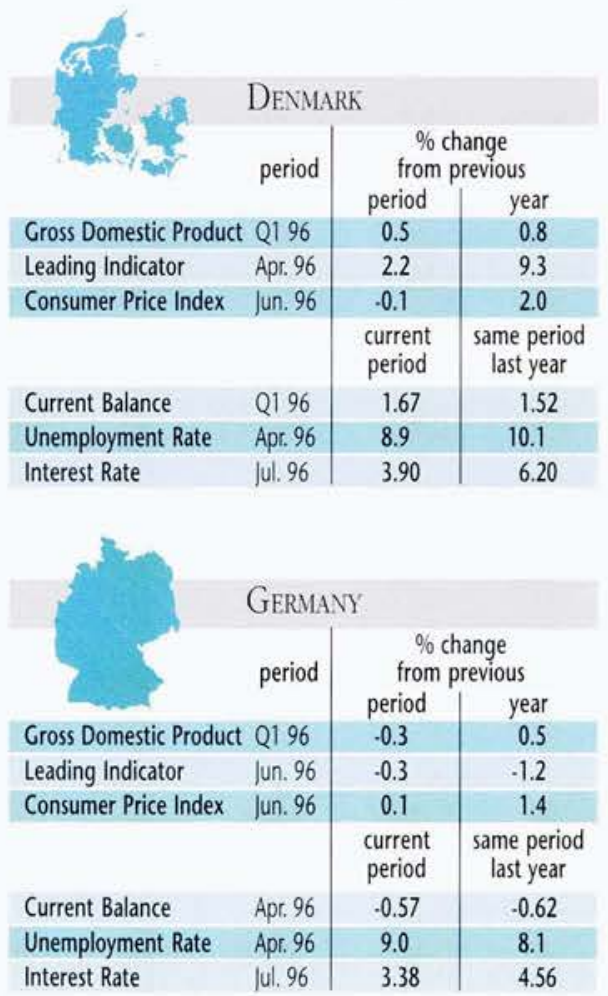

Definitions and Notes

Gross Domestic Product

Leading Indicator

Voliusted except for

Czech Republic and Portuga

A composite indicator,

based on other indicotors

of economic activity

(employment, sales, income,

etc.), which signals cydical

movements in industrial

production from six to nine months in advance

Consumer Price Index Measures changes in average retail prices of a fixed basket of goods and services

S billion; not seasonally adjusted except for

Australia, the United

Kingdom and the United

States

Unemployment Rate \% of total labour force -

110 standardised

unemployment rate;

national definitions for

Austria, Czech Republic,

Denmark, Iceland, Mexico,

Switzerland and Turkey;

seasonally adjusted apart

from Turkey

Interest Rate Three months, except for

Creece (twelve months)

not available

Source: Main Economic Indicators, OECD Publications, Paris, August 1996. \begin{tabular}{ll|l|l|}
\hline Unemployment Rate & Jun. 96 & 7.1 & 6.6 \\
\hline Interest Rate & Jul. 96 & 3.48 & 4.55
\end{tabular}

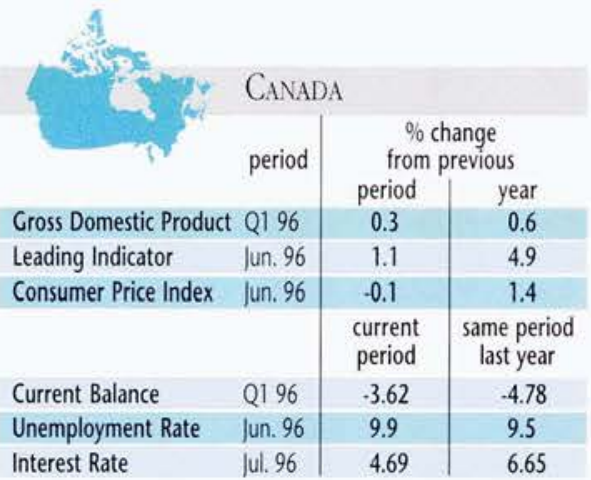

Interest Rate

Jul. 96
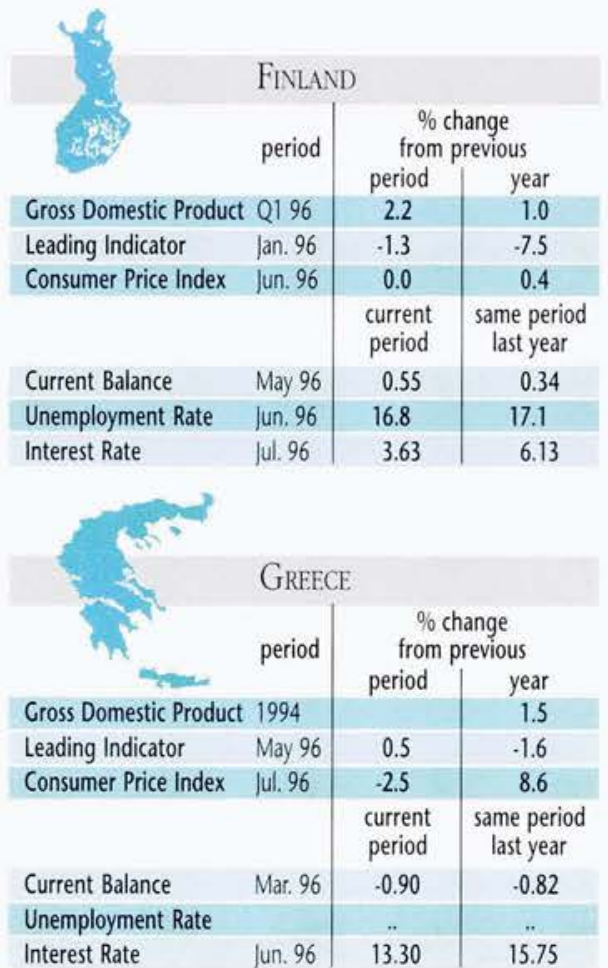

\begin{tabular}{|c|c|c|c|}
\hline \multicolumn{4}{|c|}{ Czech Repubuc } \\
\hline & \multirow[t]{2}{*}{ period } & \multicolumn{2}{|c|}{$\begin{array}{l}\% \text { change } \\
\text { from previous }\end{array}$} \\
\hline & & period & year \\
\hline Gross Domestic Product & Q196 & -2.8 & 4.4 \\
\hline Leading Indicator & & . & .. \\
\hline \multirow[t]{2}{*}{ Consumer Price Index } & Jun. 96 & 0.7 & 8.3 \\
\hline & & $\begin{array}{l}\text { current } \\
\text { period }\end{array}$ & $\begin{array}{l}\text { same period } \\
\text { last year }\end{array}$ \\
\hline Current Balance & Q196 & .0 .54 & -0.22 \\
\hline Unemployment Rate & Jun. 96 & 3.0 & 3.1 \\
\hline Interest Rate & Jul. 96 & 12.80 & 11.64 \\
\hline
\end{tabular}

Interest Rate
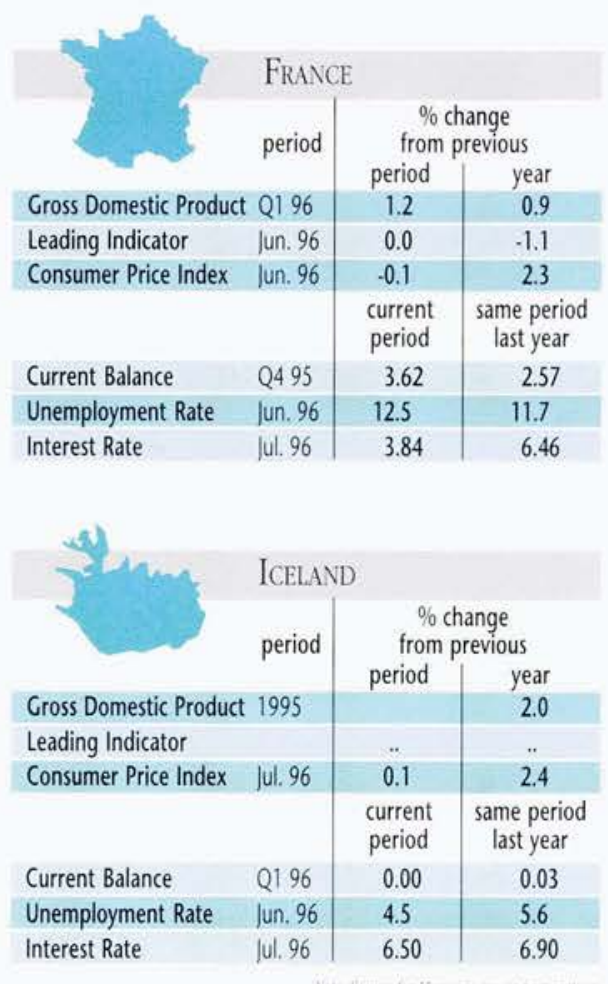

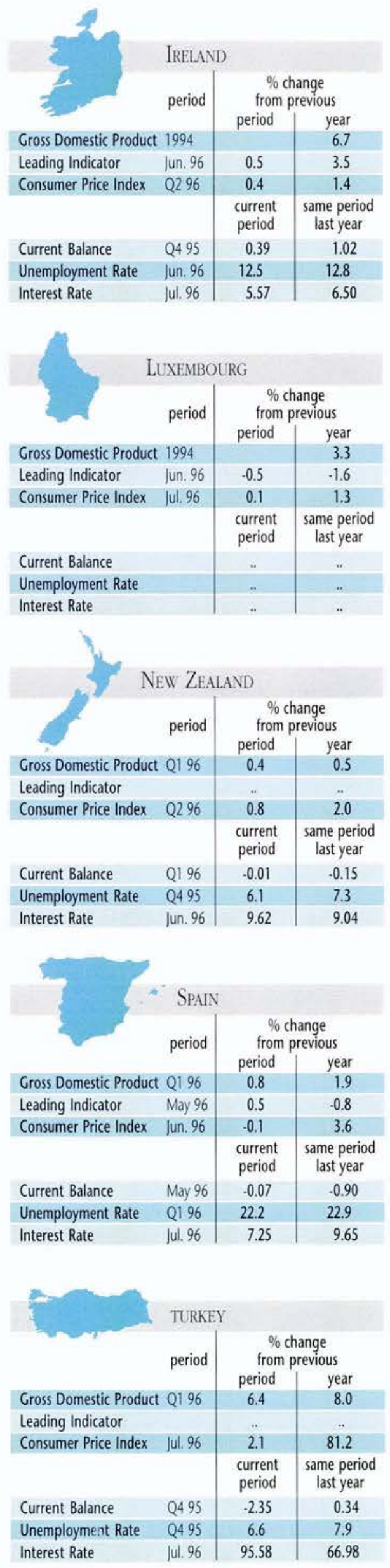
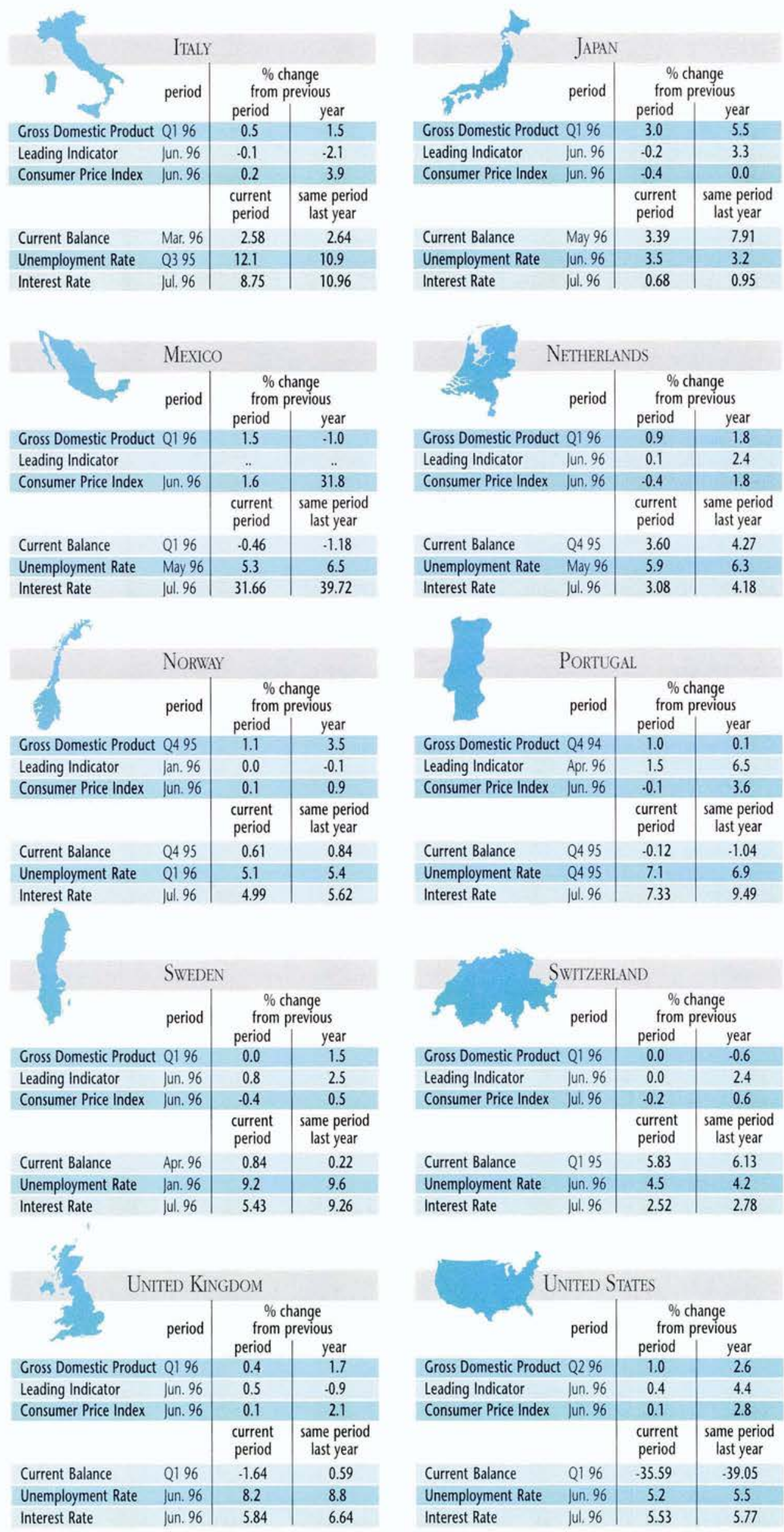


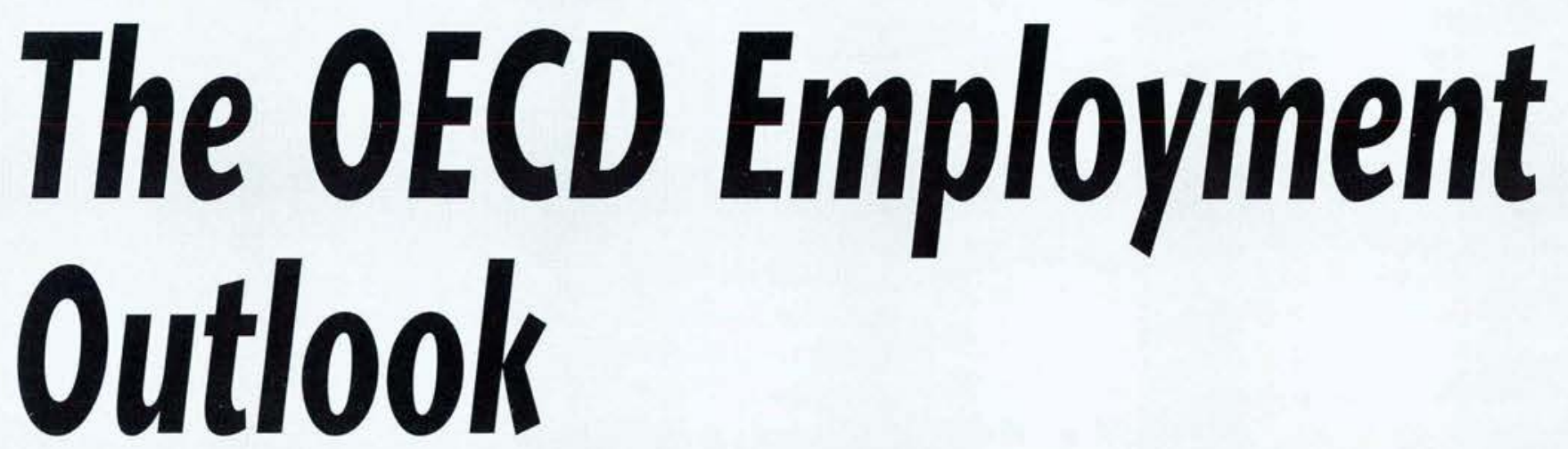

\section{Countering the Risks of Labour-Market Exclusion}

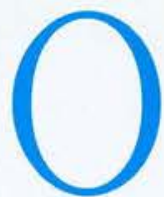

ECD output has grown only modestly over the past two years. In the United States, growth appears relatively strong and has been associated with stable, low inflation and unemployment. In the Pacific region. Australia and New Zealand have recorded continued growth over the past few years; the upswing finally got underway in Japan in late 1995. In Europe, growth has slowed significantly from the second half of 1995 and, in some countries, unemployment rates are again rising. The OECDarea unemployment rate in the first half of 1996 is estimated to be $7.7 \%$, or over $33 \frac{1}{2}$ million people unemployed. The latest projections suggest little improvement in unemployment over the next two years. On the more positive side, inflation is low and contained nearly everywhere, and interest rates have also declined. ${ }^{1}$

High and persistent unemployment is only one manifestation of the poor labour-market performance in many OECD countries. OECD societies also confront some worrying inequalities which are straining the social fabric. In some countries, such as the United States and the United Kingdom, earnings have become considerably more unequal. Moreover, preliminary analysis suggests that, in such countries, the in- crease in earnings dispersion may not be offset in the longer-run by an increase in relative upward mobility among those with low earnings. When inequality widens, this can lead to more marginalisation, an increase in poverty, and exacerbation of budgetary pressure on existing social safety nets. The distribution of work across households in a number of countries has also become more polarised. And, while many workers in temporary jobs do get into permanent ones, a non-trivial proportion also appears to remain in temporary work or move out of jobs altogether.

The risk now facing a number of OECD countries is that labour-market exclusion can easily turn into poverty and dependency. Social-protection systems can alleviate poverty, but they cannot promote participation in society unless they are closely tied to measures to tackle labourmarket problems. A key question is therefore: what role can governments play to enable as many people as possible to construct good labour-market 'careers' in a turbulent environ-

1. OECD Employment Outlook, OECD Publications Paris, 1996.

2. The OECD Jobs Study: Facts, Analysis, Strategies OECD Publications, Paris, 1994.

3. OECD Publications, Paris, 1996. ment, while providing an adequate safety net for those still unable to compete?

The OECD Jobs Study, which was endorsed by ministers in 1994,2 sought to provide answers to this and related questions. Work over the past two years has confirmed that the Jobs Study recommendations were the right ones. It has also highlighted the importance of co-ordinated reforms that achieve both efficiency and equity goals over time, so that unemployment can be reduced and labour-market and social exclusion can be alleviated. In this context, there are three core issues in The OECD Jobs Strategy: Pushing Abead with the Strategy:

- how to reform tax and benefit systems so as to reduce both unemployment and poverty traps - how to improve young peoples ability to make a better transition into the world of work

- how best to ensure the implementation of real commitments to life-long learning in economies beset with a very large turn-over in jobs.

\section{Making Work}

Pay

Taxes and benefits are the most direct way in which governments can affect the financial in- 
centives to accept and to offer work (and alter the after-tax distribution of incomes). If work does not pay, people will be more reluctant to work. For the large majority of the population, there are clear financial rewards to working. But such rewards may be lacking for a significant minority with low potential for earnings. Some features of existing tax and benefit systems give rise to labour-market problems, thereby contributing to higher unemplovment. This is not to suggest that taxes and benefits are the principal cause of high and persistent unemployment. The present malaise in OECD labour-markets stems from many causes and can only be addressed by a broadly based strategy. Nevertheless, it is undeniable that reforms to tax benefit systems have a contribution to make in reducing unemployment in many countries.

Tax benefit systems can cause labour-market problems in three ways. First, they can create the so-called unemployment trap when unemployment and related welfare benefits are high relative to expected net earnings from taking a job. so that the unemploved have little incentive actively to search for one. Second, they can create the so-called 'poverty trap' when workers earning low pay have little or no incentive to raise their earnings by increasing the amount of time and effort in work since they face very high marginal effective tax rates. Third, taxes on labour may increase its cost and reduce employment. Realistic reforms which seek to minimise the adverse effects of these traps on incentives to work must take due account of the original goals of these policies. Taxes must raise revenues, and benefits are intended to provide for those with inadequate incomes. Nearly all reforms which "make work pay" involve trade-offs between these objectives.

The simplest way to attack the unemployment trap would be to cut the generosity of benefits. Some countries have indeed made modest cuts (Austria, Canada, Denmark, Germany. Ireland, New Zealand and Sweden, for example). But the the social costs of this solution may be unacceptably high and it may not much increase work incentives, at least in the regular labour market. Many countries have therefore opted to put more weight on alternative reforms.

For example, some countries have taken action to increase the insurance principle. Canada, where seasonal unemployment is high, is considering reducing entitlements to those who repeatedly become unemploved, partly on the grounds that seasonality in production and employment has been exacerbated by the benefit system - both workers and firms have adapted their behaviour to it. In some other countries, such as Finland, the Netherlands and Spain, reforms affecting access to unemployment benefits (for example, by increasing eligibility requirements) have been implemented.

Another route to cutting the unemployment trap is to tighten administrative controls on jobsearch by the unemployed receiving benefits. This reform has been implemented in countries such as Australia, Belgium. Denmark, Italy, the Netherlands, Spain and the United Kingdom. It is often coupled with targeted job-search assistance and counselling provided by the public employment service. These latter services are important since a consistent message from evaluations of active labour-market policies is that, properly designed and targeted, they have proven their worth in terms of being a costeffective way of raising the probability of an unemployed job-seeker getting into work.

Poverty traps create a different, but related, set of problems. If benefits for the unemploved are completely withdrawn as soon as earnings rise above zero or some very low amount, and taxes and social-security contributions must be paid on these earnings, the financial disincentive to work for only a few hours would be severe. Generally, therefore, benefits are clawed back gradually, The so-called marginal effective tax rate (METR) takes account not only of the rate at which benefits are clawed back, but also of income taxes and social-security contributions. If METRs are very high, people may have little financial incentive to work more. This can be a particularly acute problem for many low-income individuals and households - hence the term poverty trap.
Many relatively high METRs involve OECD countries policies towards families. Payments that are means-tested on family income often have a METR of 100\%: social-assistance benefits fall into this category and, in some countries, the number of recipients of such benefits has risen sharply. Moreover, most special benefits for lone parents are means-tested. The number of people and households facing high METRs varies across countries, but some patterns are clear. Women are more affected than men. The most directly affected group by far is lone parents.

The trend towards more inequality of earnings in some countries, especially the deterioration of the relative and, in some cases, absolute position of the lowest-paid, can be of concern in this respect. Here it matters considerably whether low-paid jobs typically serve as stepping-stones to better ones or as long-term traps. Preliminary evidence shows that upward mobility is fairly high for young workers. It is much lower for adults who experience substantial movement from low-paid jobs to non-employment. These workers are particularly vulnerable to poverty traps and, where their earnings from work have declined, there are incentives to leave the regular labour market altogether.

There are ways to reduce METRs for workers with low earnings, but they inevitably involve a trade-off: either METRs for workers and households further up the earnings distribution will increase, or income-support for those on low incomes will fall. Although reforms can increase work incentives for low-wage workers, the counterpart is reduced work-incentives for workers higher up the earnings distribution. Some research suggests that the increase in work, induced by reforms, by the former group may be roughly equal to the decrease in work by the latter group. Irrespective of the net effect on work effort, there are very good social and longterm labour-market reasons to introduce reforms that both help promote the employment of those who would otherwise be excluded from the labour market and to aid low-paid workers in general.

One reform which has attracted growing in- 
terest is employment-conditional (so-called inwork') benefits. These top-up the income of those in low-paid jobs. The key feature of such a benefit is that it is income-tested, but payable only to those employed. Because it is phasedout as earnings rise, it is wholly targeted on lowpaid workers. Such benefits are currently, in various guises, available in six $O E C D$ countries: Canada, Ireland, Italy, New Zealand, the United Kingdom and the United States.

The success of such schemes in raising workincentives is heavily contingent on a number of factors. On grounds of cost and of the necessary ratcheting-up of high METRs further up the earnings distribution, the benefit must be withdrawn from those earning close to the median wage, that is, a relatively dense part of the earnings distribution. Employment-conditional benefits are thus likely to be most successful in countries where the existing earnings distribution is relatively unequal and the benefits are kept fairly low relative to average earnings. Such schemes are best targeted on families with children because they have high replacement-rates and therefore require higher earnings to make working a more viable option than not working.

Tax and benefit systems also influence the demand for labour because non-wage labour costs can be a disincentive to hiring. In many countries, employers' social-security contributions are the largest of these costs and contributions may sometimes be structured in a regressive way, meaning that a large part of the burden falls on low-wage labour. Employers' contribution rates increased in eight countries over the 1980s, often substantially, while they dropped significantly in only five.

Many countries (Belgium, France, Germany, Ireland, Italy and the Netherlands, for example) have recognised the problem. In particular, attempts have been made to target rate reductions on either low-wage workers or new hires of the long-term unemployed. But these inevitably involve both 'dead-weight' costs some people would have been hired anyway in the absence of the cut in social-security contributions - and 'displacement' effects - some new workers are substituted for existing employees. As a result, these schemes are not self-financing and tax increases elsewhere to offset revenue losses may involve adverse effects on employment.

Public-finance considerations are only one of the multiple objectives which tax and benefit systems are pursuing: others include insuring against labour-market risk, supporting families without adequate resources, and preserving incentives to work. It is inevitable that not all of these objectives can be achieved simultaneously. But some reforms to tax and benefit systems are an essential part of the OECD Jobs Strategy. Although cuts in benefits are sometimes necessary, they risk exacerbating poverty. But there are many avoidable barriers to employment where trade-offs may be less severe, such as those caused by administrative complexities, poor integration of the various parts of tax and benefit systems and badly designed meanstests.

A strong case can be made for targeting tax and benefit reforms on groups that face particular difficulty integrating into the labour market - for example, jobless young people trying to make the transition from educational participation to the job market, the long-term unemploved and lone parents. Such targeting is justified because the expected longer-term gains from providing work-experience to the target groups, thus increasing future employability, can outweigh the shorter-term costs. The alternative is permanent marginalisation of part of the population from the world of work, with consequences which are apparent in too many countries.

\section{Problems for Young People}

The current economic and social state of many young people falls far short of what is desirable. Although more young people participate longer in education, with potential long-run pay-offs for them and society, as many as one-fifth leave school without the prerequisite knowledge, skills or qualifications required for jobs in today's economy. Youth employment rates have fallen since 1979 in most countries, often substantially, particularly among young men. Many countries have also recorded an increase in the proportion of teenagers and young adults neither in work nor in education. The proportion of the voung unemployed in households where no other member is employed has also tended to increase.

It is not just a youth problem;. As long as total unemployment remains high, it is unrealistic to expect a significant improvement in youth job prospects: both the employment and unemployment rates of young people are highly responsive to the overall state of the labour market. Policies that attack the causes of high and persistent unemployment will also improve labourmarket outcomes for young people.

This is a necessary, but hardly sufficient, condition. Problems appear particularly severe for young, out-of-school men: in most countries their emplovment rates have trended downward over the past $15-20$ years. They are likely to have the least educational qualifications among the youth population. Although the evidence is limited, the collapse of this part of the vouth job market must partly reflect the shift in the composition of labour demand toward more experienced and skilled workers.

For this group in particular, policies have to focus on facilitating their access to jobs and on developing the requisite skills. This is not an easy task. A number of countries expanded their active labour-market policies (ALMPs) for vouths considerably during the 1980 s, but the results, on average, are not encouraging. Although some were helped, for many it simply represented recrcling from joblessness to a brief spell on a programme and back again - the so-called carousel effect.

One lesson from the evaluation literature is that most ALMPs do not help out-of-school youths unless they are combined with other programmes explicitly targeted at their specific labour-market requirements. Many young people enter programmes with multiple disadvantages 
stemming from where they live, their household resources and their experience in school.

Another lesson from the evaluation literature is that early intervention is vital in terms of improving prospects later. By the time a young person leaves school, it is usually very difficult and costly for ALMPs to overcome the handicaps of poor educational preparation and the demotivation that can accompany it. Preventing educational failure is a community and societal responsibility. Here, improving early childhood development and care is essential. Early intervention can help overcome some of the many disadvantages suffered by children from 'at-risk' backgrounds and communities. This is not only a question of social equity but also a key factor in improving the longer-term health of OECD economies.

Policies that contribute to reducing early school-leaving are therefore critical since anything less than a sound upper-secondary education, or its equivalent vocational qualification, may be associated with low earnings-capacity and is insufficient preparation for getting into the job market and for access to further learning. Tackling this problem requires the combined efforts of families, employers, unions, government and the community at large. The common features of countries that do relatively well in preparing their young people for working life are ensuring diversity in content, teaching and learning methods in upper-secondary education, and in providing viable pathways back into education and training for those who leave school early.

\section{Life-long Learning}

The problems extend beyond schools and young people. The first International Adult Literacy Survey found that up to one-fifth of the population aged $16-65$ in seven advanced economies can only perform at the most basic standards of literacy and numeracy.' This is far short of what is required for employment in good jobs in today's economy. These people are at high risk of joblessness with the slew of social costs which it entails.

High rates of job turn-over, significant numbers of prime-age and older workers trapped in low-paid employment, and considerable yearon-year volatility in earnings simply reinforce the point: many workers will have to be able to enhance their skills continually if they are to have the opportunity to move up the ladder or bounce back from setbacks, such as losing their jobs.

At their January 1996 meeting, OECD education ministers urged that high priority be placed on implementing strategies for system-wide change - from early childhood education to learning opportunities throughout life. This will require a more fluid relation between learning and work, where an initial period of full-time education is followed by various combinations of work, training and education in enterprises and educational institutions.

Succesfful strategies for life-long learning will require substantially increased co-ordination across ministries, and rethinking of the roles and responsibilities of all who provide opportunities for learning. They will probably also require increased investment in human capital and the assurance that those with insufficient resources to fund additional education/training or who are locked in jobs where learning opportunities are limited are not left behind.

Moreover, investment in further education and training is very unevenly distributed across the work force in most countries, to the severe detriment of those with fewer skills and lower educational attainment. The private and social costs of such unequal access to upgrading skills and competencies are clear. A more equitable distribution of training could therefore enhance future productivity, thereby leading to higher growth and employment.

Businesses, trade unions and the public sector all have roles to play in overcoming existing

4. See pp. 26-29.

5 Literacy, Economy and Society. OECD Publications.

Paris, and Statistics Canada, Ottaua, 1995.

6. The OECD Observer, No. 199, April/May 1996. barriers to investments in learning. Market forces alone are unlikely to overcome the considerable uncertainty of the returns and costs to investments, the capital constraints facing individuals or the problem of free-riding - one firm's investment adding to the pool of abilities for others to buy in more cheaply than if they had undertaken the investment themselves.

So the proper incentives have to be created if new resources for life-long learning are to be mobilised without further demands on the public purse. Taking account of countries' different circumstances and priorities, some new balance must be developed in the contributions expected of individuals, employers and unions and society as a whole. Past experience with financial incentives such as training levies, subsidies or vouchers has been quite mixed. Earnings differentials can play a role as incentives for workers to invest in skills. But they are not a panacea: the structure of wages is driven by many factors other than differences in the return to human capital and those trapped in low-paid jobs often have little incentive, or the financial means, to invest in further education and training. For these reasons, education ministers have called on the OECD to examine carefully alternative policies and incentives to encourage life-long learning in a costeffective and equitable fashion.

The future prosperity of $\mathrm{OECD}$ countries depends on reducing economic and social exclusion in the forms of high unemployment, non-participation in the labour market, lack of access to further learning opportunities and, in some instances, growing inequalities in earnings and incomes. It is more important than ever that policies - labour, social and educational, as well as macro-economic - be co-ordinated and coherent. Designing and re-designing a range of policies, as well as institution-building, will be required. This will take time, but it is the only way to increase the adaptability and resilience of modern societies. 


\section{Order Form at the end of the issue}

\section{Economy}

OECD Economic Surveys*

Finland 1995-1996

July 1990

(10 96,31 1) ISBN $92-6+-1527-3-3,72 \mathrm{pp}$.

Switzerland 1995-1996

July 1096

(10 96.261 ) ISB $92-6+1+913-9,156 \mathrm{pp}$

The Czech Republic 1996

July 1996

(10 96321) 15BX 92-6+-14909-0. 120pp

FF145 L'S526 DN10

ISS $>0376-6438$

1696 Suhscription

FF1. 750 ISS 385 DN550

Also available as an electronic book.

\section{Development and Aid}

OECD Development Centre

\section{Migrants}

Partners in Development

Co-operation

July 1996

Are migrants more than a politically sensitive issue in an increasing number of countries - mere escapees from underdevelopment - or have they a positive contribution to make to the development of their countries of origin? This book examines this question on the basis of a series of specially commissioned case studies.

The authors conclude that not only do migrants play a part in the developmental dynamics of their home countries, but that they would take an even larger role if policies were adopted in sending and receiving countries which would facilitate this process. The study argues for the recognition and encouragement of this partnership for development and points out ways of putting it into practice

(41 9606 1) ISBN 92-64-14907-4, 60pp.

$\mathrm{FF}(0)$ (SS12 $\mathrm{DMH}^{-}$

Integrating Biotechnology in Agriculture
Incentives, Constraints and Country Experiences July 1996

Worldwide concern for agriculture that is more environmentally friendly has provoked interest in agricultural biotechnology, particularly in developing countries. Although many have embarked on biotechnology research. few biotechnology applications have vet to reach the field. This study, based principally on country experiences, calls for an integrated approach to biotechnology in which national priorities for research are firmly linked to the objectives and problems of agriculture. It also argues in favour of public-private-sector partnerships and for long-term funding from the donor community. (41 9605 1) ISBN 92-64+14901-5, 97 pp. FFIO0 [SSIT DMES

Development Centre Studies Long-term Growth Series

Long-Term Growth in Tunisia

August 1996

Although Tunisia appears to have enjoved satisfactory growth since 1960 with average annual GDP at $5.3 \%$, different policies produced very different results over the period. Tunisia did display consistent improvements in education, physical infrastructures, income distribution, social mobility and a modernising outlook.

The authors of this study argue that Tunisia should build upon its comparative advantages to benefit from reduced. more efficient state intervention. Policies should be designed to foster appropriate industrial activities, attract foreign investment and capitalise on the country's natural advantages. (11 9607 1) [SB 92-64-14925-2, 135pp. FF115 LSS23 DNB3-

Development Co-operation Review Series 1996

Austria No. 15

June 1996

The Development Assistance Committee $(\mathrm{DAC})$ reviews are regular peer examinations of each DAC member's development-assistance policies and programmes, and are unique to the
1. Employment Outlook, July 1996

(81 9608 1) ISBN 92-64-14900-7, July 1996, 212 pp.

Price: FF $305 \& 39$ USS 60 DM 89

2. Historical Statistics $1960-1994$

1996 Edition

(30 9609 3) ISBN 92-64-04850-2. Bilingual, July 1996, 180 pp. Price: FF 200 \& 26 USS 39 DM 59

3. OECD Economic Surveys

The Czech Republic 1996

(10 96 32 1) ISBN 92-64-14909-0, July 1996, 120 pp.

Price: FF $145 \$ 16$ USS 26 DM 40

4. OECD Economic surveys

Switzerland 1995-1996

(10 9626 1) ISBN 92-64-14913-9. July 1996, 178 pp.

Price: FF 145 \& 16 US\$ 26 DM 40

5. Energy Balances of OECD Countries 1993-1994

(61 96 17 3) ISBN 92-64-04845-6. Bilingual, July 1996. 276 pp.

Price: FF $330 \& 43$ LSS 65 DM 97

6. The OECD Job Strategy

Enhancing the Effectiveness

of Active Labour Market Policies

(81 9607 1) ISBN 92-64-14908-2, July 1996, 48 pp.

Price: FF 65 \& 8 USS 13 DM 19

7. OECD Economic Outlook, No. 59, June 1996

(12 9659 1) ISBN 92-64-14713-6, June 1996, 224 pp.

Price: FF $180 \& 21$ USS 35 DM 55

8. Development Centre Studies

Integrating Biotechnology in Agriculture: Incentives, Constraints and Country Experiences

(41 9605 1) ISBN 92-64-14901-5. July 1996, 99 pp.

Price: FF $100 £ 13$ USS 19 DM 28

9. Labour Market and Social Policies in the Slovak Republic

(1496 10 1) ISBN 92-64-14830-2, July 1996, 176 pp.

Price: FF $210 \& 27$ USS 40 DM 60

10. Development Co-operation Review Series 1996 Italy No. 16

(43 96 10 1) ISBN 92-64-14902-3, July 1996, 56 pp.

Price: FF $85 \& 11$ USS 17 DM 25 
OECD. This series makes available the Committee's Summary and Conclusions as well as the OECD Secretariat reports prepared for these reviews along with their supporting statistical material.

Development co-operation policy reviews in 1996 are planned for the following DAC members: New Zealand, Australia, Sweden, Portugal, Switzerland and France.

(43396 08 1) ISBN 92-64-14889-2. 62pp

FF85 US517 DN125

Italy No. 16

July 1996

(4396 10 1) ISBN $92-6+14902-3,60 \mathrm{pp}$

FF85 ISS17 DN25

\section{Education}

Centre for Educational Research

and Innovation

OECD Documents

\section{Knowledge Bases}

for Education Policies

July 1996

The importance of knowledge in emerging systems of life-long learning has become crucial. Previous CERI work has clearly shown that policy-makers require relevant educational $\mathrm{R} \& D$ to help determine educational policy. Yet policy-makers have to rely also on other forms of knowledge bases than that of R\&D, such as inspector and indicator systems, both nationally and internationally. The use of a broader range of knowledge bases highlights the important role of 'mediators' who can facilitate the necessary communication and reciprocal enrichment between knowledge-producers, decision-makers and practitioners.

The importance of further clarifying and understanding this process of production, mediation and use of different forms of knowledge is likely to grow in importance in emerging learning economies and knowledge societies. $(9696031$ 1) ISBN $92-6+14895-7,174 \mathrm{pp}$ FF190 USS37 DN55

\section{PEB Exchange No. 28}

June 1996

(88 9628 1), 20pp.

ISSN 1018-9237

1906 Subscription

FFl 60 USS 3 - DN 48

\section{Employment and Social Affairs}

The OECD Job Strategy
Enhancing the Effectiveness
of Active Labour Market Policies
July 1996
Active labour-market policies are de-
signed to assist the unemployed in
searching and applying for jobs success-
fully. Spending public money for this
purpose is generally considered to be
more useful than providing only
passive income support to the unem-
ployed. But several studies suggest that
many active labour market programmes
do not achieve their objectives.
How can active measures be made
more efficient the best to combat un-
employment? Based on the recent
history of active and passive labour-
market policies in 12 OECD countries,
this publication provides concrete pro-
posals for improving public employ-

ment services and for co-ordinating unemployment-benefit measures and active labour-market policies. (81 9607 1) ISBN 92-64-14908-2. $41 \mathrm{pp}$ FF65 LSS13 DM19

\section{CCET (Centre for Co-operation} with the Economies in Transition)

\section{Labour Market and Social Policies in the Slovak Republic}

July 1996

Although macro-economic performance has improved in the Slovak Republic, high unemployment continues and the incidence of long-term unemployment is increasing. The Slovak authorities should not react to increasing labourmarket hardship by slowing down the privatisation process and creating impediments to restructuring. This book offers a blueprint for labour-market and social policies that could enhance the job-generation potential of economic recovery.

See Tito Boeri and Douglas Lippoldt, 'The Labour Market in Slovakia'. The OECD Observer. No. 198, February/ March 1996.

(1496 10 1) ISBN 92-64-14830-2. 176pp. 192 p. FF210 USS +0 DM60

\section{Energy}

\section{IEA (International Energy Agency)}

Climate Technology Initiative Inventory of Activites

June 1996

New and improved technologies will be an indispensable part of efforts to meet the objectives of the UN Frame- work Convention on Climate Change (FCCC). To respond to this challenge in a cost-effective way $23 \mathrm{OECD}$ countries announced the Climate Technology Initiative (CTI) at the 1995 Berlin Conference of the Parties to the FCCC.

The purpose of the $\mathrm{CTl}$ is to promote and accelerate the development and deployment of more climate-friendly technologies. The CTI is a projectoriented vehicle to establish and optimise practical government and industry co-operation internationally, with projects involving parties from government, academia and industry from inside and outside the OECD. It will re-inforce efforts to improve the availability of commercial technologies, and efforts to develop and deploy new technologies.

This first CTI Inventory of Activities summarises current activities that have been identified as relevant to the Climate Technology Initiative. With an emphasis on the energy sector, it shows the extent of activity underway in the field of climate-friendly technologies.

The CTI is open to participation by government agencies, academia and industry from all interested countries. The Inventory provides an opportunity for interested parties to identify activities in which they may wish to participate or projects they may wish to launch as new CTI activities which are incorporated into their own strategies for economic development and climate response.

(61 9619 1) ISBN 92-6+14903-1, 96pp.

FF95 LSS19 DN28

\section{Energy Balances of OECD Countries 1993-1994*}

Continued from p. 46

assistance to past earnings, combined with the indefinite nature of unemployment assistance and a rather generous interpretation of what constitutes acceptable work, is also important. Steps have recently been taken by the government to limit the duration of unemployment assistance and to reduce reference wages with unemployment duration, as well as to link social assistance more closely to local earnings opportunities.

The system will nevertheless remain very generous, and consideration might have to be given to restricting still further the ability to refuse job-offers and to increasing the incentives for lower-paid workers to take up employment. Some groups, furthermore, are caught in a welfare trap with very high rates of marginal effective tax. There is thus room for rationalising the tax base and simplifying and reducing tax-rates. Spending on healthcare will have to be curbed further. Over the longer term, entitlements in the public pension system will probably have to be restricted so that it is essential that moves be initiated now to encourage the development of supplementary pensions. The legal and tax barri- ers to the development of private pension funds should therefore be lowered. =

\section{OECD BIBLIOGRAPHY}

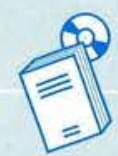

OECD Economic Surveys: Germany, 1996 Patrick Hennessy, 'Paying for Care for the Elderly', The OECD Observer, No. 201, August/September 1996

Willi Leibfritz and Deborah Roseveare, 'Aging Populations and Covernment Budgets', The OECD Observer, №. 197, December 1995//anuary 1996. 
June 1996

Contains a compilation of data on the supply and consumption of coal, oil. gas, electricity, heat, combustible renewables and waste presented in energy balances. The figures are expressed in million tonnes of oil equivalent. Historical tables summarise kev energy and economic indicators as well as production, trade and final consumption data. Each issue includes definitions of products and flows and explanatory notes on the individual country data as well as conversion factors from original units to tonnes of oil equivalent.

$(6196173$ ) 1SBN $92-64-04845-6$, bilingual, 276pp FF 330 US\$65 DN97

Also available on diskette and magnetic tape.

\section{Energy Statistics of OECD Countries 1993-1994* \\ June 1996}

Contains a compilation of energy supply and consumption data in original units for coal, oil, gas, electricity, heat. combustible renewables and waste. Historical tables summarise data on production, trade and final consumption of hard coal, brown coal, oil. natural gas and electricity. Each issue includes definitions of products and flows and explanatory notes on the individual country data.

The data contained in this publication are presented in comprehensive energy balances expressed in million tonnes of oil equivalent in Energy Balances of OECD Countries. 1993-1994. the sister volume of this publication. (61 9618 3) ISBN 92-64-04846-4, bilingual, 360pp FF 290 U) USS58 DNI86

- Also available on diskette and magnetic tape

\section{Energy Prices and Taxes* First Quarter 1996}

July 1996

Contains a major international compilation of energy prices at all market levels: import prices, industry prices and consumer prices. The statistics cover main petroleum products, gas, coal and electricity, giving for imported products an average price both for importing country and country of origin. Every issue includes full notes on sources and methods and a description of price mechanisms in each country.

(629603 1) ISBN 92-64-14766-7, 370pp.

FF350 USS 70 DM95

ISSN $0376-6+38$

1996 Subscription

FF1. 150 [SS230 DM 330
NEA (Nuclear Energy Agency)

Newsletter

Spring 1996, Vol. 14, No. 1

July 1996

(689601 1) ISBN 92-64-14730-6, 4ipp)

1996 Subscription

FF160 US532 DN52

Nuclear Law Bulletin

Supplement to No. 57

July 1996

(670601 1) ISBN 92-64-14855-X. 1000p. FF105 LS521 DM30

\section{Financial, Fiscal and Enterprise Affairs}

\section{Financial Market Trends \\ No. $64^{*}$}

June 1996

Special Features

- Recent trends in privatisation

- Recent trends in foreign direct invest-

ment

- Policy issues in insurance: invest-

ment, taxation, insolvency

(279602 1) ISBN 92-64-14711-X, 170pp

FF130 LSS25 DM3?

ISSN 0378-651X

1996 Subscription

- Also avaliable as an elcctonic book

\section{National Accounts}

Detailed Tables

Vol. II, 1982-1994*

August 1996

Two publications provide annual national accounts statistics compiled according to the joint UN-OECD System of National Accounts - Vol, I: Main Aggregates; and Vol. II: Detailed Tables.

Quarterly national-accounts statistics, based on each country's own system of national accounts, are published in the OECD quarterly bulletin. Quarterly National Accounts.

(3096 08 3) ISBN 92-64-04852-9, bilingual, 620 pp. FF670 USS132 DM196

-Also available on diskette and magnetic tape

Quarterly National Accounts Sources and Methods Used by OECD Member Countries

July 1996

National accounts have long been established as the essential indicator of economic development. But their use for monitoring current developments is limited if they are available only once a vear. In recognition of this, most OECD countries have started to estimate national accounts on a quarterly basis.
This publication serves as a practical manual for statisticians responsible for initiating or improving quarterly estimates, and as a guide for analysts and other users to assess the reliability of quarterly accounts.

(360605 i) ISBN $92-6+14899-\mathrm{X}, 178 \mathrm{pp}$ FF 275 LCS5i DUSO

\section{Industry, Science and Technology}

\section{Main Science and Technology Indicators 1996/1* \\ June 1996}

This twice-yearly, bilingual publication contains data on the scientific and technological performance of the OECD countries. It summarises and updates the OECD Basic Science and Technology Statistics published every two years (annually on diskette).

These data include final and provisional results and government forecasts covering such topics as resources devoted to R\&D, patents, the technology balance of pavments, and international trade in high-technology products. Supporting background economic series are also included.

(949601 3) ISBN 92-64-04-52-2, bilingual, 78pp FF160 USS32 DM 49

ISSN 1011-792X

1996 subscription

FF280 US555 DMS5

Also available on diskette

\section{Tourism}

\section{Tourism Policy}

and International Tourism

in $O E C D$ Countries

1993-1994

\section{Edition 1996}

July 1996

This report compiles and analyses data on international tourist flows and related receipts and expenditure in $\mathrm{OECD}$ countries, which account for about $70 \%$ of the world's tourism. It comments on trends. and reports on government policies and activities which reflect changing objectives and priorities. It focuses on the development and organisation of the tourism industry and. above all, highlights the increasingly important role of the complex and multidisciplinary tourism industry.

130 tables and 12 charts

(78 9601 1) ISBV $92-6+-1+596-5,270 \mathrm{pp}$ FF255 LS550 DM74

\section{Employment Opportunities}

\section{OECD Headquarters, Paris}

Vacancies occur in the OECD Secretariat in the following activities:

Public Administration

Balance of Payments

National Accounts

Agricultural Economics

Development Economics

Energy Economics

Industrial Economics

Labour Economics

Monetary Economics

Econometrics

Environment

Uiban Studies

Fiscal Policy

Nuclear Engineering

Nacro-Economics

Nuclear Physics

Education Policies

Social Affairs

Statistics

Computing and Communications

\section{Qualifications:}

relevant university degree; at least two or three vears' professional experience; very good knowledge of one of the two official languages of the Organisation (English and French) and ability to draft well in that language; good knowledge of the other

Initial appointment: two or three years.

Basic annual salary: from FF 300,000 (Administrator) and from FF 430.000 (Principal Administrator), supplemented by allowances depending on residence and family situation. Vacancies are open to candidates from $O E C D$ member countries $\mathrm{OECD}$ is an equal opportunity emplover and encourages applications from female candidates. Applications, in English or French (specifying area of specialisation and enclosing detailed curriculum vitae), should be marked 'OBS' and sent to:

Personnel Division OECD 2, rue André-Pascal 755775 Paris Cedex 16 France 


\section{The OECD OBSERVER}

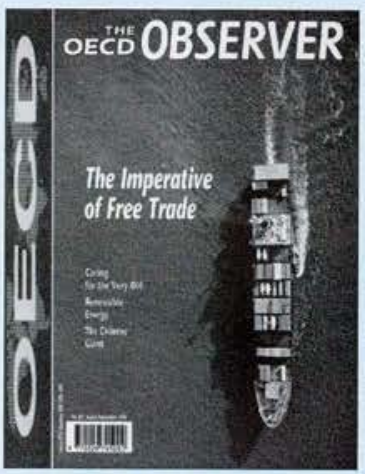

For concise, up-to-date and authoritative information on world economic and social problems, subscribe to The OECD OBSERVER.

Recent articles include: The Imperative of Free Trade $\bullet$ How Competition Helps the Internet $\bullet$ Fiscal Consolidation and Monetary Policy • China Enters the 21st Century • The Growing Strength of Services • West Africa in 2020 - Lower Military Spending in the Regions - Cities and the Global Economy • Aging Populations and Government Budgets • Urban Transport in Eastern Europe - Globalisation and Industrial Competitiveness $\bullet$ Integrating Environment and Economy • Testing Pesticides $\bullet$ Whither Railways? $\bullet$ Revaluing Wetlands $\bullet$ The School of the Future

\section{Quarterly Labour Force Statistics}

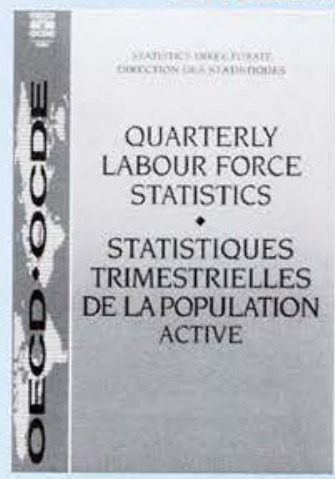

\section{OECD Working Papers}

OECD DOCUMENTS

Information Technology and the Future

of Post-secondary Education

To permit comparisons for 17 OECD countries, statistics are included on total and civilian labour force, unemployment by age and sex, broad industry breakdown of employment. unemployment rates and youth unemployment; standardised unemployment rates. This publication gives data for the last 23 quarters.

Provide the most recent analysis and statistics on the subjects they cover, and include many differing viewpoints and opinions.

A wide range of subjects is covered, such as the latest research by the OECD on macro-economics, industry and labour; education, environment, trade, science and technology, aid and development, fiscal affairs, energy, agriculture, urban studies, economies in transition, and much more. These papers constitute a unique source of information and coverage of the major socio-economic problems facing the world today.

Main Economic Indicators<smiles>[C+]1C[As]1</smiles>

MAIN ECONOMIC INDICATORS PRINCIPAUX INDICATEURS ÉCONOMIOUES
This publication is the essential source of short-term statistics for OECD countries. It provides a complete and timely picture of the most recent changes in the economies of the $O E C D$ countries and puts them in an international context.

The corresponding montbly diskette gives ten years of montbly or quarterly time-series for the same indicators, documented electronically and easy to select for your own analysis.
Return this order form in a stamped envelope

- to the OECD Publications Service in Paris

- to the OECD Publications Distributor in your country, or

- to the OECD Centre in Bonn, Mexico, Tokyo or Washington

Addresses on inside back cover

Return this order form in a stamped envelope

- to the OECD Publications Service in Paris

- to the OECD Publications Distributor in your country, or

- to the OECD Centre in Bonn, Mexico, Tokyo or Washington

Addresses on inside back cover

Return this order form in a stamped envelope

- to the OECD Publications Service in Paris

- to the OECD Publications Distributor in your country, or

- to the OECD Centre in Bonn, Mexico, Tokyo or Washington

Addresses on inside back cover

Return this order form in a stamped envelope

- to the OECD Publications Service in Paris

- to the OECD Publications Distributor in your country, or

- to the OECD Centre in Bonn, Mexico, Tokyo or Washington 
Subscription

FF145 US530 DM46 £20

Supplement for rapid airmail: consult the OECD

For Visa credit-card payment, please indicate: Card No.

Expiry Date

Date

Signature

1997 Subscription

FF270 US\$60 DM90 £35

Supplement for rapid airmail: consult the OECD

For Visa credit-card payment, please indicate: Card No.

Expiry Date

Date

Signature

1997 Subscription

FF3,300 US\$650 DM1,030 £430

approximately 120 issues per year

Supplement for rapid airmail: consult the OECD

For Visa credit-card payment, please indicate: Card No.

\section{Expiry Date}

Date

Signature

1997 Subscription

FF1,450 US\$290 DM420 £180

Supplement for rapid airmail: consult the OECD

For Visa credit-card payment, please indicate: Card No.

Expiry Date

Date

Signature

\section{OECDD OBSERVER}

$\square$ ENGLISH $\square$ FRENCH
SURNAME (in capitals)/FIRST NAME

\section{PROFESSION}

ADDRESS $\square$ HOME $\square$ BUSINESS

POSTCODE-TOWN/CITY

COUNTRY

\section{Quarterly Labour Force Statistics}

BILINCUAL

SURNAME (in capitals)/FIRST NAME

\section{PROFESSION}

ADDRESS $\square$ HOME $\square$ BUSINESS

POSTCODE-TOWN/CITY

COUNTRY

\section{OECD WoRkING Papers}

$\square$ ENGLISH
SURNAME (in capitals)/FIRST NAME

PROFESSION

ADDRESS $\square$ HOME $\square$ BUSINESS

POSTCODE-TOWN/CITY

COUNTRY

\section{MaIN ECONOMIC IndicatoRs}

BILINGUAL

SURNAME (in capitals)/FIRST NAME

monthly

\section{Other OECD Publications}

$\square$ ENGLISH FRENCH
\begin{tabular}{|l|l|}
\hline Title & OECD COde* \\
\hline & \\
\hline & \\
\hline & \\
\hline & \\
\hline & \\
\hline & Ifarailable \\
\hline
\end{tabular}

Forpublications mentioned in arficles in THE OECD OBSERIER, please contaci the OECD Publications Service forprices

\section{Other OECD Publications}

\begin{tabular}{|l|l|}
\hline ENGLISH \\
\begin{tabular}{|l|l|}
\hline FRENCH & \\
\hline Title & OECD Code \\
\hline & \\
\hline & \\
\hline & \\
\hline & \\
\hline & \\
\hline
\end{tabular} \\
\hline
\end{tabular}

\section{Other OECD Publications}

\begin{tabular}{|c|c|}
\hline \multicolumn{2}{|c|}{ ENGLSH } \\
\hline & OECD Code" \\
\hline & \\
\hline & \\
\hline & \\
\hline & \\
\hline & Ifanitable \\
\hline
\end{tabular}

\section{PROFESSION}

ADDRESS $\square$ HOME $\square$ BUSINESS

POSTCODE-TOWN/CITY

COUNTRY 


\begin{tabular}{|c|c|}
\hline $\begin{array}{l}\text { FRANCE } \\
\text { OECD } \\
\text { Mail Orders } \\
2 \text { nue Andrisascal } \\
75775 \text { Paris Cevex } 16\end{array}$ & 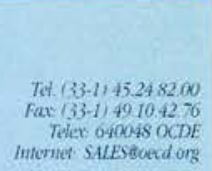 \\
\hline \multicolumn{2}{|c|}{$\begin{array}{l}\text { Orders cia Mimitel France only: } \\
36150 \mathrm{CDE}\end{array}$} \\
\hline $\begin{array}{l}\text { Lihraine de FOCDE } \\
33 \text { nue Octace Feerillet } \\
75015 \text { Pans }\end{array}$ & Te. $\begin{aligned}(33-1) & 45.2481 .81 \\
(33-1) & 45.2481 .67\end{aligned}$ \\
\hline $\begin{array}{l}\text { CERMANY } \\
\text { OECD Bomm Centre } \\
\text { Alugust-Bebel-Allee } 6 \\
D .53175 \text { Bom }\end{array}$ & $\begin{array}{r}\text { Tel. }(0228), 959.120 \\
\text { Fax }(0228), 059,12.17\end{array}$ \\
\hline $\begin{array}{l}\text { JAPAN } \\
\text { OFCD Tolyo Centre } \\
\text { Landic Akasalua Building } \\
2-3-4 \text { Alusalua, Minato-ku } \\
\text { Tokio } 107\end{array}$ & $\begin{array}{l}\text { Tw }(81,3) 3586.2016 \\
\operatorname{Fax}(813) 3584.7929\end{array}$ \\
\hline 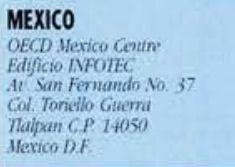 & $\begin{array}{l}\text { Tel }(525) 665+799 \\
\text { Fax: } 1525,600,15.07\end{array}$ \\
\hline 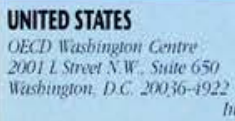 & 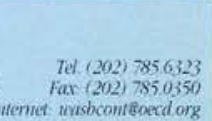 \\
\hline
\end{tabular}

AUSTRALIA

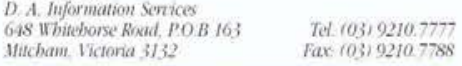

\begin{tabular}{l}
\hline AUSTRIA \\
$\begin{array}{l}\text { Gerold } 6 C_{0} \\
\text { Grahen } 31 \\
\text { Wien I }\end{array}$ \\
\hline
\end{tabular}

\section{BELCIUM}

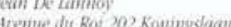

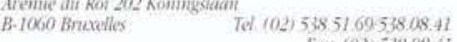

Fax: 02,538 as 4 )

\section{CANADA}

Revouif Pabistering Company tud

Otaua, ON KIB 3 irs

Stones:

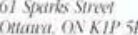

12. Adelaide sireet Hes

Toronto ON $1 / 5 H 1160$

Les Editions La Libne the

sainte-For. PQ GIX 316

Federal Probications fruc

165 Chiversify Atemuc, Suite 701 Tel (416) 860.1611

Poromta ON W5H $3 B S$ Fax 7176$) 850.1608$

Les Publications Fivicrales

1185 tinitersite

Tal: $1514195+1633$

\section{CHINA}

China National Pubrications Impont

Export Conforallon (CNPIEC)

16 Gongti E Road, Claoung District

PO Box 88 or 50

Tet $(01) 5060608$

\section{CHINESE TAIPEI}

Good Faitb Wondduide Imt?. Co. thd

oth Fhoor to IIS ser

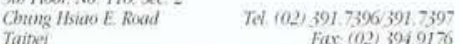

Far 1021394917

\section{CZECH REPUBLIC}

Vational Information Centre

NTS - prodegme

Konuiktaki 5
Praba 1 11357

Tel. 6013$) 711.533$

Fo. 16131238.8985

Tow (1416) 363,317

Fax $1416+363.59 .63$

Tol $(418) 658 ; 763$

-

\section{DENMARK}

Wtunbsgaund Book and Suikcription Semrice

DK-1016 Kobethan K Fax 1331129387

IH. Schultz Information AS.

Herstediang 12 .

Fax: 13312.938

K-2620 Alibersium

Tel. 143,632300

internet s-infoginet inti-c.de

\begin{tabular}{|c|c|c|c|}
\hline 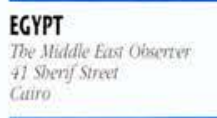 & $\begin{array}{r}\text { 7el } 392.6919 \\
\text { Fax } 360-6804\end{array}$ & \multirow{2}{*}{ 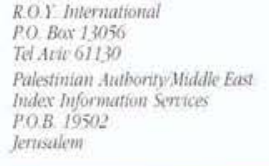 } & \multirow[t]{2}{*}{$\begin{array}{l}\operatorname{Tel}(3) 546.1423 \\
\operatorname{Fax}(3) 546.1442 \\
\operatorname{Te}(12) 2712.19 \\
\operatorname{Fax}(2) 27.16 .34\end{array}$} \\
\hline FINLAND & & & \\
\hline 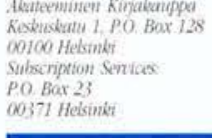 & $\begin{array}{l}\text { Tel. }(358 \text { o) } 121.4116 \\
\text { Fax }(3580 \text { o) } 121.4450\end{array}$ & $\begin{array}{l}\text { ITALY } \\
\text { Libreria Commussionana Sansonf } \\
\text { 1ha Dica di Calahria it/ } \\
50125 \text { Firenze } \\
\text { Lia Bamtolini } 29\end{array}$ & $\begin{array}{l}\text { Tel } 1055) 64.5415 \\
\text { Fax } 1055,641257\end{array}$ \\
\hline $\begin{array}{l}\text { FRANCE } \\
\text { See bex }\end{array}$ & & $\begin{array}{l}\text { 20155. Milano } \\
\text { Editrice e Libreria Herder } \\
\text { Piazza Montecitorio } 120 \\
\text { COIS6 Roma }\end{array}$ & $\begin{array}{l}\text { Tel } 679.46 .28 \\
\operatorname{fax} 678.4753\end{array}$ \\
\hline $\begin{array}{l}\text { Datuson } \\
\text { B.P. } 40 \\
\text { 92121 Palaiseru Cidex }\end{array}$ & $\begin{array}{l}\text { Ted } 691047000 \\
\text { Fax } 64.548326\end{array}$ & $\begin{array}{l}\text { Librenia Hoeplt } \\
\text { Via Hoctit } 5 \\
20121 \text { Milano }\end{array}$ & $\begin{array}{r}\text { Tel. } 102) 86.51 .46 \\
\operatorname{Fax}(02) 805.28 .86\end{array}$ \\
\hline $\begin{array}{l}\text { 29. yuar Voltaire } \\
75007 \text { Parts }\end{array}$ & $\mathrm{Tel}+40.15 .70 .00$ & $\begin{array}{l}\text { Librena Scientifica } \\
\text { Dott. Lucio de Biasso Aeiou }\end{array}$ & \\
\hline $\begin{array}{l}\text { Economica } \\
\text { 19. nie Hincant } \\
75015 \text { Pars }\end{array}$ & $\begin{array}{l}\text { Tel } 45.78 .12 .92 \\
\text { Fax } 45.7505 .67\end{array}$ & $\begin{array}{l}\text { Via Comonelli } 6 \\
201+6 \text {. Mtiano }\end{array}$ & $\begin{array}{r}\text { Tel }(02) \quad 48.95 .45 .52 \\
\text { Fax }(102) \\
48.95 .45 .48\end{array}$ \\
\hline
\end{tabular}

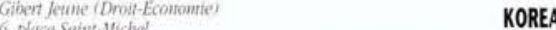

a. place saimisiliche

finnairie dis Commerce lnternational

1. 4325.91 .19

10 aremue d lema
75016 Pars

Lihrume Duanod

Place if Nanichal do Lattre de Tassien?

Tet 40.733460

Kiobo

Te. 730789

Seoul 730.7891
Fax 735.0030

MALAYSIA

Cintersity of Malaya Bookshop

chicersity of Batana

(

Tet 4405.40 .13

thinruirie tavoisier

1. nie Latoiss

Librainie des Sciences Politique

Td 426539.95

75007 Pans

Tel. 45.483602

PLE boulezand Saint-Midel

75005 Paris

Tel +33258340

tibnaine de Thinesis

12a, me Nazareth

Decamentation Françase

165. nie Garihald

thesing

29. place Beflecour

29. place Bellerour
$69002 \mathrm{Ly}$.

limaine Salramps

4e. Trangle

I la Somonic Actual

23. mie de Ithóted des Pootes

(16) 42.26 .1808

Malansia

Tel. 756.50007756 .5425

\section{NETHERLANDS}

SDU Litgeveril Plantijnstrad

Everne Fondse

2500 EA s-Gracentager $\quad T d$ ro70) 3789899

lear besellingen Fax (070) 34.75 .778

Suhscription Agenc.
Suets z Z Zeitligger B1.

Hereuce 347 the

PO. Bar 830

Tet. (16) $78.63,32.23$

2160 \$ L Lisse

Tel. $252+35.111$

\section{NEW ZEALAND}

GP Legstation Sen
PO Box $12+18$

Tel. $(16) 67.58 .85 .15$

Thorndon, Wellingoton

Ted $1071+96.5655$

NORWAY

NORWAY

NTCINFOS.AS

Ostensjocexen is

O. Bax 65/2 Enessad

Fax 116093807569

GREECE

Liwarine Kandfomant $5 . A$

Stadiout 28
10562 thens

Tel (iof) 32.55327

\section{HONC KONC}

Sirindon Book Co. Lit

Astoria Bidg. 35

34 Asble Road Tsimshatsui

osors Oslo 6 . Norata

(e) 122197.45 .00

PAKISTAN

Mirza Book Agenor

5 Shabrab Quadid E-Azam

Fint $22,97.5 \%$

\section{HUNGARY}

Euro $\operatorname{lnf}$ S Senvice

Marziszipet, Eumipa Haz Fax (t) 117.60 .67

ICELAND

CELAND

wat Mog Henning

Lamgaregi is Postboff 392 Tet 1115524240

121 Reykartib Fax (1) 5623523

\section{INDIA}

Oxford Bente and Stationery Co

Scindia House

Calcutra 7 7age

Feliri1) 331.58965308

\section{INDONESIA}

Pdii-Lipt

PO. Bax 1298
Jakana 12042

-

abore 54000

Tel $(12) 735,36,0)$

PHILIPPINES

Aternational Boobsoteree Center in

Rin 179920 Citsland to Condo Totrer -

Wh dela Casta ext cor

Tet. 163248179060

POLAND

ARS Polona

12-050 Warsauxy

Kralknowive Praedinieacie ?

Tel. 122$) 264760$

PORTUGAL

\section{Licraria Portinge}

a do Carmo 70-7

Apart. 2681

Tel: $(01) 347.49 .825$

\section{SINGAPORE}

Ashgate Publishing

4t. Kallang Pudding Bond bo $04.03 \quad$ Tel 7415166 Singapore 1334

Fax (21) 57334.67

\section{IRELAND}

Government Supphies Agercy

Protacations Section.

15 Harct
Dubint 2

Teit 60131.11

\section{ISRAEL}

Praedicta

5 Shather Stree

P.O. Bar 31030
ferisalem 91430

Te. (2) 52879001

Fax $\{21528193$

\section{SPAIN}

Itund-Prensa Libros S.A.

Castello 37 . Apurtado 122

Mundi-Prensa Barcelona

Conseil de Cent to 301

Librera de la Generalis

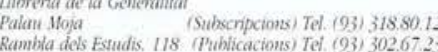

\begin{tabular}{|c|c|}
\hline $\begin{array}{l}\text { SRI LANKA } \\
\text { Centre for Policy Researd } \\
\text { co Colombo Agencies Lid } \\
\text { No. } 300.304 \text {. Gallo Road } \\
\text { Colontio } 3\end{array}$ & $\begin{array}{l}\text { To. (1) } 574240.573551-2 \\
\text { Fax (I) } 575394,510711\end{array}$ \\
\hline \multicolumn{2}{|l|}{ SWEDEN } \\
\hline $\begin{array}{l}\text { CE Fritzes AB } \\
S-10647 \text { Stockbolmi }\end{array}$ & $\begin{array}{l}\text { Tel. (a8) } 690.9090 \\
\text { Fav (as) } 20.5021\end{array}$ \\
\hline $\begin{array}{l}\text { Subscription Agenci: } \\
\text { 1Fimerngren-Williams bifo AB } \\
\text { PO. Bor } 1305 \\
17125 \text { Solna }\end{array}$ & $\begin{array}{l}\text { Td. }(08) 705.9750 \\
\text { Fax } 108) 27.0071\end{array}$ \\
\hline 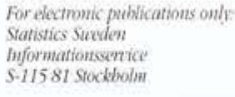 & $\begin{array}{l}\text { Td. las) } 783.5066 \\
\text { Fax (08) } 783.4045\end{array}$ \\
\hline $\begin{array}{l}\text { SWITZERLAND } \\
\text { Maditec S.A. Bools and Penod } \\
\text { Chemin des Palettes } 4 \\
\text { case postale 266 } \\
1020 \text { Remenis ID I }\end{array}$ & $\begin{array}{r}\text { Tel. }(021) 635.08 .65 \\
\text { Fax } 1021) 635.07 .80\end{array}$ \\
\hline $\begin{array}{l}\text { Lithrante Payot SA. } \\
\text { 4. place Peipinet } \\
\text { CP } 3212 \\
1002 \text { Lausanne }\end{array}$ & $\begin{array}{r}\text { Tel. } 1021) 320.25 .11 \\
\text { Fax }(021), 320.25 .14\end{array}$ \\
\hline $\begin{array}{l}\text { Libraine Lnilizes } \\
6 . \text { nee de Candalle } \\
\text { I205 Genere }\end{array}$ & $\begin{array}{l}\text { Tel. }(022) 320.26 .23 \\
\text { fax }:(022) 32973.18\end{array}$ \\
\hline $\begin{array}{l}\text { Subscription Agengy } \\
\text { Dynapresse larketing SA } \\
\text { is aueme liben } \\
\text { 1227 Carouge }\end{array}$ & $\begin{array}{l}\text { Tel: }(022), 308.08 .70 \\
F a x=(022), 308.07 .99\end{array}$ \\
\hline $\begin{array}{l}\text { OECD Boun Centre } \\
\text { Atroust-Bedhel-Allec } 6 \\
D-53175 \text { Bom (Germany) }\end{array}$ & $\begin{array}{r}\text { Tel } 10228), 959120 \\
\text { Fax } 10228,959.12 .17\end{array}$ \\
\hline
\end{tabular}

THAILAND

Suksit Siam Co. Lud.

113. 115 Fiumg Nabion Re

Opp. Wat Rajobitle

Tel $(662) 2259531 / 2$

\section{TRINIDAD \& TOBACO}

SSL Sistematics Studies Limites

9 wath Stree'

Trinidad E Tohago ws

Tel $(1809) 6453475$
Far 11890$), 6625654$

\section{TUNISIA}

Grande Lith
Fendri Ali

cosin ali

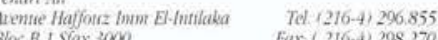
$2 x+30 x=$

TURKEY

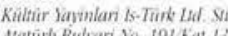

$0668 \mathrm{~K}$ Kacablidere Ankara Te. (312) $428.11,40$ ES 2458 Fax $(312)+117.24 .90$
and $425.0750 .51 / 5253$

Dolmababce Cad to 29

Te. $(212) 260.71 .88$

Besilbas Istanind

\section{UNITED KINCDOM}

HMSO

Posial arders onfy:

PO. Bax 276, Londont 5118 5DT

General enquiries

HUSO Boolshop

9 High Holhorn. London 1 TCIV GHB Bnandbes in: Beffast. Birmingbam. Bristol, Edinburgh
Subsription to OFCD periodicals mav a vo be placed throwgh main sibscription agencies

Orders and inquiries from countries shere distributos bave not vet been appoimed stould be sent to: OECD Publications Service. के 2 rue Andre.pascal, 75775 Paris Ceder 16. France 


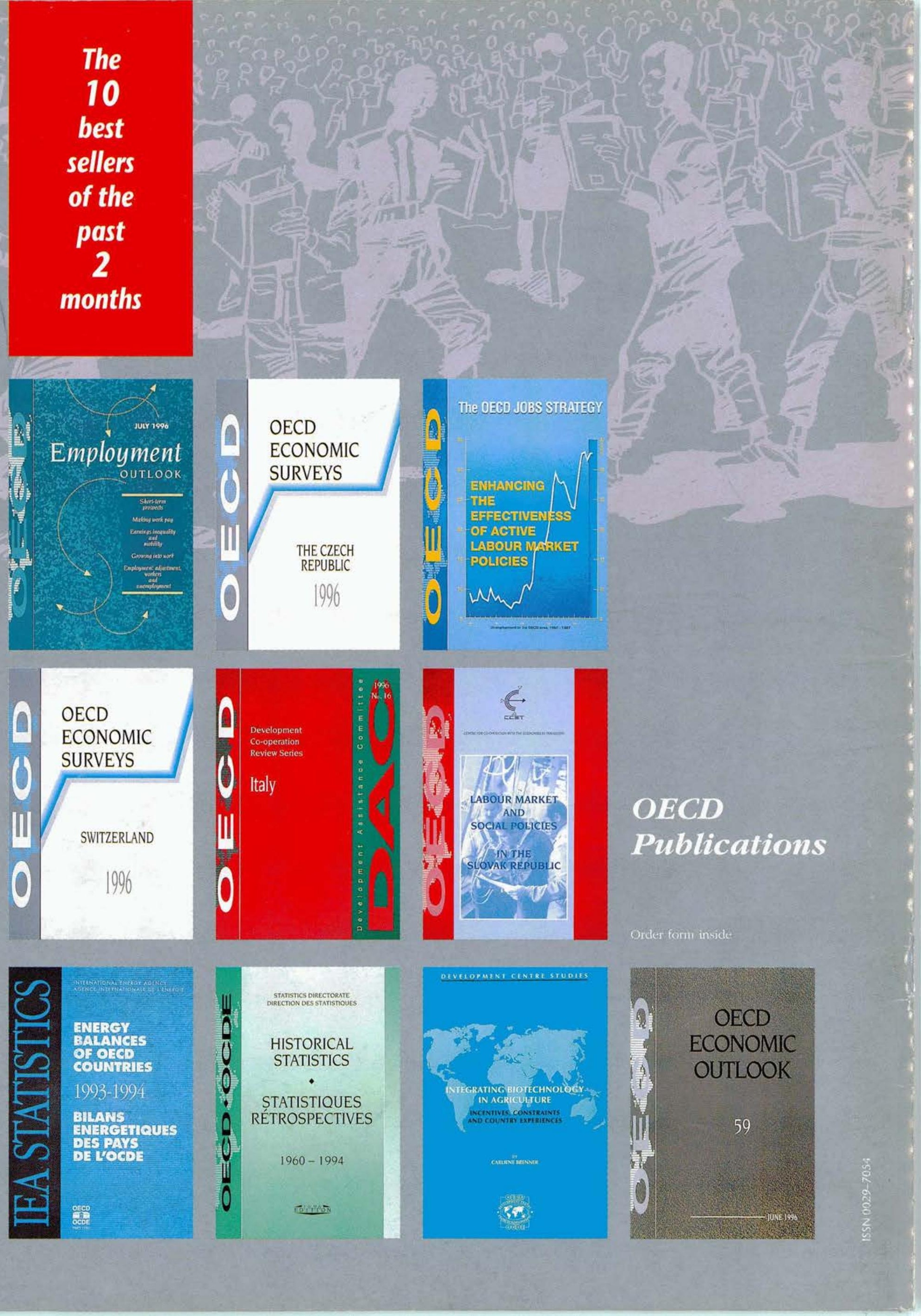

